\title{
Building Functionalized Peptidomimetics: The Use of Electroauxiliaries for Introducing N-Acyliminium Ions Into Peptides
}

\author{
Haizhou Sun, Connor Martin, David Kesselring, Rebecca Keller, and Kevin D. Moeller* \\ Department of Chemistry, Washington University, St. Louis, MO 63130 \\ moeller@wustl.edu
}

\section{SUPPLEMENTARY MATERIAL}

\section{General Information}

All proton magnetic resonance spectra were recorded using a Varian Mercury 300, Varian Unity 300 , or a Varian Inova 500 spectrometer with $\mathrm{CDCl}_{3}$ as solvent. Chemical shifts for proton spectra are reported as parts per million (ppm) downfield from tetramethysilane (TMS) in $\delta$ units, and coupling constants have been reported in cycles per second (hertz, Hz). The splitting patterns are designated as follows: $\mathrm{s}$ for singlet or br s for a broad singlet, $\mathrm{d}$ for doublet or br $\mathrm{d}$ for a broad doublet, $\mathrm{t}$ for triplet, $\mathrm{q}$ for quartet, and $\mathrm{m}$ for multiplet. ${ }^{13} \mathrm{C}$ NMR spectra are fully decoupled and were obtained using a Varian Mercury 300 at $75 \mathrm{MHz}$ or a Varian Inova 500 at $125 \mathrm{MHz}$. Chemical shifts are reported in ppm with the central line of the chloroform-d triplet referenced by $77.23 \mathrm{ppm}$. Infrared spectra (IR) were obtained from neat samples on $\mathrm{NaCl}$ plates using a Perkin Elmer Spectrum BS FT-IR System spectrophotometer. Nominal mass (referred to below as LR) spectral data were obtained using the first two sectors of a Micromass ZAB-T spectrometer with an $8 \mathrm{keV}$ acceleration voltage and resolving power of 1000 . Accurate mass (referred to below as HR) electron ionization (EI) mass spectral data were obtained using a Micromass ZAB-T spectrometer with an $8 \mathrm{keV}$ acceleration voltage, resolving power of at least 7000, an internal mass standard of polyfluorinated kerosene (PFK), and were acquired by magnet scan. Accurate mass (HR) fast atom bombardment (FAB) mass spectral data were obtained using a Kratos MS-50 spectrometer operated at a resolving power of at least 7000 with an external calibration compound of glycerol/lithium, a 3-nitrobenzylalcohol/lithium matrix, and were acquired by peak match.

HPLC data were obtained using a Helwett-Packard 1100 Series HPLC system equipped with a quaternary pump, variable wavelength detector, HP Chemstation software, and a Discovery HS C18 HPLC column $(25 \mathrm{~cm} \times 4.6 \mathrm{~mm} \times 5 \mu \mathrm{m})$ with a $2 \mu \mathrm{m}$ precolumn filter. The HPLC solvents used were isopropanol (IPA), acetonitrile, and water. All solvents were HPLC grade and purchased from either Sigma-Aldrich or EDM. Before use, solvents were sonicated and sparged with Argon. Sample injection volumes were $20 \mu \mathrm{L}$, and analytes were either dissolved or co-dissolved in IPA. All elutions were isocratic and run at ambient temperatures with a flow rate of $1 \mathrm{~mL} /$ minute. Analytes were detected at $254 \mathrm{~nm}$. Solvent systems are indicated on HPLC chromatograms.

Reactions were monitored by TLC with general-purpose silica gel coated glass plates purchased from Sigma-Aldrich Chemical Co. All preparative chromatography was flash chromatography and was carried out using ICN SiliTech 32-63D/60A silica gel. The solvents used for chromatography were mixed by volume and are reported for each experiment.

All electrolyses were accomplished using either a model 630 coulometer, a model 420A power supply, and a model 410 potentiostat available from Electrolytica or an Arbin Power supply equipped with MITS'97 software. Reactions were carried out at ambient temperature under untreated air unless otherwise indicated. Two carbon electrodes with Reticulated Vitreous Carbon (RVC) on the anode were used for all electrolyses. Carbon electrodes and RVC were purchased from Electrolytica, Inc. Tetrabutylammonium tetrafluoroborate was used as the electrolyte for all electrolyses and was purchased from Aldrich Chemical Co.

Chemical reagents and solvents were purchased from Aldrich Chemical Co., Sigma Chemical Co., Fluka, and Acros Organics and used without further purification unless otherwise noted. 
Dichloromethane was distilled over calcium hydride. Chloroform-d was purchased from Cambridge Isotope Laboratories or Aldrich Chemical Co. and used without further purification.

The purity of all compounds was determined by proton NMR and/or reverse phase HPLC data.

\section{General procedure for preparative electrochemical amide oxidations with silylated peptide derivatives in methanol:}

An oven-dried three-neck $100 \mathrm{~mL}$ round bottom flask was fitted with a Pt wire cathode, a RVC anode, and a rubber septum. A syringe needle was pushed through the septum and used as a nitrogen inlet. The flask was charged with the silylated dipeptide substrate $(0.5 \mathrm{mmol})$, anhydrous $\mathrm{MeOH}(16.7$ $\mathrm{mL})$, and tetrabutylammonium tetrafluroborate $(0.5 \mathrm{mmol})$. The reaction mixture was degassed by sonication while a slow stream of nitrogen was passed through the solution for $10 \mathrm{~min}$. The mixture was then electrolyzed at a constant current of $21.0 \mathrm{~mA}$ until $2.1-2.3 \mathrm{~F} / \mathrm{mol}$ had been passed. When complete, the $\mathrm{MeOH}$ was removed under reduced pressure and the crude product chromatographed through silica gel.

\section{General procedure for deprotection of Boc protecting groups:}

The Boc protected amino acid substrate $(2 \mathrm{mmol})$ was dissolved in ethyl acetate $(15 \mathrm{~mL})$ in a 50 $\mathrm{mL}$ round bottom flask and treated with a saturated aqueous $\mathrm{HCl}$ solution $(5 \mathrm{~mL})$. The reaction mixture was allowed to stir at room temperature for $30 \mathrm{~min}$, and then the solvent removed under reduced pressure. After most of the solvent was removed benzene was added to the mixture and then the pressure reduced again in order to remove any remaining water. The crude amine was left on the vacuum line for at least 8 $\mathrm{h}$ and then used without purification for the following step.

\section{General procedure for deprotection of $\mathrm{Cbz}$ protecting group:}

A $250 \mathrm{~mL}$ round bottom flask was charged with the $\mathrm{Cbz}$ protected amino acid substrate (2.0 mmol), palladium hydroxide $(10 \% \mathrm{w} / \mathrm{w})$, and methanol $(15 \mathrm{~mL})$. A balloon full of hydrogen gas was attached to the flask using a needle through a rubber septum. The mixture was vigorously stirred at room temperature for $12 \mathrm{~h}$ and then filtered through a short plug of celite. The filtrate was concentrated in vacuo and used without purification for the next reaction.

\section{General procedure for the hydrolysis of amino acid methyl esters:}

A $250 \mathrm{~mL}$ round bottom flask was charged with the amino acid methyl ester $(2.0 \mathrm{mmol}), \mathrm{MeOH}$ $(22.5 \mathrm{~mL})$, and water $(7.5 \mathrm{~mL})$. Lithium hydroxide $(168 \mathrm{mg}, 4.0 \mathrm{mmol})$ was added at $0{ }^{\circ} \mathrm{C}$, and the reaction was allowed to stir for $3 \mathrm{~h}$ at $0{ }^{\circ} \mathrm{C}$ followed by an additional $12 \mathrm{~h}$ at room temperature. The mixture was concentrated under reduced pressure and the remaining aqueous solution was acidified until the $\mathrm{pH}$ reached $\sim 2.0$. The aqueous solution was then extracted three times with ethyl acetate. The combined EtOAc layers were dried over $\mathrm{MgSO}_{4}$ and concentrated in vacuo. The crude product could be further purified using a silica gel column or used directly for the following step.

\section{General procedure for preparation of phenyldimethylsilyl lithium:}

Lithium wire ( $1 \%$ sodium) $(0.5 \mathrm{~g}, 72 \mathrm{mmol})$ was washed two times with dry hexane, cut into small slices in the hexane, and then quickly transferred under argon atmosphere (using an inverted argon funnel) to a flame-dried $100 \mathrm{~mL}$ round bottom flask containing dry THF $(20 \mathrm{~mL})$. Chlorodimethylphenylsilane $(5 \mathrm{~mL}, 29.8 \mathrm{mmol})$ was added slowly to this mixture at room temperature. The reaction was then sonicated in order to activate the lithium and initiate the reaction which led to a dark red solution. The reaction mixture was allowed to stir at room temperature for $12 \mathrm{~h}$. The resulting silyl lithium solution can be used immediately or stored under argon at $0{ }^{\circ} \mathrm{C}$ for one to two weeks.

\section{2-Methoxymethylpyrrolidine-1-carboxylic acid tert-butyl ester:}

In an oven-dried $250 \mathrm{~mL}$ round bottom flask was added L-prolinol $(3.51 \mathrm{~g}, 34.7 \mathrm{mmol})$ and dry ethyl acetate $(25 \mathrm{~mL})$ under nitrogen. The solution was cooled to $0{ }^{\circ} \mathrm{C}$ using an ice bath. While stirring, 
$(\mathrm{Boc})_{2} \mathrm{O}(6.48 \mathrm{~g}, 29.6 \mathrm{mmol})$ was added. The mixture was allowed to warm to room temperature and stirred for $90 \mathrm{~min}$. The reaction was quenched with $25 \mathrm{~mL}$ of $1 \mathrm{~N} \mathrm{HCl}$ solution and transferred to a separatory funnel. The reaction mixture was washed with $1 \mathrm{~N} \mathrm{HCl}$ solution $(2 \mathrm{X} 25 \mathrm{~mL})$, brine $(2$ X 25 $\mathrm{mL}$ ) and the combined organic layers then dried over $\mathrm{MgSO}_{4}$. After filtration, the filtrate was concentrated in vacuo and used without further purification for the following step.

To a solution of the crude N-(tert-butoxycarbonyl)-L-prolinol $(7.28 \mathrm{~g}, \sim 34 \mathrm{mmol})$ in DMF (60 $\mathrm{mL})$ at room temperature were added methyl iodide $(4.42 \mathrm{~mL}, 70 \mathrm{mmol})$ and potassium hydroxide $(8 \mathrm{~g}$, $137 \mathrm{mmol})$. The obtained suspension was allowed to stir for $12 \mathrm{~h}$ and methyl iodide $(2.2 \mathrm{~mL}, 35 \mathrm{mmol})$ and potassium hydroxide $(4 \mathrm{~g}, 68 \mathrm{mmol})$ were added. The reaction was stirred for an additional $8 \mathrm{~h}$ and then the reaction mixture quenched with $125 \mathrm{~mL}$ of $\mathrm{H}_{2} \mathrm{O}$. The mixture was washed with ethyl acetate (3 $\mathrm{X} 40 \mathrm{~mL}$ ) and the combined organic layers dried over $\mathrm{MgSO}_{4}$. After filtration, the filtrate was concentrated in vacuo. The resulting residue was chromatographed through silica gel (slurry packed with hexane and eluted with 1:4 EtOAc/hexane) and the desired product (5.51 g) was obtained as colorless oil in a 74\% yield over two steps. The spectroscopic data for the product were consistent with those previously reported in the literature (Katoh, T.; Nagata, Y.; Kobayashi, Y.; Arai, K.; Minami, J.; Terashima, S. Tetrahedron 1994, 50, 6221).

\section{2-Methoxy-5-methoxymethylpyrrolidine-1-carboxylic acid tert-butyl ester:}

An oven-dried three-neck $100 \mathrm{~mL}$ round bottom flask was charged with the protected L-prolinol methyl ether $(1.52 \mathrm{~g}, 7.0 \mathrm{mmol}), \mathrm{MeOH}(14.1 \mathrm{~mL})$, and tetraethylammonium tosylate $(127 \mathrm{mg}, 0.42$ $\mathrm{mmol}$ ). The flask was equipped with a carbon rod anode, a platinum wire cathode, and a nitrogen inlet. The reaction mixture was degassed by sonication while a slow stream of nitrogen that was passed through the solution for $5 \mathrm{~min}$. The mixture was then electrolyzed at a constant current of $26.8 \mathrm{~mA}$ until 2.1 $\mathrm{F} / \mathrm{mol}$ had been passed. When complete, the $\mathrm{MeOH}$ was removed under reduced pressure and the crude oil chromatographed through silica gel using a gradient elution from 1:5 EtOAc/hexane to 1:3 EtOAc/hexane. The column afforded $1.25 \mathrm{~g}(72 \%)$ desired methoxylated amide as a mixture of two diastereomers. The yield of this reaction was determined using GC-MS because the product isolated from the column was always a mixture of the desired methoxylated prolinol derivative and the starting material. The GC-MS was used to determine the ratio of product to starting material which usually ranged from $6: 1$ to $3: 1$. The yield reported represents the best yield obtained for the reaction.

\section{2-(Dimethylphenylsilyl)-5-methoxymethylpyrrolidine-1-carboxylic acid tert-butyl ester (12b):}

A THF solution of lithium dimethylphenylsilane $(<29.8 \mathrm{mmol}, \sim 20 \mathrm{~mL})$ was prepared according to the general procedure outlined above. The volume of THF was then reduced in vacuo (about $75 \%$ of the THF was removed), and dry ether $(20 \mathrm{~mL})$ was added. The silyl lithium solution in ether/THF was transferred into a flame-dried $100 \mathrm{~mL}$ round bottom flask charged with copper cyanide $(900 \mathrm{mg}, 10$ $\mathrm{mmol})$ and dry ether $(10 \mathrm{~mL})$. The mixture was dark black in color. After stirring at room temperature for $10 \mathrm{~min}$, the reaction mixture was cooled to $-40{ }^{\circ} \mathrm{C}$ and stirred for another $25 \mathrm{~min}$. At the same time, the methoxylate prolinol substrate $(1.54 \mathrm{~g}, 6.3 \mathrm{mmol})$ was added to a flame-dried $250 \mathrm{~mL}$ round bottom flask and dissolved in $5 \mathrm{~mL}$ of ether. The prepared silyl cuprate solution was then transferred into the flask containing the substrate by cannulation under argon. To this mixture was added $\mathrm{BF}_{3} \mathrm{Et}_{2} \mathrm{O}(0.5 \mathrm{~mL}$, $3.9 \mathrm{mmol})$ at $-40{ }^{\circ} \mathrm{C}$. The reaction was stirred for $3 \mathrm{~h}$ at $-40{ }^{\circ} \mathrm{C}$ and then allowed to warm to room temperature and quenched with a $1: 1 \mathrm{NH}_{3} \cdot \mathrm{H}_{2} \mathrm{O} / \mathrm{NH}_{4} \mathrm{Cl}$ buffer solution. The resulting mixture was stirring for 30 min until a bright blue color appeared and then transferred to a separatory funnel. The layers were separated and the aqueous layer was extracted with ether. The organic layers were combined, dried over $\mathrm{MgSO}_{4}$, and concentrated in vacuo. The crude product was chromatographed through silica gel using a gradient elution from 1:20 EtOAc/hexane to 1:6 EtOAc/hexane as eluant to afford $1.34 \mathrm{~g}(61 \%)$ of the product. ${ }^{1} \mathrm{H} \mathrm{NMR}\left(\mathrm{CDCl}_{3} / 300 \mathrm{MHz}\right)$ (mixture of two diastereomers with approximately $2: 1$ ratio and their rotamers observed) $\delta 7.61-7.50(\mathrm{~m}, 2 \mathrm{H}), 7.34-7.24(\mathrm{~m}, 3 \mathrm{H}), 3.84(\mathrm{br} \mathrm{s}, 0.33 \mathrm{H}), 3.72(\mathrm{br} \mathrm{s}, 0.67 \mathrm{H}), 3.64(\mathrm{~d}$, $\mathrm{J}=6.6 \mathrm{~Hz}, 0.33 \mathrm{H}), 3.56(\mathrm{~d}, \mathrm{~J}=9.9 \mathrm{~Hz}, 0.33 \mathrm{H}), 3.49(\mathrm{dd}, \mathrm{J}=9.0,3.0 \mathrm{~Hz}, 0.67 \mathrm{H}), 3.42(\mathrm{dd}, \mathrm{J}=9.4,3.4 \mathrm{~Hz}$, 
$0.67 \mathrm{H}), 3.31(\mathrm{~s}, 3 \mathrm{H}), 3.18(\mathrm{t}, \mathrm{J}=8.8 \mathrm{~Hz}, 1 \mathrm{H}), 2.17-1.61(\mathrm{~m}, 4 \mathrm{H}), 1.44$ and 1.38 (s and s, 9H), 0.40 and 0.38 (s and s, $6 \mathrm{H}) ;{ }^{13} \mathrm{C}$ NMR $\left(\mathrm{CDCl}_{3} / 75 \mathrm{MHz}\right) \delta 154.3,139.0,134.4,134.2,134.0,132.9,129.0,128.5,128.0$, $127.8,79.1,78.8,73.6,72.1,59.2,59.0,56.9,56.7,49.0,29.3,28.8,28 ., 4,27.1,26.2,-1.7,-2.4,-2.8$, 3.2, -3.7; IR (neat/NaCl) 3069, 2974, 1693, 1392, 1247, 1175, 1112, 821, 736, $702 \mathrm{~cm}^{-1}$; LRFAB MS (relative intensity) $\mathrm{m} / \mathrm{z} 356$ (2) $\mathrm{MLi}^{+}, 313$ (23) $\mathrm{MLi}^{+}-\mathrm{C}_{2} \mathrm{H}_{4} \mathrm{O}+\mathrm{H}^{+}, 160$ (100); HRFAB MS m/z calculated for $[\mathrm{M}+\mathrm{Li}]^{+}$356.2233, found 356.2224.

\section{\{1-Benzyl-2-[2-(dimethylphenylsilyl)-5-methoxymethylpyrrolidin-1-yl]-2-oxo-ethyl\}-carbamic acid tert-butyl ester (13):}

The t-Boc protected silylated prolinol substrate $(0.94 \mathrm{~g}, 2.2 \mathrm{mmol})$ was deprotected using the general procedure described above and then the amine carried into the coupling reaction. A $250 \mathrm{~mL}$ oven-dried round bottom flask was charged with the amine substrate obtained in the above step and 15 $\mathrm{mL}$ of dry dichloromethane. The mixture was treated with $0.61 \mathrm{~mL}$ of triethylamine. The solution was stirred at room temperature for $15 \mathrm{~min}$ and then DCC (1.14 g, $5.5 \mathrm{mmol})$, HOBT (0.6 g, $4.4 \mathrm{mmol})$, and phenylalanine methyl ester $(1.17 \mathrm{~g}, 4.4 \mathrm{mmol})$ were added in sequence. The reaction mixture was allowed to stir for $16 \mathrm{~h}$ at room temperature. The reaction was then quenched with water and the layers were separated in a separatory funnel. The aqueous layer was washed with dichloromethane three times and the combined organic layers were washed with brine twice before being dried over $\mathrm{MgSO}_{4}$. After filtration, the filtrate was concentrated under reduced pressure. The crude product was chromatographed through silica gel using a gradient elution from 1:7 EtOAc/hexane to 1:2 EtOAc/hexane as eluant to afford $1.26 \mathrm{~g}(61 \%)$ of the product. ${ }^{1} \mathrm{H}$ NMR $\left(\mathrm{CDCl}_{3} / 300 \mathrm{MHz}\right)$ (mixture of two diastereomers with approximately $1: 1$ ratio and their rotamers were observed) $\delta 7.57-7.41(\mathrm{~m}, 2 \mathrm{H}), 7.40-7.09(\mathrm{~m}, 7 \mathrm{H}), 7.05$ $7.02(\mathrm{~m}, 1 \mathrm{H}), 5.50(\mathrm{~d}, \mathrm{~J}=7.8 \mathrm{~Hz}, 0.03 \mathrm{H}), 5.27(\mathrm{dd}, \mathrm{J}=8.7,6.0 \mathrm{~Hz}, 0.97 \mathrm{H}), 4.82-4.45(\mathrm{~m}, 1.5 \mathrm{H}$, peaks in 4.69 $(\mathrm{dd}, \mathrm{J}=16.4,7.6 \mathrm{~Hz})$ and $4.59(\mathrm{td}, \mathrm{J}=9.3,5.4 \mathrm{~Hz})$ represent two main isomers), 3.60-3.45 (m, 0.4H), 3.48$3.46(\mathrm{~m}, 0.1 \mathrm{H}), 3.34-3.00(\mathrm{~m}, 2 \mathrm{H}), 3.28,3.22,3.12$ and $3.07(\mathrm{~s}, \mathrm{~s}, \mathrm{~s}$ and $\mathrm{s}, 3 \mathrm{H}), 2.97-2.74(\mathrm{~m}, 2 \mathrm{H}), 2.67-$ $2.52(\mathrm{~m}, 1 \mathrm{H}), 1.81-1.16(\mathrm{~m}, 3.5 \mathrm{H}), 1.41,1.38,1.36,1.30$ and $1.29(\mathrm{~s}, \mathrm{~s}, \mathrm{~s}, \mathrm{~s}$ and $\mathrm{s}, 9 \mathrm{H}), 0.88-0.76(\mathrm{~m}$, $0.5 \mathrm{H}), 0.42,0.36,0.350 .32,0.28,0.27$ (s, s, s, s, s and s, $6 \mathrm{H}) ;{ }^{13} \mathrm{C} \mathrm{NMR}\left(\mathrm{CDCl}_{3} / 75 \mathrm{MHz}\right) \delta 170.3,170.0$, 155.0, 154.8, 139.2, 137.3, 137.1, 136.3, 134.5, 134.2, 134.0, 130.0, 129.9, 129.6, 129.2, 128.6, 128.6, $128.3,127.9,127.1,126.9,79.4,79.4,74.0,71.2,59.3,59.0,57.8,57.2,55.2,53.5,50.7,49.0,41.7,40.8$, 28.9, 28.7, 28.6, 27.5, 26.6, 26.2, -0.7, -1.0, -2.4, -3.3, -3.6; IR (neat/NaCl) 3428, 3286, 2972, 1704, 1624, $1495,1448,1248,1169,1111,828,735,700 \mathrm{~cm}^{-1}$; LRFAB MS (relative intensity) m/z 503 (75) $\mathrm{MLi}^{+}$, 403 (90) $\mathrm{MLi}^{+}-\mathrm{Boc}+\mathrm{H}^{+}, 294$ (30), 160 (100); HRFAB MS m/z calculated for $[\mathrm{M}+\mathrm{Li}]^{+}$503.2917, found 503.2898 .

\section{[1-Benzyl-2-(2-methoxy-5-methoxymethylpyrrolidin-1-yl)-2-oxoethyl]-carbamic acid tert-butyl ester (14):}

The silylated dipeptide substrate $(189 \mathrm{mg}, 0.38 \mathrm{mmol}$ ) was oxidized using the general procedure outlined above. For this experiment $2.3 \mathrm{~F} / \mathrm{mol}$ of current was passed. The crude product was chromatographed through silica gel using a gradient elution from 1:5 EtOAc/hexane to 1:3 EtOAc/hexane. The column afforded $116 \mathrm{mg}(78 \%)$ of the desired product along with $26 \mathrm{mg}(14 \%)$ of recovered starting material. ${ }^{1} \mathrm{H}$ NMR $\left(\mathrm{CDCl}_{3} / 300 \mathrm{MHz}\right)$ (mixture of two diastereomers with approximately 2:1 ratio and their rotamers observed) $\delta 7.28-7.10(\mathrm{~m}, 5 \mathrm{H}), 5.39-5.34(\mathrm{~m}, 0.5 \mathrm{H}), 5.35(\mathrm{~d}$, $\mathrm{J}=5.1 \mathrm{~Hz}, 0.67 \mathrm{H}), 5.12(\mathrm{~d}, \mathrm{~J}=9.3 \mathrm{~Hz}, 0.33 \mathrm{H}), 4.94-4.86(\mathrm{~m}, 0.5 \mathrm{H}), 4.68-4.53(\mathrm{~m}, 0.67 \mathrm{H}), 4.27-4.14(\mathrm{~m}$, $0.67 \mathrm{H}), 3.80-3.75(\mathrm{~m}, 0.33 \mathrm{H}), 3.65(\mathrm{dd}, \mathrm{J}=8.8,4.0 \mathrm{~Hz}, 0.33 \mathrm{H}), 3.42-3.04(\mathrm{~m}, 3 \mathrm{H}), 3.34,3.34,3.31,3.29$, 3.28, 3.18 and 3.17 (s, s, s, s, s, s and s, 6H), 2.97-2.79 (m, 1H), 2.09-1.62 (m, 4H), 1.48, 1.44, 1.41 and $1.34(\mathrm{~s}, \mathrm{~s}, \mathrm{~s}$ and $\mathrm{s}, 9 \mathrm{H}) ;{ }^{13} \mathrm{C} \mathrm{NMR}\left(\mathrm{CDCl}_{3} / 75 \mathrm{MHz}\right) \delta 172.8,172.6,172.1,155.4,155.0,137.1,137.0$, $136.7,129.9,129.8,129.8,129.7,128.7,128.6,127.2,1127.1,126.9,90.0,89.4,88.1,79.9,79.7,77.8$, 73.7, 71.5, 59.2, 59.1, 56.9, 56.8, 56.4, 56.0, 54.8, 54.1, 53.5, 53.2, 41.4, 39.6, 30.6, 30.2, 29.9, 28.9, 28.6, 28.5, 26.0, 24.3; IR (neat/NaCl) 2972, 1706, 1391, 1366, 1169, $1130 \mathrm{~cm}^{-1}$; LRFAB MS (relative 
intensity) m/z 399 (100) $\mathrm{MLi}^{+}, 299$ (94) $\mathrm{MLi}^{+}-\mathrm{Boc}+\mathrm{H}^{+}, 120$ (47); HRFAB MS m/z calculated for $[\mathrm{M}+\mathrm{Li}]^{+}$399.2471, found 399.2475.

\section{2-Benzyl-5-methoxymethyl-hexahydro-pyrrolo[1,2-a]imidazol-3-one (15):}

To an oven-dried $50 \mathrm{~mL}$ round bottom flask was added the methoxylated dipeptide substrate (165 $\mathrm{mg}, 0.42 \mathrm{mmol})$ and anhydrous ether $(15 \mathrm{~mL})$ at $-78^{\circ} \mathrm{C}^{\circ} \mathrm{BF}_{3} \mathrm{Et}_{2} \mathrm{O}(50 \mu \mathrm{l}, 0.42 \mathrm{mmol})$ was added and the reaction mixture was allowed to stir at $-78{ }^{\circ} \mathrm{C}$ for 1 hour before it was allowed to warm up to room temperature over a $30 \mathrm{~min}$ period. The reaction was stopped and the solvent was removed in vacuo. The crude product was chromatographed through silica gel using a gradient elution from 1:4 EtOAc/hexane to 1:2 EtOAc/hexane. The column afforded $108 \mathrm{mg}(71 \%)$ of the desired cyclized product. ${ }^{1} \mathrm{H}$ NMR $\left(\mathrm{CDCl}_{3} / 300 \mathrm{MHz}\right) \delta 7.31-7.17(\mathrm{~m}, 5 \mathrm{H}), 4.81(\mathrm{dd}, \mathrm{J}=7.8,5.1 \mathrm{~Hz}, 1 \mathrm{H}), 4.12(\mathrm{dd}, \mathrm{J}=8.4,3.9 \mathrm{~Hz}, 1 \mathrm{H}), 4.01-$ $3.95(\mathrm{~m}, 1 \mathrm{H}), 3.43(\mathrm{~d}, \mathrm{~J}=4.6 \mathrm{~Hz}, 2 \mathrm{H}), 3.36(\mathrm{~s}, 3 \mathrm{H}), 3.16(\mathrm{dd}, \mathrm{J}=13.5,3.9,1 \mathrm{H}), 2.78(\mathrm{dd}, \mathrm{J}=13.8,8.7 \mathrm{~Hz}$, $1 \mathrm{H}), 2.18$ (br s, $1 \mathrm{H}), 2.11-1.82(\mathrm{~m}, 3 \mathrm{H}), 1.12-1.02(\mathrm{~m}, 1 \mathrm{H}) ;{ }^{13} \mathrm{C} \mathrm{NMR}\left(\mathrm{CDCl}_{3} / 75 \mathrm{MHz}\right) \delta 174.8,138.4$, 129.5, 128.3, 126.4 , 76.1, 74.1, 64.4, 59.1, 53.5, 38.8, 33.8, 28.0; IR (neat/NaCl) 3350, 2923, 1698, 1402, 1121, 750, $701 \mathrm{~cm}^{-1}$; LRFAB MS (relative intensity) m/z 267 (5) $\mathrm{MLi}^{+}, 219$ (7), 160 (100), 89 (28); HRFAB MS m/z calculated for $[\mathrm{M}+\mathrm{Li}]^{+} 267.1685$, found 267.1682 .

\{2-[2-(Dimethylphenylsilyl)-5-methoxymethylpyrrolidin-1-yl]-1-hydroxymethyl-2-oxoethyl\}carbamic acid tert-butyl ester (two main rotamers with approximately 3:1 ratio) (16):

Before the coupling reaction, the BOC protected silylated prolinol substrate $(0.768 \mathrm{~g}, 2.2 \mathrm{mmol})$ was deprotected using the general procedure outlined above.

A $250 \mathrm{~mL}$ round bottom flask was charged with $\mathrm{N}$-(tert-butoxycarbonyl)-serine $(452 \mathrm{mg}, 2.2$ $\mathrm{mmol}), \mathrm{N}$-methylmorpholine $(0.308 \mathrm{~mL}, 2.9 \mathrm{mmol})$, isobutylchloroformate $(0.285 \mathrm{~mL}, 2.2 \mathrm{mmol})$, and $\mathrm{CH}_{2} \mathrm{Cl}_{2}(36 \mathrm{~mL})$. The reaction mixture was stirred at $-15{ }^{\circ} \mathrm{C}$ for $25 \mathrm{~min}$. The silylated prolinol amine substrate (crude) dissolved in $\mathrm{CH}_{2} \mathrm{Cl}_{2}(6 \mathrm{~mL})$ was canulated into the above solution. Two additional washings with dichloromethane ensured complete transfer of the substrate. The reaction mixture was warmed up to room temperature and stirred for $12 \mathrm{~h}$. After the reaction was quenched with water and the layers were separated, the organic layer was washed with water $(3 \times 20 \mathrm{~mL})$ and dried over the $\mathrm{MgSO}_{4}$ After filtration, the filtrate was concentrated in vacuo. The residue was chromatographed through a silica gel column using an eluant of 1:1 Hexane/EtOAc to afford $668 \mathrm{mg}(70 \%)$ of the silated dipeptide product. ${ }^{1} \mathrm{H}$ NMR $\left(\mathrm{CDCl}_{3} / 300 \mathrm{MHz}\right) \delta$ 7.52-7.48 (m, 2H), 7.38-7.30 (m, 3H), $5.48(\mathrm{~d}, \mathrm{~J}=8.4 \mathrm{~Hz}, 1 \mathrm{H}), 4.64-4.60$ (m, $1 \mathrm{H}), 4.20-4.15(\mathrm{~m}, 1 \mathrm{H}), 3.70-3.66(\mathrm{~m}, 2 \mathrm{H}), 3.48-3.41(\mathrm{~m}, 2 \mathrm{H}), 3.20$ and 3.18 (s and s, $3 \mathrm{H}), 3.13-3.08(\mathrm{~m}$, $1 \mathrm{H}), 2.99-2.78(\mathrm{~m}, 1 \mathrm{H}), 1.87-1.66(\mathrm{~m}, 4 \mathrm{H}), 1.46(\mathrm{~s}, 9 \mathrm{H}), 0.40$ and $0.39(\mathrm{~s}$ and s, $9 \mathrm{H}) ;{ }^{13} \mathrm{C} \mathrm{NMR}\left(\mathrm{CDCl}_{3} / 75\right.$ MHz) $\delta 169.4,155.6,147.2,137.4,134.2,129.0,127.5,79.7,72.8,64.1,58.8,58.7,57.6,53.3,49.2$, $29.1,28.3,28.3,26.0,-2.8,-3.6$; IR (neat/NaCl) 3435, 2953, 1747, 1713, 1634, 1496, 1456, 1247, 1170, $855,735,702 \mathrm{~cm}^{-1}$; LRFAB MS (relative intensity) $\mathrm{m} / \mathrm{z} 443$ (97) $\mathrm{MLi}^{+}, 343$ (100) $\mathrm{MLi}^{+}-\mathrm{Boc}+\mathrm{H}, 256$ (30), 135 (50); HRFAB MS m/z calculated for [M+Li] 443.2554 , found 443.2548.

(6-Methoxymethyl-4-oxo-hexahydropyrrolo[2,1-b][1,3]oxazin-3-yl)-carbamic acid tert-butyl ester (17):

An oven-dried $50 \mathrm{~mL}$ three-neck round bottom flask was fitted with a Pt wire cathode, a RVC anode, and a septum. A syringe needle was pushed through the septum and used as a nitrogen inlet. The flask was charged with the silylated dipeptide substrate $(90 \mathrm{mg}, 0.21 \mathrm{mmol})$, anhydrous acetonitrile $(6.1$ $\mathrm{mL})$, isopropyl alcohol $(0.7 \mathrm{~mL})$, and tetrabutylammonium tetrafluroborate $(68 \mathrm{mg}, 0.21 \mathrm{mmol})$. The resulting mixture was degassed by sonication while a slow stream of nitrogen was passed through the solution for $10 \mathrm{~min}$. The mixture was then electrolyzed at a constant current of $21.0 \mathrm{~mA}$ until $2.2 \mathrm{~F} / \mathrm{mol}$ had been passed. When complete, the $\mathrm{MeOH}$ was removed under reduced pressure and the crude oil chromatographed through silica gel using a gradient elution from 1:3 EtOAc/hexane to 1:1 EtOAc/hexane. The column afforded $49 \mathrm{mg}(80 \%)$ of the desired product. ${ }^{1} \mathrm{H}$ NMR $\left(\mathrm{CDCl}_{3} / 300 \mathrm{MHz}\right) \delta$ 5.45 (br s, $1 \mathrm{H}), 5.14(\mathrm{t}, \mathrm{J}=6.0 \mathrm{~Hz}, 1 \mathrm{H}), 4.44-4.36(\mathrm{~m}, 1 \mathrm{H}), 4.11(\mathrm{td}, \mathrm{J}=4.5,3.3 \mathrm{~Hz}, 1 \mathrm{H}), 3.69$ (dd, J=9.2, 
$3.2 \mathrm{~Hz}, 1 \mathrm{H}), 3.57(\mathrm{dd}, \mathrm{J}=8.4,7.2 \mathrm{~Hz}, 1 \mathrm{H}), 3.49(\mathrm{dd}, \mathrm{J}=9.3,7.5 \mathrm{~Hz}, 1 \mathrm{H}), 3.35(\mathrm{~s}, 3 \mathrm{H}), 2.23-2.17(\mathrm{~m}, 1 \mathrm{H})$, 2.10-1.88(m, 3H), 1.44(s, 9H); ${ }^{13} \mathrm{C} \mathrm{NMR}\left(\mathrm{CDCl}_{3} / 75 \mathrm{MHz}\right) \delta 166.4,155.8,86.9,80.1,70.7,68.2,59.1$, 56.3, 49.2, 30.3, 28.2, 25.1; IR (neat/NaCl) 3326, 2979, 1717, 1680, 1440, 1169, 870, $771 \mathrm{~cm}^{-1}$; LRFAB MS (relative intensity) m/z 307 (21) $\mathrm{MLi}^{+}, 160$ (100); HRFAB MS m/z calculated for [M+Li] 307.1845 , found 307.1834 .

\section{5-Benzenesulfonylpyrrolidine-1,2-dicarboxylic acid 1-benzyl ester 2-methyl ester (18):}

To a $250 \mathrm{~mL}$ oven-dried round bottom flask was added the methoxylated substrate $(1.94 \mathrm{~g}, 6.6$ $\mathrm{mmol})$ synthesized above, the sodium salt of phenylsulfinic acid (2.95 g, $18 \mathrm{mmol})$, magnesium sulfate $(2.17 \mathrm{~g}, 18 \mathrm{mmol})$, and dichloromethane $(24 \mathrm{~mL})$. Trifluroacetic acid $(1.39 \mathrm{~mL} / 18 \mathrm{mmol})$ was added while the white suspension was stirring. The reaction was allowed to stir at room temperature for $2 \mathrm{~h}$ and then quenched with water. The mixture was transferred to a separatory funnel and extracted three times with dichloromethane. The combined organic layers were then washed with sat. sodium bicarbonate solution and brine, dried over $\mathrm{MgSO}_{4}$, and concentrated in vacuo. The crude product was run through a short column using an eluant of 4:2:1 hexane:EtOAc: $\mathrm{CH}_{2} \mathrm{Cl}_{2}$. The yellow product obtained was then recrystallized using hexane/ether. The product $(2.27 \mathrm{~g} / 85 \%)$ was obtained as a white solid. ${ }^{1} \mathrm{H}$ NMR $\left(\mathrm{CDCl}_{3} / 300 \mathrm{MHz}\right)$ (two main rotamers with approximately 1:1 ratio observed) $\delta 7.90(\mathrm{~d}, \mathrm{~J}=7.5 \mathrm{~Hz}, 1 \mathrm{H})$, $7.80(\mathrm{~d}, \mathrm{~J}=7.5,1 \mathrm{H}), 7.66-7.37(\mathrm{~m}, 3 \mathrm{H}), 7.36-7.27(\mathrm{~m}, 3 \mathrm{H}), 7.21-7.11(\mathrm{~m}, 2 \mathrm{H}), 5.32(\mathrm{~d}, \mathrm{~J}=7.8 \mathrm{~Hz}, 0.5 \mathrm{H})$, $5.22(\mathrm{~d}, \mathrm{~J}=7.8 \mathrm{~Hz}, 0.5 \mathrm{H}), 5.02\left(\mathrm{~A}\right.$ of $\left.\mathrm{AB}, \mathrm{J}_{\mathrm{A}^{\prime} \mathrm{B}}=12.6 \mathrm{~Hz}, 0.5 \mathrm{H}\right), 4.96\left(\mathrm{~A}\right.$ of $\left.\mathrm{AB}, \mathrm{J}_{\mathrm{AB}}=12.0 \mathrm{~Hz}, 0.5 \mathrm{H}\right), 4.81(\mathrm{~B}$ of $\left.\mathrm{AB}, \mathrm{J}_{\mathrm{AB}}=12.0 \mathrm{~Hz}, 0.5 \mathrm{H}\right), 4.58(\mathrm{~d}, \mathrm{~J}=8.7 \mathrm{~Hz}, 0.5 \mathrm{H}), 4.52(\mathrm{~d}, \mathrm{~J}=9.3 \mathrm{~Hz}, 0.5 \mathrm{H}), 4.17$ (B of $\mathrm{AB}$, $\left.\mathrm{J}_{\mathrm{A}^{\prime} \mathrm{B}}=12.3 \mathrm{~Hz}, 0.5 \mathrm{H}\right), 3.72$ and $3.47(\mathrm{~s}$ and $\mathrm{s}, 3 \mathrm{H}), 2.84-2.63(\mathrm{~m}, 2 \mathrm{H}), 2.43-2.26(\mathrm{~m}, 1 \mathrm{H}), 2.05-1.98(\mathrm{~m}$, $1 \mathrm{H}) ;{ }^{13} \mathrm{C} \mathrm{NMR}\left(\mathrm{CDCl}_{3} / 75 \mathrm{MHz}\right) \delta 172.6,172.4,154.1,153.9,137.7,137.6,135.6,135.3,134.2,134.1$, 129.4, 129.3, 129.2, 129.2, 128.6, 128.6, 128.5, 128.4, 128.0, 78.9, 78.6, 68.0, 68.0, 60.7, 60.5, 52.7, 52.4, 29.6, 28.3, 26.3, 25.2; IR (neat/NaCl) 3065, 2955, 1755, 1732, 1721, 1447, 1398, 1346, 1322, 1291, 1147 , 732, $690 \mathrm{~cm}^{-1}$; LRFAB MS (relative intensity) m/z 410 (38) $\mathrm{MLi}^{+}, 313$ (67), 218 (42), 160 (100); HRFAB MS m/z calculated for $[\mathrm{M}+\mathrm{Li}]^{+} 410.1250$, found 410.1254 .

\section{5-(Dimethylphenyl-silyl)-pyrrolidine-1,2-dicarboxylic acid 1-benzyl ester 2-methyl ester (19):}

A THF solution of lithium dimethylphenylsilane $(<29.8 \mathrm{mmol})$ was prepared according to the general procedure described above and then transferred into a flame-dried $100 \mathrm{~mL}$ round bottom flask charged with copper cyanide $(900 \mathrm{mg}, 10 \mathrm{mmol})$ and dry THF $(10 \mathrm{~mL})$ under argon. The mixture was dark black in color. After stirring at room temperature for $10 \mathrm{~min}$, the reaction mixture was cooled to -78 ${ }^{\circ} \mathrm{C}$ and stirred for another $30 \mathrm{~min}$. At the same time, the sulphonyl proline substrate $(3.15 \mathrm{~g}, 7.81 \mathrm{mmol})$ was added to a flame-dried $250 \mathrm{~mL}$ round bottom flask and dissolved in $20 \mathrm{~mL}$ ether. The substrate was then transferred to the prepared silyl cuprate solution by cannulation under argon and allowed to stir for $1.5 \mathrm{~h}$ at $-78{ }^{\circ} \mathrm{C}$. The reaction was allowed to warm to room temperature and quenched with a $1: 1$ $\mathrm{NH}_{3} \mathrm{H}_{2} \mathrm{O} / \mathrm{NH}_{4} \mathrm{Cl}$ buffer solution. The mixture was stirred for 30 min until a bright blue color showed up. The reaction was then transferred to a separatory funnel. The layers were separated and the aqueous layer was extracted with ether. The organic layers were combined, dried over $\mathrm{MgSO}_{4}$, and concentrated in vacuo. The crude product was chromatographed through silica gel using a gradient elution from 1:10 EtOAc/hexane to $1: 5 \mathrm{EtOAc} /$ hexane to afford $2.18 \mathrm{~g}(71 \%)$ of the product. ${ }^{1} \mathrm{H} \mathrm{NMR}\left(\mathrm{CDCl}_{3} / 300 \mathrm{MHz}\right)$ (two main rotamers with approximately $2: 1$ ratio observed) $\delta 7.61-7.26(\mathrm{~m}, 10 \mathrm{H}), 5.20(\mathrm{~A}$ of $\mathrm{AB}$, $\left.\mathrm{J}_{\mathrm{AB}}=12.3 \mathrm{~Hz}, 0.33 \mathrm{H}\right), 5.16\left(\mathrm{~A}\right.$ of $\left.\mathrm{AB}, \mathrm{J}_{\mathrm{A}^{\prime} \mathrm{B}}{ }^{\prime}=12.6 \mathrm{~Hz}, 0.67 \mathrm{H}\right), 5.01\left(\mathrm{~B}\right.$ of $\left.\mathrm{AB}, \mathrm{J}_{\mathrm{A}^{\prime} \mathrm{B}}{ }^{\prime}=12.3 \mathrm{~Hz}, 0.67 \mathrm{H}\right), 4.90(\mathrm{~B}$ of $\left.\mathrm{AB}, \mathrm{J}_{\mathrm{AB}}=12.0 \mathrm{~Hz}, 0.33 \mathrm{H}\right), 4.38(\mathrm{br}, 0.33 \mathrm{H}), 4.24(\mathrm{dd}, \mathrm{J}=6.6,4.2 \mathrm{~Hz}, 0.33 \mathrm{H}), 4.17(\mathrm{dd}, \mathrm{J}=8.2,3.8 \mathrm{~Hz}$, $0.34 \mathrm{H}), 3.78-3.55(\mathrm{~m}, 1 \mathrm{H}), 3.70$ and $3.47(\mathrm{~s}$ and $\mathrm{s}, 3 \mathrm{H}), 2.19-1.67(\mathrm{~m}, 4 \mathrm{H}), 0.44,0.400 .24$ and $0.23(\mathrm{~s}, \mathrm{~s}$, $\mathrm{s}$ and $\mathrm{s}, 6 \mathrm{H}) ;{ }^{13} \mathrm{C} \mathrm{NMR}\left(\mathrm{CDCl}_{3} / 75 \mathrm{MHz}\right) \delta 173.5,136.6,134.1,133.9,133.7,133.0,129.1,128.5,128.3$, $128.0,127.9,127.9,127.8,67.0,60.1,59.9,52.1,51.9,49.7,48.9,31.2,31.0,29.8,27.8,27.1,26.8,-2.8$, -3.6, -3.8, -4.0; IR (neat/NaCl) 2952, 1747, 1699, 1413, 1351, 1110, 834, $699 \mathrm{~cm}^{-1}$; LRFAB MS (relative intensity) $\mathrm{m} / \mathrm{z} 404$ (21) $\mathrm{MLi}^{+}, 313$ (58) $\mathrm{MLi}^{+}-\mathrm{PhCH}_{2}, 154$ (100); HRFAB MS m/z calculated for [M+Li] ${ }^{+}$ 404.1869, found 404.1852. 


\section{1-(2-tert-Butoxycarbonylamino-3-phenylpropionyl)-5-(dimethylphenylsilyl)-pyrrolidine-2- carboxylic acid methyl ester (20):}

Prior to the coupling reaction, the Cbz protected silylated proline substrate $(451 \mathrm{mg}, 1.71 \mathrm{mmol})$ was deprotected using the general procedure described above. To an oven dried $250 \mathrm{~mL}$ round bottom flask was added Boc protected phenylalanine $(531 \mathrm{mg}, 2 \mathrm{mmol})$, pyridine $(162 \mu \mathrm{L}, 2 \mathrm{mmol})$ and dry dicholomethane $(25 \mathrm{~mL})$ at $-15^{\circ} \mathrm{C}$. Cyanuric floride $(900 \mu \mathrm{L}, 10 \mathrm{mmol})$ was then added slowly and the mixture was stirred at $-15^{\circ} \mathrm{C}$ for 1 hour. The reaction was quenched with ice and the layers were separated. The organic layer was extracted with dichloromethane. The combined organic layers were dried over $\mathrm{MgSO}_{4}$ and concentrated in vacuo. The colorless crude was carried on to the next step without further purification.

A $250 \mathrm{~mL}$ round-bottom flask was charged with the acid fluoride prepared above and then charged with N-methylmorpholine $(770 \mu \mathrm{L}, 7 \mathrm{mmol})$ and dichloromethane $(30 \mathrm{~mL})$. A solution of the deprotected silylated proline in $10 \mathrm{~mL}$ dichlomethane was then added by cannulation to the flask under an argon atmosphere. The mixture was allowed to stir at room temperature for $12 \mathrm{~h}$ and then quenched with water. The layers were separated and the organic layer was extracted with dichloromethane. The combined organic layers were dried over $\mathrm{MgSO}_{4}$ and concentrated in vacuo. The crude product was chromatographed through silica gel using an eluant of 1:4 EtOAc/hexane to afford $470 \mathrm{mg}(54 \%)$ of the product. ${ }^{1} \mathrm{H} \mathrm{NMR}\left(\mathrm{CDCl}_{3} / 300 \mathrm{MHz}\right)$ (mixture of two diastereomers with approximately 2:1 ratio and their rotamers observed) $\delta 7.52-7.15(\mathrm{~m}, 10 \mathrm{H}), 5.46(\mathrm{~d}, \mathrm{~J}=8.1 \mathrm{~Hz}, 0.33 \mathrm{H}), 5.31(\mathrm{~d}, \mathrm{~J}=9.3 \mathrm{~Hz}, 0.67 \mathrm{H}), 4.53(\mathrm{dd}$, $\mathrm{J}=13.5,7.4 \mathrm{~Hz}, 0.33 \mathrm{H}), 4.36(\mathrm{dd}, \mathrm{J}=16.4,7.4 \mathrm{~Hz}, 0.67 \mathrm{H}), 4.14(\mathrm{~d}, \mathrm{~J}=9.3 \mathrm{~Hz}, 0.33 \mathrm{H}), 3.95(\mathrm{~d}, \mathrm{~J}=6.0 \mathrm{~Hz}$, $0.67 \mathrm{H}), 3.73$ and 3.70 (s and $\mathrm{s}, 3 \mathrm{H}), 3.07-2.70(\mathrm{~m}, 3 \mathrm{H}), 1.92-1.44(\mathrm{~m}, 4 \mathrm{H}), 1.40,1.34$ and $1.31(\mathrm{~s}, \mathrm{~s}$ and $\mathrm{s}$, $9 \mathrm{H}), 0.40,0.36,0.34,0.33,0.26(\mathrm{~s}, \mathrm{~s}, \mathrm{~s}, \mathrm{~s}$ and s, $6 \mathrm{H}) ;{ }^{13} \mathrm{C} \mathrm{NMR}\left(\mathrm{CDCl}_{3} / 75 \mathrm{MHz}\right) \delta 172.6,171.1,170.3$, $154.8,138.0,137.4,137.0,135.9,134.2,133.9,133.7,130.0,129.5,129.4,128.7,128.5,128.4,128.0$, $127.0,126.9,79.4,60.4,59.1,54.8,53.8,53.1,52.3,50.3,50.2,41.0,31.4,28.7,28.5,28.5,27.2$, 25.8, 1.9, -3.2, -3.8, -3.9; IR (neat/NaCl) 3434, 1742, 1713, 1645, 1634, 1495, 1428, $1170 \mathrm{~cm}^{-1}$; LRFAB MS (relative intensity) $\mathrm{m} / \mathrm{z} 517$ (74) $\mathrm{MLi}^{+}, 495$ (8) $\mathrm{M}^{+}-\mathrm{CH}_{3}, 466$ (4), 433 (14) $\mathrm{MLi}^{+}-\mathrm{C}_{4} \mathrm{H}_{8}-\mathrm{CO}, 417$ (25) $\mathrm{MLi}^{+}-\mathrm{Boc}+\mathrm{H}, 377$ (94), 313 (100); HRFAB MS m/z calculated for [M+Li] 517.2710, found 517.2700.

\section{1-(2-tert-Butoxycarbonylamino-3-hydroxypropionyl)-5-(dimethylphenylsilyl)-pyrrolidine-2- carboxylic acid methyl ester (21):}

Prior to the coupling reaction, the Cbz protected silylated prolinol substrate (1.05 g, $2.6 \mathrm{mmol})$ synthesized in the previous experimental was deprotected using the general procedure described earlier. A $250 \mathrm{~mL}$ round bottom flask was charged with $\mathrm{N}$-(tert-butoxycarbonyl)-serine (616 $\mathrm{mg}, 3.0 \mathrm{mmol}), \mathrm{N}$ methylmorpholine $(0.99 \mathrm{~mL}, 9.0 \mathrm{mmol})$, isobutylchloroformate $(0.428 \mathrm{~mL}, 3.3 \mathrm{mmol})$ and $\mathrm{CH}_{2} \mathrm{Cl}_{2}(60$ $\mathrm{mL})$. The reaction mixture was stirred at $-15{ }^{\circ} \mathrm{C}$ for $25 \mathrm{~min}$. A solution of the crude silylated proline amine substrate in $\mathrm{CH}_{2} \mathrm{Cl}_{2}(6 \mathrm{~mL})$ was canulated into the reaction. An additional $2 \mathrm{~mL}$ of dichloromethane was used in order to ensure complete transfer of the substrate. The mixture was then warmed to room temperature and stirred for $12 \mathrm{~h}$. The reaction was quenched with water and the layers were separated. Then the organic layer was washed with water and then dried over the $\mathrm{MgSO}_{4}$. After filtration, the filtrate was concentrated under reduced pressure. The residue was chromatographed through a silica gel column using an eluant of 1:1 hexane/EtOAc to afford $690 \mathrm{mg} \mathrm{(58 \% )}$ of the silated dipeptide product. Two isomers of the product were obtained in a 2:1 ratio. Isomer 1: ${ }^{1} \mathrm{H}$ NMR $\left(\mathrm{CDCl}_{3} / 300 \mathrm{MHz}\right)$ (two main rotamers with approximately 9:1 ratio) $\delta 7.54-7.51(\mathrm{~m}, 2 \mathrm{H}), 7.39-7.32(\mathrm{~m}$, $3 \mathrm{H}), 5.65(\mathrm{~d}, \mathrm{~J}=8.4 \mathrm{~Hz}, 0.9 \mathrm{H}), 5.54(\mathrm{~d}, \mathrm{~J}=6.9 \mathrm{~Hz}, 0.1 \mathrm{H}), 5.13(\mathrm{dd}, \mathrm{J}=7.5,2.3 \mathrm{~Hz}, 1 \mathrm{H}), 4.43-4.35(\mathrm{~m}, 0.1 \mathrm{H})$, 4.25-4.21 (m, 0.9H), 3.67 (s, 3H), 3.77-3.57 (m, 2H), 3.44-3.41 (broad d, 1H), 2.15-2.00 (m, 2H), 1.87$1.71(\mathrm{~m}, 2 \mathrm{H}), 1.43$ and 1.41 ( $\mathrm{s}$ and $\mathrm{s}, 9 \mathrm{H}), 0.47,0.44,0.42,0.41(\mathrm{~s}, \mathrm{~s}, \mathrm{~s}$ and $\mathrm{s}, 6 \mathrm{H}),{ }^{13} \mathrm{C} \mathrm{NMR}\left(\mathrm{CDCl}_{3} / 75\right.$ $\mathrm{MHz}) \delta 172.4,171.9,155.9,138.0,134.3,129.2,128.2,127.7,80.1,63.7,60.5,52.7,51.6,50.2,31.1$, 28.4, 27.2, -2.5, -4.1; IR (neat/NaCl) 3427, 1744, 1714, 1633, 1503, 1447, $1171 \mathrm{~cm}^{-1}$; LRFAB MS (relative intensity) $\mathrm{m} / \mathrm{z} 451$ (10) $\mathrm{MLi}^{+}, 435$ (2), 373 (4) $\mathrm{MLi}^{+}-\mathrm{PhH}, 334$ (2) $\mathrm{MLi}^{+}-\mathrm{Boc}_{-} \mathrm{NH}_{2}, 317$ (26), 
299(18), 154 (100), 136 (88), 107 (42), 89 (66), ; HRFAB MS m/z calculated for $[\mathrm{M}+\mathrm{H}]^{+}$451.2200, found 451.2214. Isomer 2: ${ }^{1} \mathrm{H}$ NMR $\left(\mathrm{CDCl}_{3} / 300 \mathrm{MHz}\right)$ (two main rotamers with approximately 2:1 ratio observed) $\delta 7.76-7.73(\mathrm{~m}, 0.33 \mathrm{H}), 7.60-7.51(\mathrm{~m}, 1.33 \mathrm{H}), 7.42-7.33(\mathrm{~m}, 3.33 \mathrm{H}), 5.37(\mathrm{~d}, 9.9 \mathrm{~Hz}, 0.33 \mathrm{H})$, $5.23(\mathrm{~d}, 8.7 \mathrm{~Hz}, 0.67 \mathrm{H}), 4.66-4.63(\mathrm{~m}, 0.33 \mathrm{H}), 4.46-4.38(\mathrm{~m}, 0.67 \mathrm{H}), 4.01-3.98(\mathrm{~m}, 0.33 \mathrm{H}), 3.87-3.80(\mathrm{~m}$, $0.67 \mathrm{H}), 3.79$ and $3.72(\mathrm{~s}$ and $\mathrm{s}, 3 \mathrm{H}), 3.70-3.52(\mathrm{~m}, 2 \mathrm{H}), 3.19-3.09(\mathrm{~m}, 1 \mathrm{H}), 2.33-1.98(\mathrm{~m}, 2 \mathrm{H}), 1.89-1.66$ $(\mathrm{m}, 2 \mathrm{H}), 1.46,1.45$ and $1.42(\mathrm{~s}, \mathrm{~s}$ and $\mathrm{s}, 9 \mathrm{H}), 0.48,0.46,0.45$ and $0.40(\mathrm{~s}, \mathrm{~s}, \mathrm{~s}$ and $\mathrm{s}, 6 \mathrm{H}) ;{ }^{13} \mathrm{C} \mathrm{NMR}$ $\left(\mathrm{CDCl}_{3} / 75 \mathrm{MHz}\right) \delta 172.6,172.3,169.8,155.6,138.7,135.0,134.3,134.1,130.0,129.1,128.3,128.0$, $127.7,80.4,64.2,62.9,60.4,59.9,53.7,52.7,52.4,50.6,50.3,32.1,28.9,28.5,28.4,28.0,26.9,-2.2$, 3.4, -4.2; IR (neat/NaCl) 3427, 1744, 1714, 1633, 1503, 1447, $1171 \mathrm{~cm}^{-1}$; LRFAB MS (relative intensity) $\mathrm{m} / \mathrm{z} 451$ (10) $\mathrm{MLi}^{+}, 435$ (2), 373 (4) $\mathrm{MLi}^{+}-\mathrm{PhH}, 334$ (2) $\mathrm{MLi}^{+}-\mathrm{Boc}-\mathrm{NH}_{2}, 317$ (26), 299(18), 154 (100), 136 (88), 107 (42), 89 (66), ; HRFAB MS m/z calculated for $[\mathrm{M}+\mathrm{H}]^{+} 451.2200$, found 451.2214.

\section{5-(Dimethylphenylsilyl)-1-[2-(1,3-dioxo-1,3-dihydroisoindol-2-yl)-pent-4-enoyl]-pyrrolidine-2- carboxylic acid methyl ester (22):}

Prior to the coupling reaction, the Cbz protected silylated proline substrate $(1.5 \mathrm{~g}, 3.78 \mathrm{mmol})$ was deprotected using the general procedure described above. Phthalimide protected-homoallylglycine was prepared by treating 2-aminopent-4-enoic acid $(240 \mathrm{mg}, 2.08 \mathrm{mmol})$ with 1,3-dioxo-1,3-dihydroisoindole-2-carboxylic acid ethyl ester $(470 \mathrm{mg}, 2.29 \mathrm{mmol})$ and sodium carbonate $(242 \mathrm{mg}, 2.29 \mathrm{mmol})$ in $3 \mathrm{~mL}$ of water. The mixture was stirred at room temperature for 1 hour and then neutralized with $1 \mathrm{M}$ $\mathrm{NaHSO}_{4}$ solution to $\mathrm{pH}=2$. The layers are separated and aqueous layer washed three times with EtOAc. The combined organic layers were concentrated in vacuo and the crude product used directly for the next step without purification.

A $100 \mathrm{~mL}$ round bottom flask was charged with Phth-homoallylglycine (crude, $400 \mathrm{mg}, \sim 1.64$ mmol) and ether $(2.76 \mathrm{~mL}) . \mathrm{PCl}_{5}(0.99 \mathrm{~mL}, 9.0 \mathrm{mmol})$ was added and the mixture stirred at room temperature for 1 hour until all the $\mathrm{PCl}_{5}$ was dissolved. The solution was decanted and washed with ether. The combined ether solution was concentrated under reduced pressure leading to the crude product of the acid chloride as a yellow solid.

A $250 \mathrm{~mL}$ round bottom flask was charged with the deprotected proline derivative (crude, $\leq 3.78$ $\mathrm{mmol})$, triethylamine $(0.71 \mathrm{~mL}, 4.6 \mathrm{mmol})$, and ether $(10.5 \mathrm{~mL})$. The crude phthalimide protectedhomoallylglycine acid chloride in ether $(5 \mathrm{~mL})$ was then canulated into the above solution. Ether $(2 \mathrm{~mL})$ was used to ensure a complete transfer of the substrate. The reaction mixture was stirred at room temperature for $12 \mathrm{~h}$ and quenched with water. The layers were separated and the organic layer was washed with water before being dried over the $\mathrm{MgSO}_{4}$. After filtration, the filtrate was concentrated under reduced pressure. The residue was chromatographed through a silica gel column using an eluant of 1:3.5 hexane/EtOAc to afford $381 \mathrm{mg}(47 \%)$ of the silated dipeptide product. ${ }^{1} \mathrm{H}$ NMR $\left(\mathrm{CDCl}_{3} / 300 \mathrm{MHz}\right) \delta$ 7.83-7.79 (m, 2H), 7.74-7.68 (m, 2H), 7.58-7.49 (m, 2H), 7.35-7.33 (m, 3H), 5.76-5.65 (m, 1H), 5.12 (d, $\mathrm{J}=20.1 \mathrm{~Hz}, 1 \mathrm{H}), 5.01(\mathrm{~d}, \mathrm{~J}=10.2 \mathrm{~Hz}, 1 \mathrm{H}), 4.93-4.85(\mathrm{~m}, 2 \mathrm{H}), 3.74(\mathrm{~s}, 3 \mathrm{H}), 3.68(\mathrm{t}, \mathrm{J}=8.7 \mathrm{~Hz}, 1 \mathrm{H}), 3.56-3.45$ $(\mathrm{m}, 1 \mathrm{H}), 2.63-2.54(\mathrm{~m}, 1 \mathrm{H}), 2.09-2.01(\mathrm{~m}, 2 \mathrm{H}), 1.79-1.68(\mathrm{~m}, 2 \mathrm{H}), 0.48(\mathrm{~s}, 3 \mathrm{H}), 0.44(\mathrm{~s}, 3 \mathrm{H}) ;{ }^{13} \mathrm{C}$ NMR $\left(\mathrm{CDCl}_{3} / 75 \mathrm{MHz}\right) \delta 172.6,168.4,168.3,138.2,134.4,134.3,134.1,131.9,129.2,127.8,123.6,118.5$, $60.3,53.7,52.7,50.6,32.8,31.8,27.0,-2.2,-4.5$; IR (neat/NaCl) 1745, 1714, 1650, 1382, $718 \mathrm{~cm}^{-1}$; LRFAB MS (relative intensity) m/z 491 (4) $\mathrm{MLi}^{+}, 431$ (2) $\mathrm{MLi}^{+}-\mathrm{COO}=\mathrm{CH}_{2}, 413$ (27) $\mathrm{MLi}^{+}-\mathrm{PhH}, 289$ (11), 252 (8), 200 (24), 136 (100), 89 (84); HRFAB MS m/z calculated for $[\mathrm{M}+\mathrm{H}]^{+}$491.1935, found 491.1940 .

\section{1-(2-tert-Butoxycarbonylamino-3-phenylpropionyl)-5-methoxy-pyrrolidine-2-carboxylic acid} methyl ester:

The silylated dipeptide substrate $(385 \mathrm{mg}, 0.76 \mathrm{mmol}$ ) was oxidized using the general procedure outlined above. In this experiment, $2.1 \mathrm{~F} / \mathrm{mol}$ of current was passed through the cell. The crude product was chromatographed through silica gel using a gradient elution from 1:3 EtOAc/hexane to 1:2 EtOAc/hexane. The column afforded $250 \mathrm{mg}(82 \%)$ of the desired product along with $17 \mathrm{mg}(4.4 \%)$ of 
recovered starting material. Two isomers of the product were obtained in a 2:1 ratio. Isomer 1: ${ }^{1} \mathrm{H}$ NMR $\left(\mathrm{CDCl}_{3} / 300 \mathrm{MHz}\right)$ (two main rotamers with approximately 9:1 ratio observed) $\delta 7.33-7.24(\mathrm{~m}, 5 \mathrm{H}), 5.46$ $(\mathrm{d}, \mathrm{J}=3.9 \mathrm{~Hz}, 0.1 \mathrm{H}), 5.33(\mathrm{~d}, \mathrm{~J}=8.7 \mathrm{~Hz}, 0.9 \mathrm{H}), 4.77-4.70(\mathrm{~m}, 1 \mathrm{H}), 4.53(\mathrm{~d}, \mathrm{~J}=9.3 \mathrm{~Hz}, 1 \mathrm{H}), 4.43(\mathrm{~d}, \mathrm{~J}=3.9 \mathrm{~Hz}$, $1 \mathrm{H}), 3.75$ and 3.72 (s and s, 3H), 3.39 and 3.23 (s and s, 3H), 3.10-2.94 (m, 2H), 2.32-2.20 (m 1H), 1.92$1.86(\mathrm{~m}, 2 \mathrm{H}), 1.79-1.60(\mathrm{~m}, 1 \mathrm{H}), 1.39(\mathrm{~s}, 9 \mathrm{H}) ;{ }^{13} \mathrm{C} \mathrm{NMR}\left(\mathrm{CDCl}_{3} / 75 \mathrm{MHz}\right) \delta 172.1,172.0,154.9,136.9$, $129.9,129.7,128.6,127.0,88.8,79.6,58.7,55.1,53.9,52.4,40.8,29.7,29.5,28.5,25.9$; IR (neat/NaCl) 3314, 1742, 1651, 1520, 1249, 1169, $853 \mathrm{~cm}^{-1}$; LRFAB MS (relative intensity) m/z 413 (100) $\mathrm{MLi}^{+}, 397$ (6), 395 (57) $\mathrm{MLi}^{+}-\mathrm{H}_{2} \mathrm{O}, 313$ (61) $\mathrm{MLi}^{+}-\mathrm{Boc}+\mathrm{H}, 289$ (20); HRFAB MS m/z calculated for [M+Li] ${ }^{+}$ 413.2264, found 413.2246. Isomer 2: ${ }^{1} \mathrm{H}$ NMR $\left(\mathrm{CDCl}_{3} / 300 \mathrm{MHz}\right)$ (two main rotamers with approximately $2: 1$ ratio observed) $\delta 7.32-7.20(\mathrm{~m}, 5 \mathrm{H}), 5.48(\mathrm{~d}, \mathrm{~J}=4.8 \mathrm{~Hz}, 0.67 \mathrm{H}), 5.39(\mathrm{~d}, \mathrm{~J}=5.1 \mathrm{~Hz}$, $0.33 \mathrm{H}), 5.01(\mathrm{~d}, \mathrm{~J}=9.3 \mathrm{~Hz}, 1 \mathrm{H}), 4.73(\mathrm{td}, \mathrm{J}=9.0,3.9 \mathrm{~Hz}, 1 \mathrm{H}), 4.46-4.40(\mathrm{~m}, 1 \mathrm{H}), 3.75$ and $3.71(\mathrm{~s}$ and s, $3 \mathrm{H})$, 3.36 and $3.33(\mathrm{~s}$ and $\mathrm{s}, 3 \mathrm{H}), 3.49-3.26(\mathrm{~m}, 1 \mathrm{H}), 2.86-2.79(\mathrm{~m}, 1 \mathrm{H}), 2.32-1.90(\mathrm{~m}, 4 \mathrm{H}), 1.45,1.42$ and 1.34 (s, s and s, 9H); ${ }^{13} \mathrm{C}$ NMR $\left(\mathrm{CDCl}_{3} / 75 \mathrm{MHz}\right) \delta 172.9,172.1,172.0,137.1,129.6,128.8,128.5,128.4$, 127.3, 89.2, 87.7, 79.9, 59.4, 58.2, 56.2, 54.1, 53.6, 53.3, 52.9, 52.4, 41.4, 39.0, 31.1, 30.6, 28.5, 28.4, 27.2, 26.5, 26.1; IR (neat/NaCl) 3314, 1742, 1651, 1520, 1249, 1169, $853 \mathrm{~cm}^{-1}$; LRFAB MS (relative intensity) $\mathrm{m} / \mathrm{z} 413$ (100) $\mathrm{MLi}^{+}, 397$ (6), 395 (57) $\mathrm{MLi}^{+}-\mathrm{H}_{2} \mathrm{O}, 313$ (61) $\mathrm{MLi}^{+}-\mathrm{Boc}+\mathrm{H}, 289$ (20); HRFAB $\mathrm{MS} \mathrm{m} / \mathrm{z}$ calculated for $[\mathrm{M}+\mathrm{Li}]^{+} 413.2264$, found 413.2246 .

\section{2-Benzyl-3-oxo-hexahydropyrrolo[1,2-a]imidazole-5-carboxylic acid methyl ester (23):}

To an oven-dried $50 \mathrm{~mL}$ round bottom flask was added the methoxylated dipeptide substrate (175 $\mathrm{mg}, 0.43 \mathrm{mmol})$ and anhydrous ether $(15 \mathrm{~mL})$ at $-78{ }^{\circ} \mathrm{C} . \mathrm{BF}_{3} \mathrm{Et}_{2} \mathrm{O}(54.5 \mu \mathrm{l}, 0.43 \mathrm{mmol})$ was added and the reaction mixture was allowed to stir at $-78{ }^{\circ} \mathrm{C}$ for 1 hour. The solution was then allowed to warm to room temperature over a period of $30 \mathrm{~min}$. The reaction was quenched with sat. sodium bicarbonate solution and transferred to a separatory funnel. The layers were separated and the aqueous layer extracted with ether. The combined organic layers were dried over $\mathrm{MgSO}_{4}$ and concentrated in vacuo. The crude product was chromatographed through silica gel using a gradient elution from 1:1 EtOAc/hexane to 5\% methanol/EtOAc. The column afforded $88 \mathrm{mg}(75 \%)$ of the desired cyclized product. ${ }^{1} \mathrm{H}$ NMR $\left(\mathrm{CDCl}_{3} / 300 \mathrm{MHz}\right) \delta$ 7.30-7.16 (m, 5H), $4.94(\mathrm{dd}, \mathrm{J}=7.4,5.0 \mathrm{~Hz}, 1 \mathrm{H}), 4.42(\mathrm{dd}, \mathrm{J}=9.2,6.2 \mathrm{~Hz}, 1 \mathrm{H}), 4.16$ $(\mathrm{dd}, \mathrm{J}=8.3,3.8 \mathrm{~Hz}, 1 \mathrm{H}), 3.72(\mathrm{~s}, 3 \mathrm{H}), 3.14(\mathrm{dd}, \mathrm{J}=13.8,3.6 \mathrm{~Hz}, 1 \mathrm{H}), 2.76(\mathrm{dd}, \mathrm{J}=13.8,8.7 \mathrm{~Hz}, 1 \mathrm{H}), 2.34-$ $2.23(\mathrm{~m}, 2 \mathrm{H}), 2.03-1.90(\mathrm{~m}, 2 \mathrm{H}), 1.14-1.05(\mathrm{~m}, 1 \mathrm{H}) ;{ }^{13} \mathrm{C} \mathrm{NMR}\left(\mathrm{CDCl}_{3} / 75 \mathrm{MHz}\right) \delta 174.9,172.2,138.3$, 129.7, 128.5, 126.6, 76.0, 63.9, 55.1, 52.6, 39.0, 33.3, 29.8; IR (neat/NaCl) 3353, 2951, 1744, 1707, 1401, 1200, $1178 \mathrm{~cm}^{-1}$; LRFAB MS (relative intensity) m/z 275 (14) $\mathrm{MH}^{+}, 154$ (100); HRFAB MS m/z calculated for $[\mathrm{M}+\mathrm{H}]^{+}$275.1396, found 275.1392. The stereochemistry was assigned using an NOE crosspeak between the proton on the bridge-head carbon and the proton on the carbon next to the benzyl.

1-(2-tert-Butoxycarbonylamino-3-hydroxypropionyl)-5-methoxypyrrolidine-2-carboxylic acid methyl ester:

The silylated dipeptide substrate $(202 \mathrm{mg}, 0.45 \mathrm{mmol}$ ) was oxidized using the general procedure outlined above. In this experiment, $2.2 \mathrm{~F} / \mathrm{mol}$ of current was passed through the electrolysis cell. The crude product was chromatographed through silica gel using a gradient elution from 1:1.5 EtOAc/hexane to $10 \%$ mehthanol/EtOAc. The column afforded $118 \mathrm{mg}(76 \%)$ of the desired product as a mixture of two isomers (1:1 ratio). Isomer 1: ${ }^{1} \mathrm{H} \mathrm{NMR}\left(\mathrm{CDCl}_{3} / 300 \mathrm{MHz}\right) \delta 5.51$ (br s, $\left.1 \mathrm{H}\right), 5.26(\mathrm{dd}, \mathrm{J}=5.0,4.0 \mathrm{~Hz}$, $1 \mathrm{H}), 4.76(\mathrm{dd}, \mathrm{J}=7.4,5.2 \mathrm{~Hz}, 1 \mathrm{H}), 4.48-4.37(\mathrm{~m}, 2 \mathrm{H}), 3.75(\mathrm{~s}, 3 \mathrm{H}), 3.69(\mathrm{dd}, \mathrm{J}=10.0,6.4 \mathrm{~Hz}, 1 \mathrm{H}), 3.48(\mathrm{~s}$, $3 \mathrm{H}), 2.35-2.29(\mathrm{~m}, 2 \mathrm{H}), 2.02-1.95(\mathrm{~m}, 2 \mathrm{H}), 1.45(\mathrm{~s}, 9 \mathrm{H}) ;{ }^{13} \mathrm{C} \mathrm{NMR}\left(\mathrm{CDCl}_{3} / 75 \mathrm{MHz}\right) \delta 171.9,171.6$, 171.3, 166.8, 155.9, 89.1, 88.0, 87.5, 80.3, 69.3, 68.8, 64.0, 59.2, 59.0, 58.8, 58.2, 57.9, 54.7, 52.9, 52.7, 52.5, 49.2 , 31.9, 31.6, 31.2, 30.9, 30.2, 28.9, 28.4, 27.8, 26.5, 26.3, 26.2, 26.0; IR (neat/NaCl) 3432, 2978, 1747, 1714, 1667, 1435, 1170, 1086, $859 \mathrm{~cm}^{-1}$; LRFAB MS (relative intensity) m/z 353 (100) $\mathrm{MLi}^{+}, 253$ (20) $\mathrm{MLi}^{+}-\mathrm{Boc}+\mathrm{H}, 134$ (53); HRFAB MS m/z calculated for $[\mathrm{M}+\mathrm{Li}]^{+} 353.1919$, found 353.1923. Isomer 2: ${ }^{1} \mathrm{H}$ NMR $\left(\mathrm{CDCl}_{3} / 300 \mathrm{MHz}\right) \delta 5.49(\mathrm{~d}, \mathrm{~J}=4.2 \mathrm{~Hz}, 1 \mathrm{H}), 5.38(\mathrm{~d}, \mathrm{~J}=7.5 \mathrm{~Hz}, 1 \mathrm{H}), 4.83(\mathrm{br} \mathrm{d}, \mathrm{J}=6.6 \mathrm{~Hz}, 1 \mathrm{H})$, 4.69 (d, J=9.3Hz, 1H), 3.89 (dd, J=11.1, 5.4Hz, 1H), 3.76 (s, 3H), 3.63 (dd, J=11.1, 8.1Hz, 1H), 3.38 (s, 
$3 \mathrm{H}), 2.49-2.35(\mathrm{~m}, 1 \mathrm{H}), 2.12-1.88(\mathrm{~m}, 3 \mathrm{H}), 1.44$ and $1.43(\mathrm{~s}$ and $\mathrm{s}, 9 \mathrm{H}) ;{ }^{13} \mathrm{C} \mathrm{NMR}\left(\mathrm{CDCl}_{3} / 75 \mathrm{MHz}\right) \delta$ $171.9,171.6,171.3,166.8,155.9,89.1,88.0,87.5,80.3,69.3,68.8,64.0,59.2,59.0,58.8,58.2$, 57.9, $54.7,52.9,52.7,52.5,49.2,31.9,31.6,31.2,30.9,30.2,28.9,28.4,27.8,26.5,26.3,26.2,26.0$; IR (neat/ $\mathrm{NaCl}$ ) 3432, 2978, 1747, 1714, 1667, 1435, 1170, 1086, $859 \mathrm{~cm}^{-1}$; LRFAB MS (relative intensity) $\mathrm{m} / \mathrm{z} 353$ (100) $\mathrm{MLi}^{+}, 253$ (20) $\mathrm{MLi}^{+}-\mathrm{Boc}+\mathrm{H}, 134$ (53); HRFAB MS m/z calculated for [M+Li] 353.1919 , found 353.1923 .

\section{3-tert-Butoxycarbonylamino-4-oxo-hexahydropyrrolo[2,1-b][1,3]oxazine-6-carboxylic acid methyl ester (24):}

To an oven-dried $50 \mathrm{~mL}$ round bottom flask was added the methoxylated dipeptide substrate (83 $\mathrm{mg}, 0.24 \mathrm{mmol})$ synthesized above and anhydrous dichloromethane $(10 \mathrm{~mL})$. The solution was cooled to $-20{ }^{\circ} \mathrm{C}$ and trifluoroacetic acid $(5.0 \mu \mathrm{l}, 0.065 \mathrm{mmol})$ added. The mixture was then stirred at $-20{ }^{\circ} \mathrm{C}$ for 1 hour before being allowed to warm to room temperature over a period of $30 \mathrm{~min}$. The reaction was quenched with triethylamine $(15 \mu \mathrm{L})$ and concentrated directly under reduced pressure. The crude product was chromatographed through silica gel using a gradient elution from 1:1 EtOAc/hexane to 2:1 EtOAc/hexane. The column afforded $61 \mathrm{mg}(81 \%)$ of the desired cyclized product. ${ }^{1} \mathrm{H} \mathrm{NMR}\left(\mathrm{CDCl}_{3} / 300\right.$ MHz) $\delta 5.48($ br s, $1 \mathrm{H}), 5.26(\mathrm{dd}, \mathrm{J}=5.4,4.0 \mathrm{~Hz}, 1 \mathrm{H}), 4.76(\mathrm{dd}, \mathrm{J}=7.5,5.1 \mathrm{~Hz}, 1 \mathrm{H}), 4.50-4.46$ (broad, $1 \mathrm{H})$, $4.41(\mathrm{t}, \mathrm{J}=9.0 \mathrm{~Hz}, 1 \mathrm{H}), 3.75(\mathrm{~s}, 3 \mathrm{H}), 3.68(\mathrm{dd}, \mathrm{J}=10.2,6.5 \mathrm{~Hz}, 1 \mathrm{H}), 2.38-2.27(\mathrm{~m}, 2 \mathrm{H}), 2.05-1.93(\mathrm{~m}, 2 \mathrm{H})$, 1.45 (s, 9H); ${ }^{13} \mathrm{C}$ NMR $\left(\mathrm{CDCl}_{3} / 75 \mathrm{MHz}\right) \delta 171.6,166.8,155.9,87.6,80.4,68.9,58.2,52.8,49.3,31.7$, 28.5, 26.3; IR (neat/NaCl) 3351, 1745, 1682, 1436, $1167 \mathrm{~cm}^{-1}$; LRFAB MS (relative intensity) $\mathrm{m} / \mathrm{z} 315$ (9) $\mathrm{MH}^{+}, 289$ (4), 259 (50) $\mathrm{MH}^{+}-\mathrm{C}_{4} \mathrm{H}_{8}, 215$ (16) $\mathrm{MH}^{+}-\mathrm{Boc}+\mathrm{H}, 154$ (51), 128 (100), 107 (47); HRFAB MS m/z calculated for $[\mathrm{M}+\mathrm{H}]^{+} 315.1558$, found 315.1559 . The stereochemistry was assigned using the NOE crosspeak between the proton on the bridgehead carbon and the proton on the carbon next to the BocNH- group and the NOE crosspeak between the proton on the bridgehead carbon and the proton on the carbon next to the -COOMe group.

\section{1-[2-(1,3-Dioxo-1,3-dihydroisoindol-2-yl)-pent-4-enoyl]-5-methoxypyrrolidine-2-carboxylic acid methyl ester:}

The silylated dipeptide substrate $(280 \mathrm{mg}, 0.57 \mathrm{mmol})$ was oxidized using the general procedure

outlined above. In this experiment, $2.1 \mathrm{~F} / \mathrm{mol}$ of current was passed through the cell. In addition, six equivalents of 2, 6-lutidine was added as a proton scavenger. The crude product from the electrolysis was chromatographed through silica gel using a gradient elution from 1:2 EtOAc/hexane to 1:1 EtOAc/hexane. The column afforded $162 \mathrm{mg}(73 \%)$ of the desired product as a $2: 1$ ratio of isomers. ${ }^{1} \mathrm{H}$ $\mathrm{NMR}\left(\mathrm{CDCl}_{3} / 300 \mathrm{MHz}\right)$ (mixture of two diastereomers with approximately 2:1 ratio and their rotamers) $\delta$ 7.87-7.82 (m, 2H), 7.74-7.71 (m, 2H), 5.83-5.7 (m, 1H), 5.30 (dd, J=22.9, 4.4Hz, 0.5H), 5.19-4.95 (m, $3.5 \mathrm{H}), 4.63(\mathrm{~d}, \mathrm{~J}=9.3 \mathrm{~Hz}, 0.33 \mathrm{H}), 4.52(\mathrm{~d}, \mathrm{~J}=9.0 \mathrm{~Hz}, 0.33 \mathrm{H}), 4.39(\mathrm{t}, \mathrm{J}=8.4 \mathrm{~Hz}, 0.34 \mathrm{H}), 3.75,3.74$ and 3.64 (s, s and s, 3H), 3.46, 3.40 and $2.77\left(\mathrm{~s}, \mathrm{~s}\right.$ and s, 3H), 3.08-2.83 (m, 2H), 2.33-1.81 (m, 4H); ${ }^{13} \mathrm{C}$ NMR $\left(\mathrm{CDCl}_{3} / 75 \mathrm{MHz}\right) \delta 179.4,176.3,172.6,171.9,169.1,168.2,167.8,148.1,134.4,134.3,134.2,133.9$, 133.7, 132.1, 131.8, 131.8, 123.7, 123.6, 123.5, 119.4, 118.9, 118.7, 118.6, 89.0, 88.8, 88.3, 75.2, 59.7, 59.4, 54.5, 54.3, 53.6, 53.0, 52.5, 52.5, 52.3, 51.3, 37.5, 34.0, 33.1, 30.8, 29.2, 28.4, 26.3, 25.8, 25.5, 20.9; IR (neat/NaCl) 3478, 2953, 1748, 1715, 1673, 1384, 1201, 1086, 783, $721 \mathrm{~cm}^{-1}$; LRFAB MS (relative intensity) $\mathrm{m} / \mathrm{z} 387$ (1) $\mathrm{MLi}^{+}, 355$ (15) $\mathrm{MLi}^{+}-\mathrm{CH}_{3} \mathrm{OH}, 228$ (8), 200 (100), 136 (24), 89 (31); HRFAB MS $\mathrm{m} / \mathrm{z}$ calculated for $[\mathrm{M}+\mathrm{H}]^{+} 387.1557$, found 387.1558 .

\section{8-Chloro-6-(1,3-dioxo-1,3-dihydroisoindol-2-yl)-5-oxooctahydropyrrolo[1,2-a]azepine-3-carboxylic acid methyl ester (25):}

A $100 \mathrm{~mL}$ round-bottom flask was charged with the methoxylated dipeptide substrate $(97 \mathrm{mg}$, $0.25 \mathrm{mmol})$ generated above and dichloromethane $(25 \mathrm{~mL})$. The solution was cooled to $-78{ }^{\circ} \mathrm{C}$ and a titanium (IV) chloride $(0.50 \mathrm{~mL}, 1.0 \mathrm{M})$ in dichloromethane solution added slowly. After $30 \mathrm{~min}$, the reaction was warmed to room temperature and stirred for $40 \mathrm{~h}$. The reaction was quenched with a 
dropwise addition of a $30 \%(\mathrm{w} / \mathrm{w})$ sodium potassium tartrate solution $(3 \mathrm{~mL})$ and transferred to a $125 \mathrm{~mL}$ Erlenmeyer flask. An additional $5 \mathrm{~mL}$ sodium potassium tartrate solution added. The resulting emulsion was stirred for $3 \mathrm{~h}$ until two clear layers were formed. The mixture was transferred to a separatory funnel and the layers separated. The aqueous layer was extracted five times with dichloromethane and then the combined organic layers were dried over $\mathrm{MgSO}_{4}$ and concentrated in vacuo. The crude product was chromatographed through a silica gel column using an eluant of 1:1 EtOAc/hexane. The column afforded $33 \mathrm{mg}(64 \%)$ of the desired product. ${ }^{1} \mathrm{H}$ NMR $\left(\mathrm{CDCl}_{3} / 300 \mathrm{MHz}\right) \delta 7.84-7.83(\mathrm{~m}, 2 \mathrm{H}), 7.74-7.69(\mathrm{~m}, 2 \mathrm{H})$, $4.84(\mathrm{~d}, \mathrm{~J}=8.7 \mathrm{~Hz}, 1 \mathrm{H}), 4.70(\mathrm{t}, \mathrm{J}=5.4 \mathrm{~Hz}, 1 \mathrm{H}), 4.17(\mathrm{tt}, \mathrm{J}=12.0,3.6 \mathrm{~Hz}, 1 \mathrm{H}), 3.92(\operatorname{app~q}, \mathrm{J}=8.7 \mathrm{~Hz}, 1 \mathrm{H})$, $3.74(\mathrm{~s}, 3 \mathrm{H}), 3.16(\operatorname{app~q}, \mathrm{J}=12.9 \mathrm{~Hz}, 1 \mathrm{H}), 2.60(\mathrm{~d}, \mathrm{~J}=2.7 \mathrm{~Hz}, 1 \mathrm{H}), 2.56-2.22(\mathrm{~m}, 3 \mathrm{H}), 2.12-2.05(\mathrm{~m}, 2 \mathrm{H})$, 1.96-1.85 (m, $1 \mathrm{H}) ;{ }^{13} \mathrm{C} \mathrm{NMR}\left(\mathrm{CDCl}_{3} / 75 \mathrm{MHz}\right) \delta 172.3,168.1,167.3,134.3,123.8,60.8,57.9,56.6,52.8$, 51.9, 44.7, 38.8, 33.1, 27.8, 20.3; IR (neat/NaCl) 2926, 1717, 1662, 1390, 1356, $721 \mathrm{~cm}^{-1}$; LRFAB MS (relative intensity) $\mathrm{m} / \mathrm{z} 391$ (1) $\mathrm{MH}^{+}, 289$ (11) $\mathrm{M}^{+}-\mathrm{PhCO}-\mathrm{H}, 252$ (10), 154 (100), 136 (89), 89 (78); $\mathrm{HRFAB} \mathrm{MS} \mathrm{m} / \mathrm{z}$ calculated for $[\mathrm{M}+\mathrm{H}]^{+} 391.1062$, found 391.1056. The stereochemistry was assigned using an NOE crosspeak between the proton on the bridgehead carbon and the proton on the carbon next to the phthalimide protected amine.

\section{3-Phenyl-2-(trimethylsilylmethylamino)propionic acid methyl ester (27):}

A $250 \mathrm{~mL}$ oven-dried round bottom flask was charged with the hydrochloride salt of Lphenylalanine methyl ester $(3.2 \mathrm{~g}, 15 \mathrm{mmol})$, (chloromethyl)trimethylsilane $(3.14 \mathrm{~mL}, 22 \mathrm{mmol})$, KI $(3.7 \mathrm{~g}, 22 \mathrm{mmol}), \mathrm{K}_{2} \mathrm{CO}_{3}(3.1 \mathrm{~g}, 22 \mathrm{mmol})$ and DMF $(65 \mathrm{~mL})$. The suspension was stirred at $90{ }^{\circ} \mathrm{C}$ for 12 h. The mixture was then poured into water $(60 \mathrm{~mL})$ and extracted with ether $(4 \times 30 \mathrm{~mL})$. The extracts were combined and washed with water $(2 \times 30 \mathrm{~mL})$ and brine $(2 \times 30 \mathrm{~mL})$, and then dried over $\mathrm{MgSO}_{4}$ and concentrated in vacuo. The crude residue was chromatographed through a silica gel column (Hexane/EtOAc, 1:7) to give the silylated amino acid $2.8 \mathrm{~g} \mathrm{(69 \% )} \mathrm{as} \mathrm{colorless} \mathrm{oil.} \mathrm{The} \mathrm{spectroscopic} \mathrm{data}$ was consistent with that previously reported in the literature (Zhang, C.; Ito, H.; Maeda, Y.; Shiral, N.; Ikeda, S.; Sato, Y. J. Org. Chem. 1999, 64, 581.

\section{2-[(3-Benzyloxy-2-tert-butoxycarbonylaminopropionyl)trimethylsilylmethylamino]-3-phenyl- propionic acid methyl ester (51a - see below):}

A $250 \mathrm{~mL}$ round bottom flask was charged with tert-butoxycarbonyl-(O-benzyl)-serine $(1.02 \mathrm{~g}$, $3.45 \mathrm{mmol})$, N-methylmorpholine $(0.48 \mathrm{~mL}, 4.4 \mathrm{mmol})$, isobutylchloroformate $(0.45 \mathrm{~mL}, 3.5 \mathrm{mmol})$, and $\mathrm{CH}_{2} \mathrm{Cl}_{2}(65 \mathrm{~mL})$. The reaction mixture was stirred at $-15{ }^{\circ} \mathrm{C}$ for $25 \mathrm{~min}$. The silylated phenyl alanine was dissolved in $\mathrm{CH}_{2} \mathrm{Cl}_{2}(10 \mathrm{~mL})$ and cannulated into the reaction mixture above. An additional $2 \mathrm{~mL}$ of $\mathrm{CH}_{2} \mathrm{Cl}_{2}$ was used to ensure complete transfer. The mixture was then warmed to room temperature and stirred for $12 \mathrm{~h}$. The reaction was quenched with water and the layers were separated. Then the organic layer was washed with water and dried over the $\mathrm{MgSO}_{4}$. After filtration, the filtrate was concentrated in vacuo and the crude product chromatographed through a silica gel column using an eluant of 1:6 hexane/EtOAc to afford $863 \mathrm{mg}(51 \%)$ of the desired product. ${ }^{1} \mathrm{H}$ NMR $\left(\mathrm{CDCl}_{3} / 300 \mathrm{MHz}\right)$ (two main rotamers with approximately $1: 1$ ratio were observed $) \delta 7.32-7.12(\mathrm{~m}, 10 \mathrm{H}), 5.36(\mathrm{~d}, \mathrm{~J}=8.1 \mathrm{~Hz}, 0.5 \mathrm{H}), 5.15$ $(\mathrm{d}, \mathrm{J}=9.3 \mathrm{~Hz}, 0.5 \mathrm{H}), 5.08(\mathrm{t}, \mathrm{J}=7.4 \mathrm{~Hz}, 1 \mathrm{H}), 4.75-4.71(\mathrm{~m}, 1 \mathrm{H}), 4.58($ br s, $1 \mathrm{H}), 4.42(\mathrm{~d}, \mathrm{~J}=11.7 \mathrm{~Hz}, 0.5 \mathrm{H})$, $4.31(\mathrm{~d}, \mathrm{~J}=11.7 \mathrm{~Hz}, 0.5 \mathrm{H}), 3.73$ and $3.66(\mathrm{~s}$ and s, $3 \mathrm{H}), 3.60(\mathrm{~d}, \mathrm{~J}=6.0 \mathrm{~Hz}, 1 \mathrm{H}), 3.49-3.16(\mathrm{~m}, 2 \mathrm{H}), 3.08(\mathrm{~A}$ of $\left.\mathrm{AB}, \mathrm{J}_{\mathrm{AB}}=16.2 \mathrm{~Hz}, 0.5 \mathrm{H}\right), 3.08-3.03(\mathrm{~m}, 0.5 \mathrm{H}), 2.90(\mathrm{dd}, \mathrm{J}=13.6,7.6 \mathrm{~Hz}, 0.5 \mathrm{H}), 2.70$ (A of $\mathrm{AB}$, $\left.\mathrm{J}_{\mathrm{AB}}=14.1 \mathrm{~Hz}, 0.5 \mathrm{H}\right), 2.64\left(\mathrm{~B}\right.$ of $\left.\mathrm{AB}, \mathrm{J}_{\mathrm{AB}}=14.4 \mathrm{~Hz}, 0.5 \mathrm{H}\right), 1.91\left(\mathrm{~B}\right.$ of $\left.\mathrm{AB}, \mathrm{J}_{\mathrm{AB}}=16.5 \mathrm{~Hz}, 0.5 \mathrm{H}\right), 1.42$ and 1.40 (s and s, 9H), 0.07 and 0.06 (s and s, $9 \mathrm{H}) ;{ }^{13} \mathrm{C} \mathrm{NMR}\left(\mathrm{CDCl}_{3} / 75 \mathrm{MHz}\right) \delta 170.7,170.2,170.1,169.3,155.0$, 138.2 , 137.7, 137.5, 136.5, 129.3, 129.2, 128.6, 128.4, 128.3, 128.3, 127.9, 127.6, 127.5, 126.8, 79.6, $79.4,73.2,70.9,70.6,65.1,61.7,52.2,52.0,50.1,49.2,42.3,36.1,35.9,34.6,28.2,28.2,-0.8,-2.4$; IR (neat $/ \mathrm{NaCl}) 3431,2952,1744,1711,1637,1497,1455,1248,1170,854,736,700 \mathrm{~cm}^{-1}$; LRFAB MS (relative intensity) $\mathrm{m} / \mathrm{z} 549$ (41) $\mathrm{MLi}^{+}, 449$ (100) $\mathrm{MLi}^{+}-\mathrm{Boc}+\mathrm{H}, 91$ (12); HRFAB MS m/z calculated for $[\mathrm{M}+\mathrm{Li}]^{+}$549.2972, found 549.2982. 


\section{2-[(2-tert-Butoxycarbonylamino-3-hydroxypropionyl)trimethylsilylmethylamino]-3-phenyl-}

propionic acid methyl ester (28):

A $250 \mathrm{~mL}$ round bottom flask was charged with the benzyl protected serine substrate $(1.245 \mathrm{~g}$, $2.3 \mathrm{mmol})$, palladium hydroxide $(250 \mathrm{mg}, 20 \% \mathrm{w} / \mathrm{w})$, and methanol $(150 \mathrm{~mL})$. A hydrogen balloon was attached to the flask through a needle that was pushed through a rubber septum. The reaction was vigorously stirred at room temperature for $12 \mathrm{~h}$ and then filtered through a short column of celite. The filtrate was concentrated in vacuo to afford $680 \mathrm{mg}(66 \%)$ of a crude product that was carried on without further purification. ${ }^{1} \mathrm{H} \mathrm{NMR}\left(\mathrm{CDCl}_{3} / 300 \mathrm{MHz}\right)$ (two main rotamers with approximately 2:1 ratio were observed) $\delta 7.30-7.14(\mathrm{~m}, 5 \mathrm{H}), 5.58(\mathrm{~d}, \mathrm{~J}=7.8 \mathrm{~Hz}, 0.33 \mathrm{H}), 5.47(\mathrm{~d}, \mathrm{~J}=9.6 \mathrm{~Hz}, 0.67 \mathrm{H}), 5.24(\mathrm{dd}, \mathrm{J}=11.1$, $3.9 \mathrm{~Hz}, 0.67 \mathrm{H}), 4.48-4.45(\mathrm{br}, 0.33 \mathrm{H}), 3.91-3.80(\mathrm{~m}, 1 \mathrm{H}), 3.72$ and $3.71(\mathrm{~s}$ and $\mathrm{s}, 3 \mathrm{H}), 3.74-3.63(\mathrm{~m}, 1 \mathrm{H})$, $3.37-3.31(\mathrm{~m}, 1.66 \mathrm{H}), 3.28-2.88(\mathrm{~m}, 2 \mathrm{H}), 2.90\left(\mathrm{~A}\right.$ of $\left.\mathrm{AB}, \mathrm{J}_{\mathrm{AB}}=16.5 \mathrm{~Hz}, 0.33 \mathrm{H}\right), 2.74$ (A of $\mathrm{AB}$, $\left.\mathrm{J}_{\mathrm{AB}}=14.1 \mathrm{~Hz}, 0.67 \mathrm{H}\right), 2.38\left(\mathrm{~B}\right.$ of $\left.\mathrm{AB}, \mathrm{J}_{\mathrm{AB}}=14.1 \mathrm{~Hz}, 0.67 \mathrm{H}\right), 1.88\left(\mathrm{~B}\right.$ of $\left.\mathrm{AB}, \mathrm{J}_{\mathrm{AB}}=16.2 \mathrm{~Hz}, 0.33 \mathrm{H}\right), 0.40$ and $1.37(\mathrm{~s}$ and $\mathrm{s}, 9 \mathrm{H}), 0.02(\mathrm{~s}, 9 \mathrm{H}) ;{ }^{13} \mathrm{C} \mathrm{NMR}\left(\mathrm{CDCl}_{3} / 75 \mathrm{MHz}\right) \delta 172.5,170.2,170.0,169.2,155.7,155.2$, 137.6, 136.5, 129.1, 129.1, 128.8, 128.6, 127.1, 126.8, 80.0, 71.6, 71.0, 64.5, 64.4, 63.1, 62.3, 61.7, 52.6, 52.3, 52.1, 48.8, 42.0, 36.4, 35.5, 34.3, 31.6, 28.2, 28.1, 19.2, 13.8, -0.8, -1.1, -2.3; IR (neat/NaCl) 3434, $1745,1707,1628,1497,1248,1170 \mathrm{~cm}^{-1}$; LRFAB MS (relative intensity) $\mathrm{m} / \mathrm{z} 459$ (90) $\mathrm{MLi}^{+}, 359$ (100) $\mathrm{MLi}^{+}-\mathrm{Boc}+\mathrm{H}^{+}, 303$ (13), 160 (40); HRFAB MS m/z calculated for [M+Li] ${ }^{+}$459.2503, found 459.2495.

\section{2-(5-tert-Butoxycarbonylamino-4-oxo[1,3]oxazinan-3-yl)-3-phenylpropionic acid methyl ester (29):}

An oven-dried $50 \mathrm{~mL}$ three-neck round bottom flask was fitted with a Pt wire cathode, a RVC anode, and a septum. A syringe needle was pushed through the septum and used as a nitrogen inlet. The flask was charged with the silylated dipeptide substrate made above $(260 \mathrm{mg}, 0.58 \mathrm{mmol})$, anhydrous acetonitrile $(17.2 \mathrm{~mL})$, trifluroethanol $(1.9 \mathrm{~mL})$, and tetrabutylammonium tetrafluroborate $(189 \mathrm{mg}, 0.58$ mmol). The reaction mixture was degassed by sonication while a slow stream of nitrogen was passed through the solution for $10 \mathrm{~min}$. The mixture was then electrolyzed at a constant current of $21.0 \mathrm{~mA}$ until $1.9 \mathrm{~F} / \mathrm{mol}$ had been passed. When complete, the solvent was removed under reduced pressure and the crude oil chromatographed through silica gel using a gradient elution from 1:2.5 EtOAc/hexane to 1:1 EtOAc/hexane. The column afforded $98 \mathrm{mg}(45 \%)$ of the desired product along with $99 \mathrm{mg}(38 \%)$ of recovered starting material. ${ }^{1} \mathrm{H}$ NMR $\left(\mathrm{CDCl}_{3} / 300 \mathrm{MHz}\right) \delta$ 7.33-7.22 (m, 3H), 7.18-7.15 (m, 2H), 5.23 (br $\mathrm{s}, 1 \mathrm{H}), 4.87(\mathrm{dd}, \mathrm{J}=11.0,5.3 \mathrm{~Hz}, 1 \mathrm{H}), 4.70(\mathrm{~d}, \mathrm{~J}=7.8 \mathrm{~Hz}, 1 \mathrm{H}), 4.53(\mathrm{~d}, \mathrm{~J}=8.1 \mathrm{~Hz}, 1 \mathrm{H}), 4.34-4.29(\mathrm{~m}, 1 \mathrm{H})$, 4.11 (br s, 1H), $3.75(\mathrm{~s}, 3 \mathrm{H}), 3.47(\mathrm{t}, \mathrm{J}=10.1 \mathrm{~Hz}, 1 \mathrm{H}), 3.34(\mathrm{dd}, \mathrm{J}=14.4,5.4 \mathrm{~Hz}, 1 \mathrm{H}), 3.10$ (dd, J=14.6, $11.0 \mathrm{~Hz}, 1 \mathrm{H}), 1.42(\mathrm{~s}, 9 \mathrm{H}) ;{ }^{13} \mathrm{C} \mathrm{NMR}\left(\mathrm{CDCl}_{3} / 75 \mathrm{MHz}\right) \delta 170.2,167.4,155.7,136.3,128.8,127.2,80.1$, 68.3, 57.2, 52.6, 52.5, 49.9, 34.4, 28.2, 28.2; IR (neat/NaCl) 3360, 1744, 1715, 1667, 1497, 1249, 1166 $\mathrm{cm}^{-1}$; LRFAB MS (relative intensity) m/z 385 (19) $\mathrm{MLi}^{+}, 313$ (25), 160 (100); HRFAB MS m/z calculated for $[\mathrm{M}+\mathrm{Li}]^{+} 385.1951$, found 385.1943 .

2-[(2-tert-Butoxycarbonylaminoacetyl)trimethylsilanylmethylamino]-3-phenyl-propionic acid methyl ester (30a):

A $250 \mathrm{~mL}$ round bottom flask was charged with $\mathrm{N}$-(tert-butoxycarbonyl)glycine $(1.9 \mathrm{~g}, 11$ $\mathrm{mmol})$, NMM $(2.4 \mathrm{~mL}, 22 \mathrm{mmol})$, isobutylchloroformate $(1.51 \mathrm{~mL}, 12.1 \mathrm{mmol})$ and $\mathrm{CH}_{2} \mathrm{Cl}_{2}(180 \mathrm{~mL})$. The resulting solution was allowed to stir at $-15{ }^{\circ} \mathrm{C}$ for $25 \mathrm{~min}$. The $\mathrm{N}-\alpha$-silylated phenyl alanine methyl ester $(10 \mathrm{mmol})$ was dissolved in $\mathrm{CH}_{2} \mathrm{Cl}_{2}(10 \mathrm{~mL})$ and cannulated into the reaction mixture above. An additional $2 \mathrm{~mL}$ of $\mathrm{CH}_{2} \mathrm{Cl}_{2}$ was used to ensure the complete transfer. The mixture was then warmed to room temperature and stirred for $12 \mathrm{~h}$. The reaction was quenched with water and the layers were separated. Then the organic layer was washed with water and dried over $\mathrm{MgSO}_{4}$. After filtration, the filtrate was concentrated in vacuo and the crude product chromatographed through a silica gel column using an eluant of 1:1:4 EtOAc/ $\mathrm{CH}_{2} \mathrm{Cl}_{2} /$ hexane to afford $3.2 \mathrm{~g}(76 \%)$ of the desired product as a white solid. ${ }^{1} \mathrm{H}$ NMR $\left(\mathrm{CDCl}_{3} / 300 \mathrm{MHz}\right)$ (two main rotamers with approximately $1: 1$ ratio observed) $\delta$ 7.357.20(m, 3H), 7.16-7.11(m, 2H), 5.54 and 5.34(br s and br s, 1H), 4.42(dd, J=9.3, 5.7Hz, 0.5H), 3.93 (dd, $\mathrm{J}=11.2,4.6 \mathrm{~Hz}, 0.5 \mathrm{H}), 3.87(\mathrm{dd}, \mathrm{J}=11.8,5.0 \mathrm{~Hz}, 0.5 \mathrm{H}), 3.80-3.71(\mathrm{~m}, 1 \mathrm{H}), 3.73$ and $3.72(\mathrm{~s}$, and $\mathrm{s}, 3 \mathrm{H})$, 
$3.35-3.22(\mathrm{~m}, 2 \mathrm{H}), 3.00(\mathrm{dd}, \mathrm{J}=14.2,9.1 \mathrm{~Hz}, 0.5 \mathrm{H}), 2.72\left(\mathrm{~A}\right.$ of $\left.\mathrm{AB}, \mathrm{J}_{\mathrm{AB}}=14.4 \mathrm{~Hz}, 0.5 \mathrm{H}\right), 2.58(\mathrm{~A}$ of $\mathrm{AB}$, $\left.\mathrm{J}_{\mathrm{A}^{\prime} \mathrm{B}}=16.2 \mathrm{~Hz}, 0.5 \mathrm{H}\right), 2.53\left(\mathrm{~B}\right.$ of $\left.\mathrm{AB}, \mathrm{J}_{\mathrm{AB}}=13.5 \mathrm{~Hz}, 0.5 \mathrm{H}\right), 1.76\left(\mathrm{~B}\right.$ of $\left.\mathrm{AB}, \mathrm{J}_{\mathrm{AB}}=16.5 \mathrm{~Hz}, 0.5 \mathrm{H}\right), 1.44$ and $1.40(\mathrm{~s}$ and $\mathrm{s}, 9 \mathrm{H}), 0.03(\mathrm{~s}, 9 \mathrm{H}) ;{ }^{13} \mathrm{C} \mathrm{NMR}\left(\mathrm{CDCl}_{3} / 75 \mathrm{MHz}\right) \delta 170.1,169.9,168.1,167.3,155.6,137.8$, 136.0, 129.1, 128.9, 128.6, 127.2, 126.7, 79.4, 64.5, 61.1, 52.4, 52.1, 42.6, 41.8, 40.7, 35.8, 35.4, 34.3, 28.8, 28.2, -0.7, -2.1; IR (neat/NaCl) 3411, 2956, 1742, 1714, 1633, 1470, 1453, 1246, 1161, 1053, 854, 754, $700 \mathrm{~cm}^{-1}$; LRFAB MS (relative intensity) m/z 429 (59) $\mathrm{MLi}^{+}, 351$ (8) $\mathrm{MLi}^{+}-\mathrm{PhH}, 329$ (100) $\mathrm{MLi}^{+}-$ $\mathrm{Boc}+\mathrm{H}, 160$ (8); HRMS m/z calculated for [M+Li] $]^{+}$429.2397, found 429.2370 and 429.2380 .

2-[(2-tert-Butoxycarbonylaminoacetyl)methoxymethylamino]-3-phenylpropionic acid methyl ester (31a):

The silylated dipeptide substrate $(432 \mathrm{mg}, 1.02 \mathrm{mmol}$ ) was oxidized using the general procedure described above. In this experiment, $2.1 \mathrm{~F} / \mathrm{mol}$ of charge was passed through the cell. The crude product was chromatographed through silica gel using a gradient elution from 1:4 EtOAc/hexane to 1:1 EtOAc/hexane to afford $360 \mathrm{mg}(92 \%)$ of the desired product. ${ }^{1} \mathrm{H}$ NMR $\left(\mathrm{CDCl}_{3} / 300 \mathrm{MHz}\right)$ (two main rotamers with approximately $2: 1$ ratio observed) $\delta 7.28-7.12(\mathrm{~m}, 5 \mathrm{H}), 5.42(\mathrm{br} \mathrm{s}, 1 \mathrm{H}), 4.50(\mathrm{dd}, \mathrm{J}=9.6$, $5.4 \mathrm{~Hz}, 1 \mathrm{H}), 4.43(\mathrm{~d}, \mathrm{~J}=11.1 \mathrm{~Hz}, 1 \mathrm{H}), 3.99-3.95(\mathrm{~m}, 3 \mathrm{H}), 3.70$ and $3.69(\mathrm{~s}$ and $\mathrm{s}, 3 \mathrm{H}), 3.34(\mathrm{dd}, \mathrm{J}=14.1$, $5.4 \mathrm{~Hz}, 1 \mathrm{H}), 3.25-3.15(\mathrm{~m}, 1 \mathrm{H}), 3.19(\mathrm{~s}, 3 \mathrm{H}), 1.42$ and $1.40(\mathrm{~s}$ and $\mathrm{s}, 9 \mathrm{H}) ;{ }^{13} \mathrm{C} \mathrm{NMR}\left(\mathrm{CDCl}_{3} / 75 \mathrm{MHz}\right) \delta$ $170.9,169.9,156.0,137.7,129.3,128.9,127.0,79.9,79.3,61.0,55.9,52.6,42.5,35.3,28.5$; IR (neat/NaCl) 3423, 2978, 2928, 1739, 1711, 1498, 1451, 1435, 1364, 1273, 1169, 1023, 913, 752, $702 \mathrm{~cm}^{-}$ ${ }^{1}$; LRFAB MS (relative intensity) m/z 387 (100) $\mathrm{MLi}^{+}, 331$ (24) $\mathrm{MLi}^{+}-\mathrm{O}\left(\mathrm{CH}_{3}\right)_{2}, 313$ (7), $287(72) \mathrm{MLi}^{+}-$ Boc +H, 243 (6), 198 (13), 160 (33); HRFAB MS m/z calculated for [M+Li] 387.2107, found 387.2094.

3-Phenyl-2-\{[2-(2,2,2-trifluoro-acetylamino)acetyl]trimethylsilylmethylamino\}-propionic $\quad$ acid methyl ester (30b):

A $100 \mathrm{~mL}$ round bottom flask was charged with $\mathrm{Tfa}$ protected glycine $(170 \mathrm{mg}, 1 \mathrm{mmol})$ and ether $(3.0 \mathrm{~mL})$. To this mixture was added $\mathrm{PCl}_{5}(369 \mathrm{mg}, 1.25 \mathrm{mmol})$ and the resulting solution allowed to stir at room temperature for about 1 hour until all the $\mathrm{PCl}_{5}$ was dissolved. The solution was then decanted and washed with ether. The combined ether solution was concentrated under reduced pressure and the crude acid chloride obtained as a yellow solid.

A $250 \mathrm{~mL}$ round bottom flask was charged with the silylated phenyl alanine $(292 \mathrm{mg}, 1.1 \mathrm{mmol})$, triethyl amine $(0.35 \mathrm{~mL}, 2.5 \mathrm{mmol})$, and ether $(8.0 \mathrm{~mL})$. The Tfa-glycine acid chloride (crude) was dissolved in ether $(5 \mathrm{~mL})$ and cannulated into the reaction. An additional $1 \mathrm{~mL}$ of ether was used to ensure complete transfer of the acid chloride. The reaction mixture was stirred at room temperature for $12 \mathrm{~h}$ and then quenched with water. The layers were separated and the organic layer was washed with water and then dried over the $\mathrm{MgSO}_{4}$. After filtration, the filtrate was concentrated under reduced pressure. The residue was chromatographed through a silica gel column using an eluant of 1:3.5 hexane/EtOAc to afford $243 \mathrm{mg}(58 \%)$ of the silylated dipeptide product. ${ }^{1} \mathrm{H} \mathrm{NMR}\left(\mathrm{CDCl}_{3} / 300 \mathrm{MHz}\right)$ (two main rotamers with approximately $1: 1$ ratio were observed) $\delta 7.59(\mathrm{br} \mathrm{s}, 1 \mathrm{H}), 7.35-7.25(\mathrm{~m}, 3 \mathrm{H})$, 7.17-7.12 (m, 2H), $4.35(\mathrm{dd}, \mathrm{J}=9.9,4.8 \mathrm{~Hz}, 0.5 \mathrm{H}), 4.06-3.97(\mathrm{~m}, 0.33 \mathrm{H}), 3.96(\mathrm{dd}, \mathrm{J}=19.4,4.1 \mathrm{~Hz}, 1 \mathrm{H})$, $3.84(\mathrm{dd}, \mathrm{J}=9.9,5.4 \mathrm{~Hz}, 0.67 \mathrm{H}), 3.78$ and $3.78(\mathrm{~s}$ and $\mathrm{s}, 3 \mathrm{H}), 3.37-3.25(\mathrm{~m}, 2 \mathrm{H}), 3.07(\mathrm{dd}, \mathrm{J}=14.1,9.9 \mathrm{~Hz}$, $0.5 \mathrm{H}), 2.84\left(\mathrm{~A}\right.$ of $\left.\mathrm{AB}, \mathrm{J}_{\mathrm{AB}}=14.4 \mathrm{~Hz}, 0.5 \mathrm{H}\right), 2.58\left(\mathrm{~B}\right.$ of $\left.\mathrm{AB}, \mathrm{J}_{\mathrm{AB}}=14.4 \mathrm{~Hz}, 0.5 \mathrm{H}\right), 2.57$ (A of $\mathrm{AB}$, $\left.\mathrm{J}_{\mathrm{AB}}=16.5 \mathrm{~Hz}, 0.5 \mathrm{H}\right), 1.81\left(\mathrm{~B}\right.$ of $\left.\mathrm{AB}, \mathrm{J}_{\mathrm{AB}}=16.5 \mathrm{~Hz}, 0.5 \mathrm{H}\right), 0.07$ and $0.06(\mathrm{~s}$ and s, $9 \mathrm{H}) ;{ }^{13} \mathrm{C} \mathrm{NMR}\left(\mathrm{CDCl}_{3} / 75\right.$ $\mathrm{MHz}) \delta 170.0,169.7,166.1,165.4,137.7,136.1,129.4,129.2,129.0,127.8,127.2,65.1,61.8,53.0,52.6$, 41.9, 41.3, 41.0, 36.5, 35.4, 34.5, -0.5, -1.8; IR (neat/NaCl) 3270, 1728, 1642, 1249, 1160, $849 \mathrm{~cm}^{-1}$; LRFAB MS (relative intensity) m/z 425 (100) $\mathrm{MLi}^{+}, 406$ (11) $\mathrm{MLi}^{+}-\mathrm{F}, 206$ (6); HRFAB MS m/z calculated for $[\mathrm{M}+\mathrm{H}]^{+} 419.1615$, found 419.1626 .

(2S)-2-\{Methoxymethyl-[2-(2,2,2-trifluoroacetylamino)acetyl]-amino\}-3-phenyl-propionic methyl ester (31b):

acid 
The silylated dipeptide substrate $(251 \mathrm{mg}, 0.60 \mathrm{mmol})$ was oxidized using the general procedure outlined above. In this experiment, $2.1 \mathrm{~F} / \mathrm{mol}$ of charge was passed through the cell. The crude was chromatographed through silica gel using a gradient elution from 1:3 EtOAc/hexane to 1:1 EtOAc/hexane. The column afforded $157 \mathrm{mg}(70 \%)$ of the desired product along with $42 \mathrm{mg}(10 \%)$ of recovered starting material. ${ }^{1} \mathrm{H}$ NMR $\left(\mathrm{CDCl}_{3} / 300 \mathrm{MHz}\right) \delta 7.41(\mathrm{br} \mathrm{s}, 1 \mathrm{H}), 7.33-7.15(\mathrm{~m}, 5 \mathrm{H}), 4.62(\mathrm{dd}$, $\mathrm{J}=10.2,5.4 \mathrm{~Hz}, 1 \mathrm{H}), 4.46(\mathrm{dd}, \mathrm{J}=11.2,3.1 \mathrm{~Hz}, 1 \mathrm{H}), 4.19(\mathrm{~d}, \mathrm{~J}=4.2 \mathrm{~Hz}, 2 \mathrm{H}), 4.06(\mathrm{~d}, \mathrm{~J}=11.7 \mathrm{~Hz}, 1 \mathrm{H}), 3.76$ and $3.75(\mathrm{~s}$ and s, $3 \mathrm{H}), 3.40(\mathrm{dd}, \mathrm{J}=14.0,5.3 \mathrm{~Hz}, 1 \mathrm{H}), 3.32-3.16(\mathrm{~m}, 1 \mathrm{H}), 3.26$ and $3.11(\mathrm{~s}$ and $\mathrm{s}, 3 \mathrm{H}) ;{ }^{13} \mathrm{C}$ $\operatorname{NMR}\left(\mathrm{CDCl}_{3} / 75 \mathrm{MHz}\right) \delta 170.4,167.8,163.1,137.3,129.1,129.0,128.8,127.3,127.0,80.3,79.3,61.4$, 57.2, 56.1, 55.3, 52.8, 52.7, 41.6, 35.3, 34.7; IR (neat/NaCl) 3326, 1736, 1672, 1218, $1162 \mathrm{~cm}^{-1}$; LRFAB MS (relative intensity) m/z 383 (100) $\mathrm{MLi}^{+}, 339$ (3) $\mathrm{MLi}^{+}-\mathrm{CO}_{2}, 258$ (12), 198 (2); HRFAB MS m/z calculated for $[\mathrm{M}+\mathrm{H}]^{+} 377.1325$, found 377.1314 .

2-\{But-3-enyl-[2-(2,2,2-trifluoroacetylamino)acetyl]-amino\}-3-phenylpropionic acid methyl ester (32):

A $100 \mathrm{~mL}$ oven-dried round bottom flask was charged with the methoxylated substrate $(120 \mathrm{mg}$, $0.32 \mathrm{mmol})$, allylsilane $(0.51 \mu \mathrm{L}, 3.2 \mathrm{mmol})$, and ether $(9 \mathrm{~mL})$. The reaction mixture was cooled to $-40^{\circ} \mathrm{C}$ and $\mathrm{BF}_{3} \mathrm{Et}_{2} \mathrm{O}(44.6 \mu \mathrm{L}, 0.33 \mathrm{mmol})$ was added. The solution was allowed to stir at $-40^{\circ} \mathrm{C}$ for 1 hour, and then warmed to room temperature and stirred for another $16 \mathrm{~h}$. After this period, the mixture was concentrated under reduced pressure and the crude product chromatographed through a silica gel column using an eluant of 1:2 hexane/EtOAc to afford $87 \mathrm{mg}(71 \%)$ of the desired product along with $17 \mathrm{mg}$ $(14 \%)$ of recovered starting material. ${ }^{1} \mathrm{H} \mathrm{NMR}\left(\mathrm{CDCl}_{3} / 300 \mathrm{MHz}\right) \delta 7.55$ (br s, $\left.1 \mathrm{H}\right), 7.34-7.25(\mathrm{~m}, 3 \mathrm{H})$, 7.16-7.13 (m, 2H), 5.64 (ddt, J=16.8, 11.8, 6.0Hz, 1H), 5.08-5.01 (m, 2H), 4.11-4.06 (m, 3H), 3.77 and $3.77(\mathrm{~s}$ and $\mathrm{s}, 3 \mathrm{H}), 3.46\left(\mathrm{~A}\right.$ of $\left.\mathrm{ABX}, \mathrm{J}_{\mathrm{AB}}=14.0 \mathrm{~Hz}, \mathrm{~J}_{\mathrm{AX}}=5.1 \mathrm{~Hz}, 1 \mathrm{H}\right), 3.28\left(\mathrm{~B}\right.$ of $\mathrm{ABX}, \mathrm{J}_{\mathrm{AB}}=14.0 \mathrm{~Hz}$, $\left.\mathrm{J}_{\mathrm{BX}}=10.4 \mathrm{~Hz}, 1 \mathrm{H}\right), 3.10(\mathrm{dt}, \mathrm{J}=15.3,7.8 \mathrm{~Hz}, 1 \mathrm{H}), 2.55(\mathrm{dt}, \mathrm{J}=14.4,7.5 \mathrm{~Hz}, 1 \mathrm{H}), 2.12(\operatorname{app~q}, \mathrm{J}=7.5 \mathrm{~Hz}, 2 \mathrm{H})$; ${ }^{13} \mathrm{C} \mathrm{NMR}\left(\mathrm{CDCl}_{3} / 75 \mathrm{MHz}\right) \delta 170.2,169.9,166.4,157.4,157.3,137.6,135.9,134.7,133.6,129.3,129.2$, 129.1, 129.0, 127.8, 127.2, 118.5, 117.3, 63.4, 60.8, 53.1, 52.8, 48.9, 44.1, 41.7, 41.4, 35.6, 34.7, 32.6, 32.3; IR (neat/NaCl) 3306, 1728, 1652, 1211, $1160 \mathrm{~cm}^{-1}$; LRFAB MS (relative intensity) m/z 393 (100) $\mathrm{MLi}^{+}, 313$ (6), 219 (3), 160 (22), 91 (4); HRFAB MS m/z calculated for $[\mathrm{M}+\mathrm{H}]^{+}$387.1532, found 387.1522 .

General procedure for the preparation of nitrophenylsulfonyl N- $\beta$-silylated peptide substrate (35 \& 36):

To a $250 \mathrm{~mL}$ oven-dried round-bottom flask was added an amino acid methyl ester (15 mmol), triethylamine $(4.18 \mathrm{~mL}, 30 \mathrm{mmol})$, and dichloromethane $(100 \mathrm{~mL})$. The mixture was cooled to $0{ }^{\circ} \mathrm{C}$ with an ice bath and 2-nitrobenzenesulfonic chloride $(3.3 \mathrm{~g}, 15 \mathrm{mmol})$ was added slowly. The reaction solution was allowed to stir at room temperature for $12 \mathrm{~h}$ and then quenched with water. The reaction was transferred to a separatory funnel, the layers were separated, and the aqueous layer was extracted three times with dichloromethane. The combined organic layers were dried over $\mathrm{MgSO}_{4}$ and concentrated in vacuo. The crude product was carried forward without further purification. A $250 \mathrm{~mL}$ oven-dried round bottom flask was charged with the sulfonyl amino acid substrate $(\sim 15 \mathrm{mmol})$, (chloromethyl)trimethylsilane $(2.62 \mathrm{~mL}, 18.8 \mathrm{mmol}), \mathrm{KI}(3.1 \mathrm{~g}, 18.8 \mathrm{mmol}), \mathrm{K}_{2} \mathrm{CO}_{3}(2.07 \mathrm{~g}, 15 \mathrm{mmol})$ and DMF $(100 \mathrm{~mL})$. The suspension was stirred at $60{ }^{\circ} \mathrm{C}$ for $12 \mathrm{~h}$. The mixture was poured into water $(150 \mathrm{~mL})$ and extracted with ether $(4 \times 40 \mathrm{~mL})$. The extracts were combined, washed with water $(2 \times 30$

$\mathrm{mL})$ and brine $(2 \times 30 \mathrm{~mL})$, dried over $\mathrm{MgSO}_{4}$, and concentrated under reduced pressure. The residue was chromatographed through a silica gel column to give the product.

4-Methyl-2-[(4-nitrobenzenesulfonyl)trimethylsilanylmethylamino]-pentanoic acid methyl ester (35):

Compound 35 was prepared using the general procedure from L-leucine methyl ester $(3.32 \mathrm{~g}, 15$ mmol). The crude product was chromatographed through a silica gel column using an eluant of 1:3 
EtOAc/hexane. The column afforded $4.6 \mathrm{~g}$ (74\% for 2 steps) of the desired product along with $703 \mathrm{mg}$ (14\%) of recovered nitrophenylsulfonyl leucine methyl ester. ${ }^{1} \mathrm{H}$ NMR $\left(\mathrm{CDCl}_{3} / 300 \mathrm{MHz}\right) \delta 8.35(\mathrm{~d}$, $\mathrm{J}=6.8 \mathrm{~Hz}, 2 \mathrm{H}), 7.97(\mathrm{~d}, \mathrm{~J}=7.0 \mathrm{~Hz}, 2 \mathrm{H}), 4.56(\mathrm{dd}, \mathrm{J}=8.2,5.6 \mathrm{~Hz}, 1 \mathrm{H}), 3.44(\mathrm{~s}, 3 \mathrm{H}), 2.63(\mathrm{~d}, \mathrm{~J}=16.5 \mathrm{~Hz}, 1 \mathrm{H})$, $2.44(\mathrm{~d}, \mathrm{~J}=16.5 \mathrm{~Hz}, 1 \mathrm{H}), 1.77-1.67(\mathrm{~m}, 2 \mathrm{H}), 1.46(\mathrm{t}, \mathrm{J}=8.4 \mathrm{~Hz}, 1 \mathrm{H}), 0.98(\mathrm{~d}, \mathrm{~J}=4.8 \mathrm{~Hz}, 3 \mathrm{H}), 0.96(\mathrm{~d}$, $\mathrm{J}=5.1 \mathrm{~Hz}, 3 \mathrm{H}), 0.18(\mathrm{~s}, 9 \mathrm{H}) ;{ }^{13} \mathrm{C} \mathrm{NMR}\left(\mathrm{CDCl}_{3} / 75 \mathrm{MHz}\right) \delta 172.4,151.5,145.8,130.5,125.4,61.1,53.5$, 40.7, 38.1, 26.0, 24.3, 23.2, 0.5; IR (neat/NaCl) 2956, 1743, 1532, 1350, 1168, 852, $742 \mathrm{~cm}^{-1}$; LRFAB MS (relative intensity) $\mathrm{m} / \mathrm{z} 417$ (4) $\mathrm{MH}^{+}$, 401 (4) $\mathrm{MH}^{+}-16,154$ (100); HRFAB MS m/z calculated for $[\mathrm{M}+\mathrm{H}]^{+}$417.1516, found 417.1501.

\section{2-[(4-Nitro-benzenesulfonyl)trimethylsilanylmethylamino]propionic acid methyl ester (36):}

Compound 36 was prepared using the general procedure from L-alanine methyl ester $(2.09 \mathrm{~g}, 15$ mmol). The crude was chromatographed through silica gel column using an eluant of 1:4 EtOAc/hexane. The column afforded $3.36 \mathrm{~g}\left(60 \%\right.$ for 2 steps) of the desired product. ${ }^{1} \mathrm{H}$ NMR $\left(\mathrm{CDCl}_{3} / 300 \mathrm{MHz}\right) \delta 8.29$ $(\mathrm{d}, \mathrm{J}=9.0 \mathrm{~Hz}, 2 \mathrm{H}), 7.93(\mathrm{~d}, \mathrm{~J}=9.1 \mathrm{~Hz}, 2 \mathrm{H}), 4.58(\mathrm{dd}, \mathrm{J}=14.4,7.2 \mathrm{~Hz}, 1 \mathrm{H}), 3.46(\mathrm{~s}, 3 \mathrm{H}), 2.60(\mathrm{~d}, \mathrm{~J}=16.2 \mathrm{~Hz}$, $1 \mathrm{H}), 2.37(\mathrm{~d}, \mathrm{~J}=16.2 \mathrm{~Hz}, 1 \mathrm{H}), 1.33(\mathrm{~d}, \mathrm{~J}=7.5 \mathrm{~Hz}, 3 \mathrm{H}), 0.10$ and $0.09(\mathrm{~s}$ and $\mathrm{s}, 9 \mathrm{H}) ;{ }^{13} \mathrm{C} \mathrm{NMR}\left(\mathrm{CDCl}_{3} / 75\right.$ MHz) $\delta 171.1,150.0,144.7,129.0,124.1,57.0,52.3,36.8,16.4,-1.2$; IR (neat/NaCl) 3106, 2953, 1742, $1733,1538,1532,1350,1172,1151,1004,855,752,742,609 \mathrm{~cm}^{-1}$; LRFAB MS (relative intensity) $\mathrm{m} / \mathrm{z}$ 375 (61) $\mathrm{MH}^{+}, 359$ (65) $\mathrm{MH}^{+}-16,188$ (68) $\mathrm{M}^{+}-\mathrm{NO}_{2}-\mathrm{Ph}_{-} \mathrm{SO}_{2}-, 89$ (100); HRFAB MS m/z calculated for $[\mathrm{M}+\mathrm{H}]^{+} 375.1064$, found 375.1030 and $376.1068\left({ }^{13} \mathrm{C}\right)$.

General procedure for the deprotection of nitrophenylsulfonyl protecting group for compound 35 \& 36:

A $250 \mathrm{~mL}$ round bottom flask was charged with nitrophenylsulfonyl protected substrate (5 $\mathrm{mmol})$, potassium carbonate $(2.07 \mathrm{~g}, 15 \mathrm{mmol})$, benzene thiol $(565 \mu \mathrm{L}, 5.5 \mathrm{mmol})$, and aectonitrile $(100$ $\mathrm{mL}$ ). The mixture was stirred at room temperature for $12 \mathrm{~h}$. The resulting solution was concentrated under reduced pressure and redissolved in ether $(35 \mathrm{~mL})$. A $1 \mathrm{M}$ aqueous $\mathrm{HCl}$ solution was added dropwise to the solution until it reached a $\mathrm{pH}=2.0$. The mixture was then stirred for $10 \mathrm{~min}$ and the layers were separated. The organic layer was washed two times with water and the aqueous layers were combined. Potassium carbonate was added to neutralize the aqueous solution until the $\mathrm{pH}$ reached about 7.0. The aqueous phase was then extracted three times with ether and then the combined ether extracts dried over $\mathrm{MgSO}_{4}$ and concentrated in vacuo. The obtained crude product was very pure and could be used for the following steps without further purification.

2-[(2-Benzyloxycarbonylamino-3-phenylpropionyl)trimethylsilylmethylamino]-propionic acid methyl ester (37):

Silylated leucine methyl ester $(\sim 4.2 \mathrm{mmol})$ was obtained using the general procedure described above for deprotection of nitrophenylsulfonyl leucine substrate $(2.3 \mathrm{~g}, 5.3 \mathrm{mmol})$.

A $250 \mathrm{~mL}$ round bottom flask was charged with $\mathrm{N}$-(benzyloxycarbonyl)-phenylalanine $(1.5 \mathrm{~g}, 5.0$ mmol), N-methylmorpholine $(1.1 \mathrm{~mL}, 10 \mathrm{mmol})$, isobutylchloroformate $(0.713 \mathrm{~mL}, 5.5 \mathrm{mmol})$, and $\mathrm{CH}_{2} \mathrm{Cl}_{2}(90 \mathrm{~mL})$. The reaction mixture was stirred at $-15{ }^{\circ} \mathrm{C}$ for $25 \mathrm{~min}$. The silylated leucine substrate (crude) was dissolved in $\mathrm{CH}_{2} \mathrm{Cl}_{2}(10 \mathrm{~mL})$ and cannulated into the above solution. An additional $2 \mathrm{~mL}$ of $\mathrm{CH}_{2} \mathrm{Cl}_{2}$ was used to ensure complete transfer of the substrate. The mixture was then warmed up to room temperature and stirred for $12 \mathrm{~h}$. The reaction was quenched with water and the layers were separated. The organic layer was then washed with water before being dried over the $\mathrm{MgSO}_{4}$. After filtration, the filtrate was concentrated in vacuo and the residue chromatographed through a silica gel column using an eluant of 1:4 EtOAc/ hexane to afford $1.7 \mathrm{~g}$ (67\% for 2 steps) of the silylated dipeptide product. ${ }^{1} \mathrm{H}$ NMR $\left(\mathrm{CDCl}_{3} / 300 \mathrm{MHz}\right.$ ) (two main rotamers with approximately 1:1 ratio observed) $\delta 7.43-7.09(\mathrm{~m}, 10 \mathrm{H}), 5.73$ (br dd, J=8.6, 5.0Hz, 1H), 5.14 and 5.11 ( $\mathrm{s}$ and s, 2H), 4.99 (dd, J=15.9, 7.2Hz, 0.5H), 4.78 (dd, J=14.8, $7.6 \mathrm{~Hz}, 0.5 \mathrm{H}), 4.47(\mathrm{dd}, \mathrm{J}=13.8,6.9 \mathrm{~Hz}, 0.5 \mathrm{H}), 3.86(\mathrm{dd}, \mathrm{J}=14.1,6.9 \mathrm{~Hz}, 0.5 \mathrm{H}), 3.73$ and $3.66(\mathrm{~s}$ and $\mathrm{s}, 3 \mathrm{H})$, 3.06-3.03 (m, 2H), $2.70\left(\mathrm{~A}\right.$ of $\left.\mathrm{AB}, \mathrm{J}_{\mathrm{AB}}=16.8 \mathrm{~Hz}, 0.5 \mathrm{H}\right), 2.64\left(\mathrm{~A}\right.$ of $\left.\mathrm{AB}, \mathrm{J}_{\mathrm{AB}}=15.0 \mathrm{~Hz}, 0.5 \mathrm{H}\right), 2.40(\mathrm{~B}$ of $\mathrm{AB}$, 
$\left.\mathrm{J}_{\mathrm{AB}}=14.7 \mathrm{~Hz}, 0.5 \mathrm{H}\right), 2.30\left(\mathrm{~B}\right.$ of $\left.\mathrm{AB}, \mathrm{J}_{\mathrm{AB}}=16.5 \mathrm{~Hz}, 0.5 \mathrm{H}\right), 1.41(\mathrm{~d}, \mathrm{~J}=6.9 \mathrm{~Hz}, 1.5 \mathrm{H}), 1.01(\mathrm{~d}, \mathrm{~J}=7.2 \mathrm{~Hz}, 1.5 \mathrm{H})$, 0.13 and 0.07 (s and s, 9H); ${ }^{13} \mathrm{C}$ NMR $\left(\mathrm{CDCl}_{3} / 75 \mathrm{MHz}\right) \delta 171.3,171.2,170.1,155.6,155.4,136.6,136.5$, $136.2,129.8,129.6,128.8,128.6,128.5,128.4,128.1,128.0,128.0,127.2,127.1,66.8,66.8,57.7,55.9$, 52.6, 52.4, 52.2, 52.1, 40.5, 40.3, 39.5, 35.9, 15.4, 13.8, -0.6, -2.1; IR (neat/NaCl) 3294, 2952, 1743, $1717,1636,1454,1245,1052,848,747,699 \mathrm{~cm}^{-1}$; LRFAB MS (relative intensity) $\mathrm{m} / \mathrm{z} 471(40) \mathrm{MH}^{+}$, 455 (48) $\mathrm{M}^{+}-\mathrm{CH}_{3}, 347$ (12) $\mathrm{M}^{+}-\mathrm{CH}_{3}-\mathrm{PhCH}_{2} \mathrm{O}, 190$ (100); HRFAB MS m/z calculated for [M] 470.2237 , found $[\mathrm{M}+\mathrm{H}]^{+} 471.2315$, and $472.2339\left({ }^{13} \mathrm{C}\right)$.

2-[(3-Benzyloxycarbonylaminopropionyl)trimethylsilylmethylamino]-4-methylpentanoic acid methyl ester (38):

Silylated leucine methyl ester $(\sim 5.2 \mathrm{mmol})$ was obtained using the general procedure described above for deprotection of the nitrophenylsulfonyl leucine substrate $(3.0 \mathrm{~g}, 7.2 \mathrm{mmol})$.

A $250 \mathrm{~mL}$ round bottom flask was charged with $\mathrm{N}$-(benzyloxycarbonyl)- $\beta$-alanine $(1.16 \mathrm{~g}, 5.2$ $\mathrm{mmol})$, N-methylmorpholine $(1.1 \mathrm{~mL}, 10 \mathrm{mmol})$, isobutylchloroformate $(0.742 \mathrm{~mL}, 5.72 \mathrm{mmol})$, and $\mathrm{CH}_{2} \mathrm{Cl}_{2}(100 \mathrm{~mL})$. The reaction mixture was stirred at $-15^{\circ} \mathrm{C}$ for $25 \mathrm{~min}$. The silylated leucine substrate was dissolved in $\mathrm{CH}_{2} \mathrm{Cl}_{2}(10 \mathrm{~mL})$ and then added to the solution above with the use of a cannulation. An additional $2 \mathrm{~mL}$ of $\mathrm{CH}_{2} \mathrm{Cl}_{2}$ was used to ensure complete transfer of the silylated leucine. Following the cannulation, the reaction was warmed to room temperature and stirred for $12 \mathrm{~h}$. The reaction was quenched with water and the layers were separated. The organic layer was then washed with water before being dried over $\mathrm{MgSO}_{4}$. After filtration, the filtrate was concentrated in vacuo and the resulting residue chromatographed through a silica gel column using an eluant of 1:2.5 EtOAc/ hexane to afford $1.82 \mathrm{~g}$ ( $58 \%$ for 2 steps) of the silylated dipeptide product. ${ }^{1} \mathrm{H} \mathrm{NMR}\left(\mathrm{CDCl}_{3} / 300 \mathrm{MHz}\right)$ (two main rotamers with approximately $2: 1$ ratio observed) $\delta 7.35-7.29(\mathrm{~m}, 5 \mathrm{H}), 5.57(\mathrm{br} \mathrm{s}, 1 \mathrm{H}), 5.08(\mathrm{~s}, 2 \mathrm{H}), 4.36(\mathrm{dd}, \mathrm{J}=8.2$, $6.4 \mathrm{~Hz}, 0.67 \mathrm{H}), 4.15(\mathrm{t}, \mathrm{J}=6.8 \mathrm{~Hz}, 0.33 \mathrm{H}), 3.69$ and 3.67 (s and $\mathrm{s}, 3 \mathrm{H}), 3.50$ (app. sextet, $\mathrm{J}=5.7 \mathrm{~Hz}, 2 \mathrm{H}$ ), $0.98(\mathrm{~d}, \mathrm{~J}=16.5 \mathrm{~Hz}, 0.33 \mathrm{H}), 2.66-2.44(\mathrm{~m}, 3.67 \mathrm{H}), 1.97-1.75(\mathrm{~m}, 1 \mathrm{H}), 1.66-1.52(\mathrm{~m}, 2 \mathrm{H}), 0.93$ (app. $\mathrm{t}$, $\mathrm{J}=6.8 \mathrm{~Hz}, 6 \mathrm{H}), 0.13$ and 0.04 (s and $\mathrm{s}, 9 \mathrm{H}) ;{ }^{13} \mathrm{C} \mathrm{NMR}\left(\mathrm{CDCl}_{3} / 75 \mathrm{MHz}\right) \delta 171.8,171.4,171.3,156.6$, $136.9,128.6,128.1,128.1,66.6,58.7,58.5,52.5,52.1,39.5,38.7,38.2,37.1,36.9,35.4,33.9,33.2,25.2$, 24.7, 23.0, 23.0, 22.5, 22.3, -0.4, -1.4; IR (neat/NaCl) 3338, 2955, 1732, 1634, 1504, 1455, 1248, 1002, $850,697 \mathrm{~cm}^{-1}$; LRFAB MS (relative intensity) m/z 443 (100) $\mathrm{MLi}^{+}, 91$ (12); HRFAB MS m/z calculated for $[\mathrm{M}+\mathrm{Li}]^{+} 443.2554$, found 443.2548 .

2-[(2-Benzyloxycarbonylamino-3-phenylpropionyl)methoxymethylamino]-propionic acid methyl ester:

The silylated dipeptide substrate $(1.15 \mathrm{~g}, 2.55 \mathrm{mmol})$ was oxidized using the general procedure outlined above. In this experiment, $2.1 \mathrm{~F} / \mathrm{mol}$ of charge was passed through the cell. The crude product was chromatographed through silica gel using a gradient elution from 1:3 EtOAc/hexane to 1:1.5 EtOAc/hexane. The column afforded $919 \mathrm{mg}(88 \%)$ of the desired product. ${ }^{1} \mathrm{H} \mathrm{NMR}\left(\mathrm{CDCl}_{3} / 300 \mathrm{MHz}\right)$ $\delta 7.38-7.18(\mathrm{~m}, 10 \mathrm{H}), 5.54(\mathrm{~d}, \mathrm{~J}=5.7 \mathrm{~Hz}, 1 \mathrm{H}), 5.10\left(\mathrm{~A}\right.$ of $\left.\mathrm{AB}, \mathrm{J}_{\mathrm{AB}}=12.0 \mathrm{~Hz}, 1 \mathrm{H}\right), 5.04\left(\mathrm{~B}\right.$ of $\mathrm{AB}, \mathrm{J}_{\mathrm{AB}}=12.3 \mathrm{~Hz}$, $1 \mathrm{H}), 4.93(\mathrm{q}, \mathrm{J}=7.4 \mathrm{~Hz}, 1 \mathrm{H}), 4.50\left(\mathrm{~A}^{\prime}\right.$ of $\left.\mathrm{AB}, \mathrm{J}_{\mathrm{AB}}=11.4 \mathrm{~Hz}, 1 \mathrm{H}\right), 4.50-4.43(\mathrm{~m}, 1 \mathrm{H}), 4.40(\mathrm{~B}$ of $\mathrm{AB}$, $\left.\mathrm{J}_{\mathrm{AB}}=10.8 \mathrm{~Hz}, 1 \mathrm{H}\right), 3.68(\mathrm{~s}, 3 \mathrm{H}), 3.24(\mathrm{~s}, 3 \mathrm{H}), 3.08(\mathrm{dd}, \mathrm{J}=13.2,7.5 \mathrm{~Hz}, 1 \mathrm{H}), 2.97(\mathrm{dd}, \mathrm{J}=13.2,6.3 \mathrm{~Hz}, 1 \mathrm{H})$, $1.41(\mathrm{~d}, \mathrm{~J}=6.6 \mathrm{~Hz}, 3 \mathrm{H}) ;{ }^{13} \mathrm{C} \mathrm{NMR}\left(\mathrm{CDCl}_{3} / 75 \mathrm{MHz}\right) \delta 172.4,171.9,155.7,136.1,129.8,129.7,128.7$, 128.3, 128.2, 127.2, 78.1, 67.0, 55.5, 54.0, 52.7, 52.4, 40.2, 14.9; IR (neat/NaCl) 3311, 2947, 1740, 1720, 1656, 1496, 1452, 1239, 1080, 744, $699 \mathrm{~cm}^{-1}$; LRFAB MS (relative intensity) m/z 435 (100) $\mathrm{MLi}^{+}, 313$ (20), 160 (76); HRMS m/z calculated for [M+Li] $]^{+}$435.2107, found 435.2092.

2-[(2-Benzyloxycarbonylamino-3-phenylpropionyl)phenylsulfanylmethylamino]-propionic acid methyl ester (39):

To a $50 \mathrm{~mL}$ oven-dried round bottom flask was added the methoxylated substrate (135 $\mathrm{mg}, 0.32$ mmol), benzene thiol $(97 \mu \mathrm{L}, 0.96 \mathrm{mmol})$, and ether $(2 \mathrm{~mL}) . \mathrm{BF}_{3} \mathrm{Et}_{2} \mathrm{O}(8 \mu \mathrm{L}, 0.06 \mathrm{mmol})$ was added to this mixture and the reaction was allowed to stir at room temperature for $24 \mathrm{~h}$. The solution was 
concentrated in vacuo and the crude product was chromatographed through silica gel using 1:2 EtOAc/hexane as eluant. The column afforded $102 \mathrm{mg}(64 \%)$ of the desired product along with $38 \mathrm{mg}$ $(28 \%)$ of recovered startimg material. ${ }^{1} \mathrm{H} \mathrm{NMR}\left(\mathrm{CDCl}_{3} / 300 \mathrm{MHz}\right)$ (two main rotamers with approximately $4: 1$ ratio were observed) $\delta 7.49-7.42(\mathrm{~m}, 1 \mathrm{H}), 7.41-7.22(\mathrm{~m}, 13 \mathrm{H}), 7.14-7.11(\mathrm{~m}, 1 \mathrm{H})$, $5.67(\mathrm{~d}, \mathrm{~J}=8.7 \mathrm{~Hz}, 0.2 \mathrm{H}), 5.43(\mathrm{~d}, \mathrm{~J}=8.1 \mathrm{~Hz}, 0.8 \mathrm{H}), 5.07-5.00(\mathrm{~m}, 2 \mathrm{H}), 4.89-4.83(\mathrm{~m}, 0.2 \mathrm{H}), 4.78-4.68(\mathrm{~m}$, $0.8 \mathrm{H}), 4.56\left(\mathrm{~A}\right.$ of $\left.\mathrm{AB}, \mathrm{J}_{\mathrm{AB}}=14.1 \mathrm{~Hz}, 1 \mathrm{H}\right), 4.40\left(\mathrm{~B}\right.$ of $\left.\mathrm{AB}, \mathrm{J}_{\mathrm{AB}}=14.1 \mathrm{~Hz}, 1 \mathrm{H}\right), 4.39-4.34(\mathrm{~m}, 1 \mathrm{H}), 3.68$ and 3.53(s and s, $3 \mathrm{H}), 3.02-2.88(\mathrm{~m}, 2 \mathrm{H}), 1.43$ and $1.40(\mathrm{~s}$ and $\mathrm{s}, 2.4 \mathrm{H}), 0.95$ and $0.93(\mathrm{~s}$ and $\mathrm{s}, 0.6 \mathrm{H}) ;{ }^{13} \mathrm{C} \mathrm{NMR}$ $\left(\mathrm{CDCl}_{3} / 75 \mathrm{MHz}\right) \delta 171.7,171.4,155.4,136.5,136.1,135.8,133.6,132.7,131.8,129.8,129.7,129.6$, 129.1, 128.9, 128.7, 128.3, 128.1, 127.5, 127.4, 127.2, 66.9, 55.1, 54.5, 53.6, 52.7, 52.6, 52.4, 48.9, 39.9, 14.7; IR (neat/NaCl) 3305, 3025, 1740, 1656, 1438, 1220, 1049, 744, $696 \mathrm{~cm}^{-1}$; LRFAB MS (relative intensity) $\mathrm{m} / \mathrm{z} 513$ (100) $\mathrm{MLi}^{+}, 313$ (11), 160 (51); HRMS m/z calculated for [M+Li] ${ }^{+}$513.2036, found 513.2040 .

2-[(3-Benzyloxycarbonylaminopropionyl)methoxymethylamino]-4-methylpentanoic acid methyl ester:

The silylated dipeptide substrate $(1.46 \mathrm{~g}, 3.34 \mathrm{mmol})$ was oxidized using the general procedure outlined above. In this experiment, $2.3 \mathrm{~F} / \mathrm{mol}$ of charge was passed through the electrolysis cell. The crude product was chromatographed through silica gel using 1:3 EtOAc/hexane as eluant. The column afforded $1.14 \mathrm{~g}(87 \%)$ of the desired product. ${ }^{1} \mathrm{H} \mathrm{NMR}\left(\mathrm{CDCl}_{3} / 300 \mathrm{MHz}\right) \delta 7.35-7.28(\mathrm{~m}, 5 \mathrm{H}), 5.54(\mathrm{br}$ $\mathrm{s}, 1 \mathrm{H}), 5.08(\mathrm{~s}, 2 \mathrm{H}), 5.02(\mathrm{dd}, \mathrm{J}=9.2,5.2 \mathrm{~Hz}, 1 \mathrm{H}), 4.68(\mathrm{~d}, \mathrm{~J}=10.8 \mathrm{~Hz}, 1 \mathrm{H}), 4.52(\mathrm{~d}, \mathrm{~J}=10.5 \mathrm{~Hz}, 1 \mathrm{H}), 3.68(\mathrm{~s}$, $3 \mathrm{H}), 3.54-3.48(\mathrm{~m}, 2 \mathrm{H}), 3.28(\mathrm{~s}, 3 \mathrm{H}), 2.70(\mathrm{t}, \mathrm{J}=5.6 \mathrm{~Hz}, 2 \mathrm{H}), 1.83-1.73(\mathrm{~m}, 1 \mathrm{H}), 1.68-1.57(\mathrm{~m}, 2 \mathrm{H}), 0.93$, $0.92,0.91$ and $0.90(\mathrm{~s}, \mathrm{~s}, \mathrm{~s}$ and $\mathrm{s}, 6 \mathrm{H}) ;{ }^{13} \mathrm{C} \mathrm{NMR}\left(\mathrm{CDCl}_{3} / 75 \mathrm{MHz}\right) \delta 173.4,172.6,156.5,136.8,128.6$, 128.1, 128.1, 77.8, 66.6, 55.4, 54.8, 52.3, 38.8, 38.5, 36.9, 36.8, 33.2, 24.8, 24.6, 23.0, 22.9, 22.1, 21.9; IR (neat/NaCl) 3347, 2955, 1722, 1661, 1514, 1435, 1391, 1242, 1076, 754, $698 \mathrm{~cm}^{-1}$; LRFAB MS (relative intensity) $\mathrm{m} / \mathrm{z} 401$ (100) $\mathrm{MLi}^{+}, 91$ (20); HRFAB MS m/z calculated for $[\mathrm{M}+\mathrm{Li}]^{+}$401.2264, found 401.2255.

\section{2-[(3-Benzyloxycarbonylaminopropionyl)phenylsulfanylmethylamino]-4-methylpentanoic acid methyl ester (40):}

To a $50 \mathrm{~mL}$ oven-dried round bottom flask was added the methoxylated substrate (189 $\mathrm{mg}, 0.48$ $\mathrm{mmol})$, benzene thiol $(197 \mu \mathrm{L}, 1.9 \mathrm{mmol})$, and ether $(5 \mathrm{~mL}) . \mathrm{BF}_{3} \mathrm{Et}_{2} \mathrm{O}(20 \mu \mathrm{L}, 0.16 \mathrm{mmol})$ was added to this mixture and the reaction was allowed to stir at room temperature for $16 \mathrm{~h}$. The solution was concentrated in vacuo and the crude product was chromatographed through silica gel using 1:1 EtOAc/hexane as eluant. The column afforded $170 \mathrm{mg}(75 \%)$ of the desired product along with $34 \mathrm{mg}$ of an unknown byproduct. ${ }^{1} \mathrm{H} \mathrm{NMR}\left(\mathrm{CDCl}_{3} / 300 \mathrm{MHz}\right.$ ) (two main rotamers with approximately 9:1 ratio were observed) $\delta$ 7.47-7.42 (m, 2H), 7.34-7.24 (m, 8H), 5.49 (br t, J=6.0Hz, 1H), 5.08 (br s, 2H), 4.93 (td, $\mathrm{J}=8.7,3.0 \mathrm{H}, 1 \mathrm{H}), 4.73\left(\mathrm{~A}\right.$ of $\left.\mathrm{AB}, \mathrm{J}_{\mathrm{AB}}=14.1 \mathrm{~Hz}, 0.9 \mathrm{H}\right), 4.66\left(\mathrm{~B}\right.$ of $\left.\mathrm{AB}, \mathrm{J}_{\mathrm{AB}}=14.1 \mathrm{~Hz}, 0.9 \mathrm{H}\right), 4.35$ (br t, $\mathrm{J}=6.9 \mathrm{~Hz}, 0.2 \mathrm{H}), 3.69$ and $3.62(\mathrm{~s}$ and $\mathrm{s}, 3 \mathrm{H}), 3.49(\mathrm{dd}, \mathrm{J}=11.4,6.0 \mathrm{~Hz}, 0.2 \mathrm{H}), 3.40(\mathrm{dd}, \mathrm{J}=11.6,6.2 \mathrm{~Hz}$, $1.8 \mathrm{H}), 2.62-2.41(\mathrm{~m}, 2 \mathrm{H}), 1.90-1.80(\mathrm{~m}, 1 \mathrm{H}), 1.78-1.54(\mathrm{~m}, 2 \mathrm{H}), 0.94$ and $0.92(\mathrm{~s}$ and $\mathrm{s}, 6 \mathrm{H}) ;{ }^{13} \mathrm{C} \mathrm{NMR}$ $\left(\mathrm{CDCl}_{3} / 75 \mathrm{MHz}\right) \delta 172.7,171.9,171.3,156.4,136.7,133.4,133.2,131.5,129.5,129.0,128.5,128.4$, $128.1,128.0,127.3,66.5,57.0,55.6,53.0,52.6,52.3,48.6,38.4,38.1,36.7,33.8,33.5,25.1,24.6,22.8$, 22.7, 22.1, 14.3; IR (neat/NaCl) 3350, 2955, 1738, 1716, 1661, 1511, 1439, 1413, 1256, 1002, 748, 695

$\mathrm{cm}^{-1}$; LRFAB MS (relative intensity) m/z 473 (1) $\mathrm{MH}^{+}, 363$ (8) $\mathrm{MH}^{+}-\mathrm{PhS}, 91$ (100); HRFAB MS m/z calculated for $[\mathrm{M}+\mathrm{H}]^{+}$473.2110, found 473.2093 and 474.2159 .

\section{2-(\{2-[2-(2-tert-Butoxycarbonylaminoacetylamino)acetylamino]acetyl\}-trimethylsilylmethyl- amino)-3-phenylpropionic acid methyl ester (41):}

A $250 \mathrm{~mL}$ oven-dried round bottom flask was charged with Boc-Gly-Gly-OH (162 mg, 0.7 mmol), silylated H-Gly-Phe-OMe (155 mg, $0.48 \mathrm{mmol}$ ), HATU (280 mg, $0.74 \mathrm{mmol}), 2$,4,6-collidine $(154 \mu \mathrm{L}, 1.16 \mathrm{mmol})$ and $\mathrm{DMF}(8.5 \mathrm{~mL})$. The reaction mixture was allowed to stir at room temperature 
for $16 \mathrm{~h}$ and then quenched with water. The layers were separated and the aqueous layer was extracted three times with EtOAc. The combined organic layers were dried over $\mathrm{MgSO}_{4}$ and concentrated in vacuo. The crude product was chromatographed through silica gel using a gradient elution from 1:2 EtOAc/hexane to $10 \% \mathrm{MeOH} /$ EtOAc. The column afforded $137 \mathrm{mg}(53 \%)$ of the desired product. ${ }^{1} \mathrm{H}$ NMR $\left(\mathrm{CDCl}_{3} / 300 \mathrm{MHz}\right)$ (two main rotamers were observed in an approximately 1:1 ratio) $\delta 7.31-7.10$ $(\mathrm{m}, 5 \mathrm{H}), 5.47$ (br s, 1H), $4.50(\mathrm{dd}, \mathrm{J}=9.6,5.1 \mathrm{~Hz}, 0.5 \mathrm{H}), 4.03-3.91(\mathrm{~m}, 3.5 \mathrm{H}), 3.84-3.74(\mathrm{~m}, 3 \mathrm{H}), 3.72$ and $3.71(\mathrm{~s}$ and $\mathrm{s}, 3 \mathrm{H}), 3.38-3.20(\mathrm{~m}, 1.5 \mathrm{H}), 3.06-2.98(\mathrm{~m}, 0.5 \mathrm{H}), 2.75\left(\mathrm{~A}\right.$ of $\left.\mathrm{AB}, \mathrm{J}_{\mathrm{AB}}=14.1 \mathrm{~Hz}, 0.5 \mathrm{H}\right), 2.61(\mathrm{~A}$ of $\left.\mathrm{AB}, \mathrm{J}_{\mathrm{AB}}=16.5 \mathrm{HZ}, 0.5 \mathrm{H}\right), 2.52\left(\mathrm{~B}\right.$ of $\left.\mathrm{AB}, \mathrm{J}_{\mathrm{AB}}=14.7 \mathrm{~Hz}, 0.5 \mathrm{H}\right), 1.76\left(\mathrm{~B}\right.$ of $\left.\mathrm{AB}, \mathrm{J}_{\mathrm{AB}}=16.5 \mathrm{~Hz}, 0.5 \mathrm{H}\right), 1.42$ and 1.41 (s and s, 9H), 0.02 and $0.01\left(\mathrm{~s}\right.$ and s, 9H); ${ }^{13} \mathrm{C} \mathrm{NMR}\left(\mathrm{CDCl}_{3} / 75 \mathrm{MHz}\right) \delta 170.3,170.1,168.8$, 168.4, 167.7, 167.0, 159.3, 137.8, 136.2, 129.3, 129.1, 128.9, 127.5, 127.0, 80.3, 64.8, 61.5, 52.8, 52.4, $44.2,42.8,42.6,41.7,41.1,40.9,36.2,35.4,34.4,28.5,-0.5,-1.8$; IR (neat/ $\mathrm{NaCl}) 3323,1746,1703$, $1699,1694,1661,1652,1435,1172 \mathrm{~cm}^{-1}$; LRFAB MS (relative intensity) m/z 543 (27) $\mathrm{MLi}^{+}, 518$ (2), 474 (4), 443 (15) $\mathrm{MLi}^{+}-\mathrm{Boc}+\mathrm{H}, 412$ (4), 260 (83), 160 (100); HRFAB MS m/z calculated for [M+Li] ${ }^{+}$ 543.2826, found 543.2836.

2-(\{2-[2-(2-tert-Butoxycarbonylaminoacetylamino)acetylamino]-acetyl\}-methoxymethylamino)-3phenylpropionic acid methyl ester (42):

The silylated tetrapeptide substrate $(128 \mathrm{mg}, 0.24 \mathrm{mmol})$ was oxidized using the general procedure described above. In this experimtent, $2.1 \mathrm{~F} / \mathrm{mol}$ of charge was passed through the cell. The crude product was chromatographed through silica gel using a gradient elution from EtOAc to 5\% $\mathrm{MeOH} / \mathrm{EtOAc}$ to afford $92 \mathrm{mg}(78 \%)$ of the desired product. ${ }^{1} \mathrm{H} \mathrm{NMR}\left(\mathrm{CDCl}_{3} / 300 \mathrm{MHz}\right) \delta 7.28-7.13(\mathrm{~m}$, $5 \mathrm{H}), 5.51$ (br s, 1H), 4.52-4.46 (m, 2H), $4.10(\mathrm{dd}, \mathrm{J}=12.0,4.5 \mathrm{~Hz}, 1 \mathrm{H}), 4.03-3.98(\mathrm{~m}, 4 \mathrm{H}), 3.93-3.69$ (m, 2H), $3.69(\mathrm{~s}, 3 \mathrm{H}), 3.33(\mathrm{dd}, \mathrm{J}=14.1,5.4 \mathrm{~Hz}, 1 \mathrm{H}), 3.28-3.11(\mathrm{~m}, 1 \mathrm{H}), 3.21$ and $3.21(\mathrm{~s}$ and $\mathrm{s}, 3 \mathrm{H}), 1.42(\mathrm{~s}$, $9 \mathrm{H}) ;{ }^{13} \mathrm{C} \mathrm{NMR}\left(\mathrm{CDCl}_{3} / 75 \mathrm{MHz}\right) \delta 170.5,170.2,169.2,168.9,156.1137 .3,129.5,129.0,128.6,126.8$, 80.1, 79.0, 60.9, 55.6, 52.4, 44.1, 42.6, 41.1, 35.0, 28.2; IR (neat/NaCl) 3331, 1741, 1652, 1660, 1531, 1280, 1248, $1170 \mathrm{~cm}^{-1}$; LRFAB MS (relative intensity) m/z 501 (100) $\mathrm{MLi}^{+}, 445$ (10) $\mathrm{MLi}^{+}-\mathrm{C}_{4} \mathrm{H}_{8}, 401$ (48) $\mathrm{MLi}^{+}-\mathrm{Boc}+\mathrm{H}, 192$ (32), 91 (24); HRFAB MS m/z calculated for $[\mathrm{M}+\mathrm{Li}]^{+}$501.2537, found 501.2546.

General procedure for coupling protected, N-terminus amino acids to N-trimethylsilylmethyl-Lphenylalanine methyl ester (27). A variation of the procedure used to synthesize 30a:

A $250 \mathrm{~mL}$ round bottom flask was flame-dried and filled with argon. It was then charged with dichloromethane, N-methylmorpholine (NMM), and isobutylchloroformate. The resulting solution was cooled to $-20^{\circ} \mathrm{C}$. Next, the protected, $\mathrm{N}$-terminus amino acid was added to $20 \mathrm{~mL}$ of dichloromethane and dripped into the aforementioned solution over a period of approximately one hour via an addition funnel and with stirring. After complete addition of N-terminus amino acid, the N-trimethylsilylmethyl-Lphenylalanine methyl ester derivative (27) was dissolved in $20 \mathrm{~mL}$ of dichloromethane and added to the reaction solution. The solution was allowed to warm to room temperature as it stirred for $18 \mathrm{~h}$. The reaction was then quenched with brine and extracted with diethyl ether four times. The ethereal extracts were combined and concentrated in vacuo. The crude product was then chromatographed (unless otherwise noted below) through a silica gel column with a stepwise elution. The elution started with $25 \%$ diethyl ether in hexanes and increased to $60 \%$ diethyl ether in steps of $5 \%$ ether per each additional column volume of eluent passed through the column. Amounts of reagents and yields for each coupling reaction are specified below.

2-[N-(2-tert-Butoxycarbonylaminoacetyl)-N-trimethylsilanylmethylamino]-3-phenylpropionic acid methyl ester (44a):

Compound 44a was prepared using the general procedure outlined above. Dichloromethane (50 $\mathrm{mL}), \mathrm{NMM}(0.99 \mathrm{~mL}, 9.0 \mathrm{mmol})$, and isobutylchloroformate $(0.58 \mathrm{~mL}, 4.5 \mathrm{mmol})$ were initially combined. N-(tert-butoxycarbonyl)-glycine $(0.786 \mathrm{~g}, 4.49 \mathrm{mmol})$ and the N-trimethylsilylmethyl-L- 
phenylalanine methyl ester derivative $(27)(0.829 \mathrm{~g}, 3.11 \mathrm{mmol})$ were then added. The crude product was purified by recrystallization from hexanes to afford $1.01 \mathrm{~g}(77.1 \%)$ of pure product from two crops of white, needle-like crystals. ${ }^{1} \mathrm{H}$ NMR $\left(\mathrm{CDCl}_{3} / 300 \mathrm{MHz}\right)$ (Two main rotamers with approximately $1: 1$ ratio were observed.) $\delta 7.35-7.20(\mathrm{~m}, 3 \mathrm{H}), 7.16-7.11(\mathrm{~m}, 2 \mathrm{H}), 5.54$ and 5.34 (br s and br s, 1H), 4.42 (dd, $\mathrm{J}=9.3,5.7 \mathrm{~Hz}, 0.5 \mathrm{H}), 3.93(\mathrm{dd}, \mathrm{J}=11.2,4.6 \mathrm{~Hz}, 0.5 \mathrm{H}), 3.87(\mathrm{dd}, \mathrm{J}=11.8,5.0 \mathrm{~Hz}, 0.5 \mathrm{H}), 3.80-3.71(\mathrm{~m}, 1 \mathrm{H})$, 3.73 and $3.72(\mathrm{~s}$, and s, $3 \mathrm{H}), 3.35-3.22(\mathrm{~m}, 2 \mathrm{H}), 3.00(\mathrm{dd}, \mathrm{J}=14.2,9.1 \mathrm{~Hz}, 0.5 \mathrm{H}), 2.72\left(\mathrm{~A}\right.$ of $\mathrm{AB}, \mathrm{J}_{\mathrm{AB}}=14.4$ $\mathrm{Hz}, 0.5 \mathrm{H}), 2.58\left(\mathrm{~A}\right.$ of $\left.\mathrm{AB}, \mathrm{J}_{\mathrm{AB}}=16.2 \mathrm{~Hz}, 0.5 \mathrm{H}\right), 2.53\left(\mathrm{~B}\right.$ of $\left.\mathrm{AB}, \mathrm{J}_{\mathrm{AB}}=13.5 \mathrm{~Hz}, 0.5 \mathrm{H}\right), 1.76(\mathrm{~B}$ of $\mathrm{AB}$, $\left.\mathrm{J}_{\mathrm{AB}}=16.5 \mathrm{~Hz}, 0.5 \mathrm{H}\right), 1.44$ and 1.40 (s and s, 9H), $0.03(\mathrm{~s}, 9 \mathrm{H}) ;{ }^{13} \mathrm{C} \mathrm{NMR}\left(\mathrm{CDCl}_{3} / 75 \mathrm{MHz}\right) \delta 170.1,169.9$, 168.1, 167.3, 155.6, 137.8, 136.0, 129.1, 128.9, 128.6, 127.2, 126.7, 79.4, 64.5, 61.1, 52.4, 52.1, 42.6, 41.8, 40.7, 35.8, 35.4, 34.3, 28.8, 28.2, -0.7, -2.1; IR (neat/NaCl) 3411, 2956, 1742, 1714, 1633, 1470, 1453, 1246, 1161, 1053, 854, 754, $700 \mathrm{~cm}^{-1}$; LRFAB MS (relative intensity) $\mathrm{m} / \mathrm{z} 429$ (59) $\mathrm{MLi}^{+}, 351$ (8) $\mathrm{MLi}^{+}-\mathrm{PhH}, 329$ (100) $\mathrm{MLi}^{+}-\mathrm{Boc}+\mathrm{H}, 160$ (8); HRFAB MS m/z calculated for $[\mathrm{M}+\mathrm{Li}]^{+}$429.2397, found 429.2370 and 429.2380 .

\section{2-[N-(2-tert-Butoxycarbonylaminopropionyl)-N-trimethylsilanylmethylamino]-3-phenylpropionic acid methyl ester (44b):}

Compound 44b was prepared using the general procedure outlined above. Dichloromethane (35 $\mathrm{mL}), \mathrm{NMM}(0.62 \mathrm{~mL}, 5.6 \mathrm{mmol})$, and isobutylchloroformate $(0.36 \mathrm{~mL}, 2.8 \mathrm{mmol})$ were initially combined. N-(tert-butoxycarbonyl)-L-alanine $(0.719 \mathrm{~g}, 3.80 \mathrm{mmol})$ and the N-trimethylsilylmethyl-Lphenylalanine methyl ester derivative $(27)(0.503 \mathrm{~g}, 1.89 \mathrm{mmol})$ were then added. The crude product was chromatographed as described above to afford $0.440 \mathrm{~g} \mathrm{(53 \% )}$ of pure product, which was a very viscous, colorless liquid. ${ }^{1} \mathrm{H}$ NMR $\left(\mathrm{CDCl}_{3} / 500 \mathrm{MHz}\right)$ (Two rotamers with an approximate ratio of 1:1 were observed). $\delta 7.32-7.16(\mathrm{~m}, 5 \mathrm{H}), 5.49(\mathrm{br} \mathrm{d}, \mathrm{J}=8.0 \mathrm{~Hz}, 1 \mathrm{H}$ of one rotamer), $5.02(\mathrm{~m}, 2 \mathrm{H}$ of one rotamer or $1 \mathrm{H}$ of each), 4.40 (quartet of doublets, app quintet, $\mathrm{J} \approx 7 \mathrm{~Hz}, 1 \mathrm{H}$ of one rotamer), 4.33 (quartet of doublets, app quintet, $\mathrm{J} \approx 7 \mathrm{~Hz}, 1 \mathrm{H}$ of one rotamer), 3.77 (s, $3 \mathrm{H}$ of one rotamer), ca 3.77 (1H of one rotamer buried under s), $3.74\left(\mathrm{~s}, 3 \mathrm{H}\right.$ of one rotamer), 3.37 (A of $\mathrm{ABX}, \mathrm{J}_{\mathrm{AB}}=14.0 \mathrm{~Hz}, \mathrm{~J}_{\mathrm{AX}}=4.5 \mathrm{~Hz}, 1 \mathrm{H}$ of one rotamer), $3.35\left(\mathrm{dd}, \mathrm{J}=4.5,14.5,1 \mathrm{H}\right.$ of one rotamer), $3.29\left(\mathrm{~B}\right.$ of $\mathrm{ABX}, \mathrm{J}_{\mathrm{AB}}=14.0 \mathrm{~Hz}, \mathrm{~J}_{\mathrm{BX}}=11.0 \mathrm{~Hz}, 1 \mathrm{H}$ of one rotamer), 3.01 (dd, $\mathrm{J}=9.5,14.0 \mathrm{~Hz}, 1 \mathrm{H}$ of one rotamer), 2.73 ( $\mathrm{A}$ of $\mathrm{AB}, \mathrm{J}_{\mathrm{AB}}=16.5 \mathrm{~Hz}, 1 \mathrm{H}$ of one rotamer), $2.70\left(\mathrm{~A}\right.$ of $\mathrm{AB}, \mathrm{J}_{\mathrm{AB}}=14.0 \mathrm{~Hz}, 1 \mathrm{H}$ of one rotamer), $2.53\left(\mathrm{~B}\right.$ of $\mathrm{AB}, \mathrm{J}_{\mathrm{AB}}=14.0 \mathrm{~Hz}, 1 \mathrm{H}$ of one rotamer), 1.87 ( $\mathrm{B}$ of $\mathrm{AB}, \mathrm{J}_{\mathrm{AB}}=17.0 \mathrm{~Hz}, 1 \mathrm{H}$ of one rotamer), 1.43 (s, $9 \mathrm{H}$ of one rotamer), 1.41 (s, 9H of one rotamer), 1.26 $(\mathrm{d}, \mathrm{J}=6.5 \mathrm{H}, 3 \mathrm{H}$ of one rotamer), $0.74(\mathrm{~d}, \mathrm{~J}=7.0 \mathrm{~Hz}, 3 \mathrm{H}$ of one rotamer), 0.07 ( $\mathrm{s}, 9 \mathrm{H}$ of one rotamer), 0.06 (s, 9H of one rotamer); ${ }^{13} \mathrm{C} \mathrm{NMR}\left(\mathrm{CDCl}_{3} / 125 \mathrm{MHz}\right) \delta 173.0,171.7,170.5,170.3,155.0,154.9,138.0$, 136.8, 129.5, 129.4, 129.0, 128.7, 127.3, 126.9, 79.6, 79.3, 64.9, 62.5, 52.5, 52.2, 46.8, 45.1, 42.4, 36.5, 35.9, 34.7, 28.5, 28.4, 19.3, 18.4, -0.5, -2.2; IR (neat/NaCl) 3428, 3334, 3108, 3087, 3064, 3028, 2977 , 2951, 2899, 1949, 1747-1694, 1656-1634, 1605, 1586, 1495, 1454, 1366, 1166, 1050, 1028, 968, 922, 858, 752, $702 \mathrm{~cm}^{-1}$; LREI MS (relative intensity) $\mathrm{m} / \mathrm{z} 436$ (10) $\mathrm{M}^{+}, 421$ (42), 365 (100), 363 (10), 347 (27), 130 (67); HREI MS m/z calculated for $\mathrm{M}^{+} 436.2394$, found 436.2384 and $437.2408\left({ }^{13} \mathrm{C}\right)$.

\section{2-[N-(2-tert-Butoxycarbonylamino-3-phenylpropionyl)-N-trimethylsilanylmethylamino]-3- phenylpropionic acid methyl ester (44c):}

Compound $44 \mathbf{c}$ was prepared using the general procedure outlined above. Dichloromethane (50 $\mathrm{mL})$, NMM $(0.99 \mathrm{~mL}, 9.0 \mathrm{mmol})$, and isobutylchloroformate $(0.59 \mathrm{~mL}, 4.5 \mathrm{mmol})$ were initially combined. N-(tert-nutoxycarbonyl)-L-phenylalanine $(1.199 \mathrm{~g}, 4.519 \mathrm{mmol})$ and the Ntrimethylsilylmethyl-L-phenylalanine methyl ester derivative (27) $(0.809 \mathrm{~g}, 3.04 \mathrm{mmol})$ were then added. The crude product was chromatographed as described above to afford $0.855 \mathrm{~g} \mathrm{(55 \% )}$ of pure product, which was a very viscous, colorless liquid. ${ }^{1} \mathrm{H}$ NMR $\left(\mathrm{CDCl}_{3} / 300 \mathrm{MHz}\right)$ (Two main rotamers with approximately 1:1 ratio were observed.) $\delta 7.33-6.95(\mathrm{~m}, 8 \mathrm{H}), 7.04-6.95(\mathrm{~m}, 2 \mathrm{H}), 5.21$ (br d, J=9.0 Hz, $0.5 \mathrm{H}$ ), 5.10 (dd, J=4.5, $9.9 \mathrm{~Hz}, 0.5 \mathrm{H}), 4.81$ (br d, J=9.9 Hz, 0.5H), 4.67 (ddd, app quartet, J $\approx 7 \mathrm{~Hz}, 0.5 \mathrm{H}$ ), 4.48 (dt, J=4.5, $9.9 \mathrm{~Hz}, 0.5 \mathrm{H}), 3.79$ (dd, J=5.4, $9.0 \mathrm{~Hz}, 0.5 \mathrm{H}), 3.74(\mathrm{~s}, 1.5 \mathrm{H}), 3.71(\mathrm{~s}, 1.5 \mathrm{H}), 3.40$ (dd, $\mathrm{J}=5.4,14.1 \mathrm{~Hz}, 0.5 \mathrm{H}), 3.29(\mathrm{dd}, \mathrm{J}=5.1,14.1 \mathrm{~Hz}, 0.5 \mathrm{H}), 3.08-2.70(\mathrm{~m}, 3 \mathrm{H}), 2.63$ (dd, J=9.9, $14.4 \mathrm{~Hz}$, 
$0.5 \mathrm{H}), 2.52(\mathrm{~d}, \mathrm{~J}=14.4 \mathrm{~Hz}, 0.5 \mathrm{H}), 2.16(\mathrm{dd}, \mathrm{J}=4.8,14.1 \mathrm{~Hz}, 0.5 \mathrm{H}), 1.89(\mathrm{~d}, \mathrm{~J}=16.2 \mathrm{~Hz}, 0.5 \mathrm{H}), 1.34(\mathrm{~s}$, $4.5 \mathrm{H}), 1.27(\mathrm{~s}, 4.5 \mathrm{H}), 0.06(\mathrm{~s}, 4.5 \mathrm{H}), 0.03(\mathrm{~s}, 4.5 \mathrm{H}) ;{ }^{13} \mathrm{C} \mathrm{NMR}\left(\mathrm{CDCl}_{3} / 75 \mathrm{MHz}\right) \delta 171.7,170.3,170.2$, $169.9,154.7,154.5,137.9,136.8,136.7,136.6,129.5,129.1,128.7,128.4,128.2,128.0,126.9,126.5$, $126.5,126.2,79.1,79.1,64.2,62.0,52.0,51.8,51.7,49.9,41.3,39.9,37.9,36.3,35.5,34.6,28.1,28.0$, 0.7, -2.4; IR (neat/NaCl) 3300, 2975, 2947, 1743, 1706, 1642, 1634, 1494, 1454, 1245, 1169, 850, 760, $699 \mathrm{~cm}^{-1}$; LRFAB MS (relative intensity) m/z 519 (53) $\mathrm{MLi}^{+}, 419$ (100) $\mathrm{MLi}^{+}-\mathrm{Boc}+\mathrm{H}, 206$ (18), 91 (40); HRFAB MS m/z calculated for $[\mathrm{M}+\mathrm{Li}]^{+} 519.2867$, found 519.2880 and $520.2915\left({ }^{13} \mathrm{C}\right)$.

General procedure for preparative electrolyses of silylated dipeptides 30a, 44b, and 44c for comparison with the parallel electrolyses:

A three-neck round bottom flask was flame-dried and fitted with two carbon electrodes, one of which (the anode) bore a piece of RVC (approximately $1 \mathrm{~cm} \times 1 \mathrm{~cm} \times 1 \mathrm{~cm}$ ) on its tip. The flask was charged with a solution of anhydrous alcohol containing $\mathrm{Bu}_{4} \mathrm{NBF}_{4}(100 \mathrm{mM})$ and dipeptide substrate $(10$ $\mathrm{mM}$ ). The electrodes of the reaction cell were connected to an Arbin power supply, and a constant current electrolysis $(8 \mathrm{~mA})$ was carried out with stirring until 2.2 Faradays/mole of electrons had been passed through the cell. After the reaction was complete, the alcoholic reaction solvent was removed in vacuo and the electrolyte was removed by precipitation with diethyl ether and filtration. The crude material recovered after removal of the ethereal filtrate was chromatographed through a silica gel column with a stepwise elution. The elution started with $25 \%$ diethyl ether in hexanes and increased to $60 \%$ ether in steps of 5\% ether per each additional column volume of eluent passed through the column. Amounts of reagents and yields for all preparative electrolyses are specified below. Purity percentages are calculated from the molar ratios of products to starting materials observed in the proton NMR spectra.

Note: The purpose of doing these preparative electrolyses was to obtain pure products for full characterization. Therefore, difficult chromatographic separations on silica gel necessitated the sacrifice of yield for purity in some cases. More accurate yield data are reported in the parallel synthesis experiment described below.

\section{2-[N-(2-tert-Butoxycarbonylaminoacetyl)-N-methoxymethylamino]-3-phenylpropionic acid methyl ester (31a):}

The methoxy ether from 30a was prepared using the general procedure described above. The substrate (30a) $(0.080 \mathrm{~g}, 0.19 \mathrm{mmol})$, tetrabutylammonium tetrafluoroborate $(0.615 \mathrm{~g}, 1.89 \mathrm{mmol})$, and anhydrous methanol $(19 \mathrm{~mL})$ were combined to make the electrolysis reaction solution. The crude product was chromatographed as described above to afford $0.061 \mathrm{~g}(82 \%)$ of pure product (the lower yield than that reported above was most likely due to the change in scale). The spectral data matched that reported above.

\section{2-[N-(2-tert-Butoxycarbonylaminoacetyl)-N-ethoxymethylamino]-3-phenylpropionic acid methyl ester (made from 30a):}

The ethoxy ether from 30a was prepared using the general procedure described above. The substrate (30a) $(0.080 \mathrm{~g}, 0.19 \mathrm{mmol})$, tetrabutylammonium tetrafluoroborate $(0.621 \mathrm{~g}, 1.89 \mathrm{mmol})$, and anhydrous ethanol $(19 \mathrm{~mL})$ were combined to make the electrolysis reaction solution. The crude product was chromatographed as described above to afford $0.068 \mathrm{~g}(91 \%)$ of pure product. ${ }^{1} \mathrm{H} \mathrm{NMR}\left(\mathrm{CDCl}_{3} / 300\right.$ MHz) $\delta 7.31-7.15(\mathrm{~m}, 5 \mathrm{H}), 5.42(\mathrm{br} \mathrm{s}, 1 \mathrm{H}), 4.58$ (dd, J=9.8, 5.8Hz, 1H), $4.50(\mathrm{~d}, \mathrm{~J}=11.4 \mathrm{~Hz}, 1 \mathrm{H}), 4.08$ (d, $\mathrm{J}=11.7 \mathrm{~Hz}, 1 \mathrm{H}), 4.02(\mathrm{~d}, \mathrm{~J}=4.5 \mathrm{~Hz}, 2 \mathrm{H}), 3.72(\mathrm{~s}, 3 \mathrm{H}), 3.48-3.33(\mathrm{~m}, 3 \mathrm{H}), 3.21(\mathrm{dd}, \mathrm{J}=14.1,9.9 \mathrm{~Hz}, 1 \mathrm{H})$, $1.45(\mathrm{~s}, 9 \mathrm{H}), 1.13(\mathrm{t}, \mathrm{J}=7.0 \mathrm{~Hz}, 3 \mathrm{H}) ;{ }^{13} \mathrm{C} \mathrm{NMR}\left(\mathrm{CDCl}_{3} / 75 \mathrm{MHz}\right) \delta 170.9,169.7,156.6,156.4,155.9$, $151.5,137.7,129.3,128.8,127.0,126.7,77.6,63.9,63.8,60.6,52.6,42.5,35.3,28.6,20.0,15.0$; IR (neat/NaCl) 3423, 2969, 1740, 1715, 1667, 1494, 1454, 1365, 1242, 1166, 1091, 750, $699 \mathrm{~cm}^{-1}$; LRFAB MS (relative intensity) $\mathrm{m} / \mathrm{z} 401$ (50) $\mathrm{MLi}^{+}, 345$ (20) $\mathrm{MLi}^{+}-\mathrm{C}_{4} \mathrm{H}_{8}, 301$ (49) $\mathrm{MLi}^{+}-\mathrm{Boc}+\mathrm{H}, 160$ (66), 89 (100); HRMS m/z calculated for [M+Li] ${ }^{+} 401.2264$, found 401.2248 and $402.2279\left({ }^{13} \mathrm{C}\right)$. 
The propoxy ether from 30a was prepared using the general procedure described above. The substrate (30a) $(0.083 \mathrm{~g}, 0.20 \mathrm{mmol})$, tetrabutylammonium tetrafluoroborate $(0.624 \mathrm{~g}, 1.89 \mathrm{mmol})$, and anhydrous n-propanol $(19 \mathrm{~mL})$ were combined to make the electrolysis reaction solution. The crude product was chromatographed as described above to afford $0.059 \mathrm{~g}(74 \%)$ of $>98 \%$ pure product. ${ }^{1} \mathrm{H}$ NMR $\left(\mathrm{CDCl}_{3} / 300 \mathrm{MHz}\right) . \delta 7.31-7.16(\mathrm{~m}, 5 \mathrm{H}), 5.42(\mathrm{br} \mathrm{s}, 1 \mathrm{H}), 4.59(\mathrm{dd}, \mathrm{J}=5.7,9.6 \mathrm{~Hz}, 1 \mathrm{H}), 4.51(\mathrm{~A}$ of $\left.\mathrm{AB}, \mathrm{J}_{\mathrm{AB}}=11.4 \mathrm{~Hz}, 1 \mathrm{H}\right), 4.09\left(\mathrm{~B}\right.$ of $\left.\mathrm{AB}, \mathrm{J}_{\mathrm{AB}}=11.4 \mathrm{~Hz}, 1 \mathrm{H}\right), 4.02(\mathrm{~d}, \mathrm{~J}=3.9 \mathrm{~Hz}, 2 \mathrm{H}), 3.72(\mathrm{~s}, 3 \mathrm{H}), 3.40-3.17$ $(\mathrm{m}, 4 \mathrm{H}), 1.52$ (sextet, J=7.5 Hz, 2H), $1.45(\mathrm{~s}, 9 \mathrm{H}), 0.87(\mathrm{t}, \mathrm{J}=7.2 \mathrm{~Hz}, 3 \mathrm{H}) ;{ }^{13} \mathrm{C} \mathrm{NMR}\left(\mathrm{CDCl}_{3} / 125 \mathrm{MHz}\right) \delta$ $170.9,169.8,155.9,137.7,129.3,128.8,127.0,79.8,77.8,70.2,60.6,52.5,42.5,35.3,28.5,22.8,10.7$; IR (neat/NaCl) 3424, 3086, 3062, 3028, 2973, 2935, 2877, 1954, 1744-1667, 1604, 1584, 1496, 1455, 1366, 1247, 1169, 1087, 1048, 1026, 982, 949, 909, 865, 822, 754, 702, $650 \mathrm{~cm}^{-1}$; LRFAB MS (relative intensity) m/z 415 (71) $\mathrm{MLi}^{+}, 359$ (31), 329 (10), 315 (100), 243 (15), 198 (18), 91 (68), 89 (51); HRFAB MS $\mathrm{m} / \mathrm{z}$ calculated for $[\mathrm{M}+\mathrm{Li}]^{+} 415.2420$, found 415.2423 and $416.2460\left({ }^{13} \mathrm{C}\right)$.

2-[N-(2-tert-Butoxycarbonylaminoacetyl)-N-(n-butoxy)methylamino]-3-phenylpropionic acid methyl ester (made from 30a):

The butoxy ether from 30a was prepared using the general procedure described above. The substrate (30a) (0.082 g, $0.19 \mathrm{mmol})$, tetrabutylammonium tetrafluoroborate $(0.623 \mathrm{~g}, 1.89 \mathrm{mmol})$, and anhydrous n-butanol $(19 \mathrm{~mL})$ were combined to make the electrolysis reaction solution. The crude product was chromatographed twice as described above to afford $0.019 \mathrm{~g}$ of $\sim 85 \%$ pure product. ${ }^{1} \mathrm{H}$ NMR $\left(\mathrm{CDCl}_{3} / 300 \mathrm{MHz}\right) \delta$ 7.31-7.16 (m, 5H), 5.43 (br s, 1H), $4.58(\mathrm{dd}, \mathrm{J}=9.4,5.6 \mathrm{~Hz}, 1 \mathrm{H}), 4.50$ (d, J=11.4 Hz, $1 \mathrm{H}), 4.08(\mathrm{~d}, \mathrm{~J}=11.4 \mathrm{~Hz}, 1 \mathrm{H}), 4.02(\mathrm{~d}, \mathrm{~J}=4.2 \mathrm{~Hz}, 2 \mathrm{H}), 3.71(\mathrm{~s}, 3 \mathrm{H}), 3.44-3.53(\mathrm{~m}, 3 \mathrm{H}), 3.21$ (dd, J=14.1, $9.6 \mathrm{~Hz}, 1 \mathrm{H}), 1.53-1.39(\mathrm{~m}, 2 \mathrm{H}), 1.46(\mathrm{~s}, 9 \mathrm{H}), 1.44-1.24(\mathrm{~m}, 2 \mathrm{H}), 0.89(\mathrm{t}, \mathrm{J}=7.2 \mathrm{~Hz}, 3 \mathrm{H}) ;{ }^{13} \mathrm{C}$ NMR $\left(\mathrm{CDCl}_{3} / 75 \mathrm{MHz}\right) \delta 170.9,169.7,155.9,137.7,129.3,128.8,127.0,79.9,77.8,68.3,66.9,60.7,52.6$, 42.5, 35.3, 31.6, 28.5, 19.4, 14.0; IR (neat/NaCl) 3423, 2930, 1743, 1715, 1667, 1454, 1365, 1244, 1169 , 1088, 752, $699 \mathrm{~cm}^{-1}$; LRFAB MS (relative intensity) m/z 429 (15) $\mathrm{MLi}^{+}, 329$ (13) $\mathrm{MLi}^{+}-\mathrm{Boc}+\mathrm{H}, 202$ (13), 160 (68), 89 (100); HRMS $\mathrm{m} / \mathrm{z}$ calculated for $[\mathrm{M}+\mathrm{Li}]^{+} 429.2577$, found 429.2568 and $430.2605\left({ }^{13} \mathrm{C}\right)$.

2-[N-(2-tert-Butoxycarbonylaminopropionyl)-N-methoxymethylamino]-3-phenylpropionic acid methyl ester (made from $44 \mathrm{~b}$ ):

The methoxy ether from 44b was prepared using the general procedure described above. The substrate (44b) $(0.100 \mathrm{~g}, 0.229 \mathrm{mmol})$, tetrabutylammonium tetrafluoroborate $(0.755 \mathrm{~g}, 2.30 \mathrm{mmol})$, and anhydrous methanol $(23 \mathrm{~mL})$ were combined to make the electrolysis reaction solution. The crude product was chromatographed as described above to afford $0.073 \mathrm{~g}(81 \%)$ of pure product. ${ }^{1} \mathrm{H}$ NMR $\left(\mathrm{CDCl}_{3} / 300 \mathrm{MHz}\right) \delta 7.30-7.15(\mathrm{~m}, 5 \mathrm{H}), 5.31$ (br d, J=6.6 Hz, 1H), 4.60 (quartet of doublets, app quintet, $\mathrm{J} \approx 7 \mathrm{~Hz}, 1 \mathrm{H}), 4.43\left(\mathrm{~A}\right.$ of $\left.\mathrm{AB}, \mathrm{J}_{\mathrm{AB}}=11.4 \mathrm{~Hz}, 1 \mathrm{H}\right)$, ca 4.43 (methine buried under $\mathrm{A}$ of $\mathrm{AB}$ ), 4.15 (B of $\mathrm{AB}$, $\left.\mathrm{J}_{\mathrm{AB}}=11.1 \mathrm{~Hz}, 1 \mathrm{H}\right), 3.73(\mathrm{~s}, 3 \mathrm{H}), 3.39\left(\mathrm{~A}\right.$ of $\left.\mathrm{ABX}, \mathrm{J}_{\mathrm{AB}}=14.1 \mathrm{~Hz}, \mathrm{~J}_{\mathrm{AX}}=5.4 \mathrm{~Hz}, 1 \mathrm{H}\right), 3.24(\mathrm{~B}$ of $\mathrm{ABX}$, $\left.\mathrm{J}_{\mathrm{AB}}=14.1 \mathrm{~Hz}, \mathrm{~J}_{\mathrm{BX}}=10.2 \mathrm{~Hz}, 1 \mathrm{H}\right), 3.24(\mathrm{~s}, 3 \mathrm{H}), 1.43(\mathrm{~s}, 9 \mathrm{H}), 1.26(\mathrm{~d}, \mathrm{~J}=6.9 \mathrm{~Hz}, 3 \mathrm{H}) ;{ }^{13} \mathrm{C} \mathrm{NMR}\left(\mathrm{CDCl}_{3} / 125\right.$ $\mathrm{MHz}) \delta 173.8,170.9,155.2,137.8,129.5,128.7,127.0,79.8,79.6,60.3,55.8,52.5,46.8,35.1,28.5$, 19.8; IR (neat/NaCl) 3425, 3335, 3086, 3062, 3027, 2978, 2932, 2845, 1957, 1744-1652, 1604, 1584, $1495,1455,1391,1366,1165,1056,1022,981,913,875,855,753,702 \mathrm{~cm}^{-1}$; LRFAB MS (relative intensity) m/z 401 (100) $\mathrm{MLi}^{+}, 345$ (29), 301 (42), 198 (20), 89 (80); HRFAB MS m/z calculated for $[\mathrm{M}+\mathrm{Li}]^{+} 401.2264$, found 401.2252 and $402.2281\left({ }^{13} \mathrm{C}\right)$.

2-[N-(2-tert-Butoxycarbonylaminopropionyl)-N-ethoxymethylamino]-3-phenylpropionic acid methyl ester (made from $44 \mathrm{~b}$ ):

The ethoxy ether from 44b was prepared using the general procedure described above. The substrate (44b) (0.099 g, $0.23 \mathrm{mmol})$, tetrabutylammonium tetrafluoroborate (0.748 g, $2.27 \mathrm{mmol})$, and 
anhydrous ethanol $(23 \mathrm{~mL})$ were combined to make the electrolysis reaction solution. The crude product was chromatographed as described above to afford $0.063 \mathrm{~g}(67 \%)$ of pure product. ${ }^{1} \mathrm{H} \mathrm{NMR}\left(\mathrm{CDCl}_{3} / 500\right.$ $\mathrm{MHz}) . \delta 7.28-7.16(\mathrm{~m}, 5 \mathrm{H}), 5.34(\mathrm{~d}, \mathrm{~J}=7.5 \mathrm{~Hz}, 1 \mathrm{H}), 4.60$ (quartet of doublets, app. quintet, $\mathrm{J} \approx 7 \mathrm{~Hz}, 1 \mathrm{H}$ ), $4.49\left(\mathrm{~A}\right.$ of $\left.\mathrm{AB}, \mathrm{J}_{\mathrm{AB}}=11.5 \mathrm{~Hz}, 1 \mathrm{H}\right), 4.46(\mathrm{dd}, \mathrm{J}=5.0,9.5 \mathrm{~Hz}, 1 \mathrm{H}), 4.23\left(\mathrm{~B}\right.$ of $\left.\mathrm{AB}, \mathrm{J}_{\mathrm{AB}}=11.0 \mathrm{~Hz}, 1 \mathrm{H}\right), 3.71(\mathrm{~s}$, $3 \mathrm{H}$ ), 3.52 (quartet of doublets, app quintet, $\mathrm{J} \approx 7 \mathrm{~Hz}, 1 \mathrm{H}$ ), $3.39\left(\mathrm{~A}\right.$ of $\mathrm{ABX}, \mathrm{J}_{\mathrm{AB}}=14.0 \mathrm{~Hz}, \mathrm{~J}_{\mathrm{AX}}=5.5 \mathrm{~Hz}, 1 \mathrm{H}$ ), 3.32 (quartet of doublets, $\mathrm{J}=6.5,8.5 \mathrm{~Hz}, 1 \mathrm{H}), 3.24\left(\mathrm{~B}\right.$ of $\left.\mathrm{ABX}, \mathrm{J}_{\mathrm{AB}}=14 \mathrm{~Hz}, \mathrm{~J}_{\mathrm{BX}}=9.5 \mathrm{~Hz}, 1 \mathrm{H}\right), 1.43(\mathrm{~s}, 9 \mathrm{H})$, $1.26(\mathrm{~d}, \mathrm{~J}=7.0 \mathrm{~Hz}, 3 \mathrm{H}), 1.12(\mathrm{t}, \mathrm{J}=7.0 \mathrm{~Hz}, 3 \mathrm{H}) ;{ }^{13} \mathrm{C} \mathrm{NMR}\left(\mathrm{CDCl}_{3} / 125 \mathrm{MHz}\right) \delta 173.7,170.9,155.1,137.8$, $129.5,128.7,126.9,79.7,78.1,63.7,60.2,52.4,46.8,35.0,28.5,19.9,15.0$; IR (neat/NaCl) 3428, 3343, 3108, 3087, 3063, 3029, 2979, 2873, 1952, 1755-1644, 1605, 1585, 1538-1434, 1392, 1361, 1277, 1092 , $1025,982,925,907,875,856,753,701 \mathrm{~cm}^{-1}$; LRFAB MS (relative intensity) m/z 415 (55) $\mathrm{MLi}^{+}, 313$ (18), 160 (100), 136 (11), 89 (16); HRFAB MS m/z calculated for [M+Li] $]^{+}$415.2420, found 415.2411 and $416.2453\left({ }^{13} \mathrm{C}\right)$.

2-[N-(2-tert-Butoxycarbonylaminopropionyl)-N-(n-propoxy)methylamino]-3-phenylpropionic acid methyl ester (44b):

The propoxy ether from 44b was prepared using the general procedure described above. The substrate (44b) (0.099 g, $0.23 \mathrm{mmol})$, tetrabutylammonium tetrafluoroborate (0.748 g, $2.27 \mathrm{mmol})$, and anhydrous n-propanol $(23 \mathrm{~mL})$ were combined to make the electrolysis reaction solution. The crude product was chromatographed as described above to afford $0.058 \mathrm{~g}(61 \%)$ of $>97 \%$ pure product. ${ }^{1} \mathrm{H}$ NMR $\left(\mathrm{CDCl}_{3} / 500 \mathrm{MHz}\right)$. $\delta$ 7.28-7.16 (m, 5H), 5.34 (br d, J=7.5 Hz, 1H), 4.61 (quartet of doublets, app quintet, $\mathrm{J} \approx 7 \mathrm{~Hz}, 1 \mathrm{H}), 4.49\left(\mathrm{~A}\right.$ of $\left.\mathrm{AB}, \mathrm{J}_{\mathrm{AB}}=10.5 \mathrm{~Hz}, 1 \mathrm{H}\right)$, ca $4.48(\mathrm{dd}, \mathrm{J}=5.5,9.5 \mathrm{~Hz}, 1 \mathrm{H}), 4.27(\mathrm{~B}$ of $\mathrm{AB}$, $\left.\mathrm{J}_{\mathrm{AB}}=11.0 \mathrm{~Hz}, 1 \mathrm{H}\right), 3.71(\mathrm{~s}, 3 \mathrm{H}), 3.43$ (triplet of doublets, app quartet, $\mathrm{J} \approx 7 \mathrm{~Hz}, 1 \mathrm{H}$ ), ca 3.39 (A of $\mathrm{ABX}$, $\left.\mathrm{J}_{\mathrm{AB}}=14.0 \mathrm{~Hz}, \mathrm{~J}_{\mathrm{AX}}=5.5 \mathrm{~Hz}, 1 \mathrm{H}\right), 3.25-3.19(\mathrm{~m}, 2 \mathrm{H}), 1.50$ (sextet, $\left.\mathrm{J}=7.5 \mathrm{~Hz}, 2 \mathrm{H}\right), 1.43(\mathrm{~s}, 9 \mathrm{H}), 1.26(\mathrm{~d}, \mathrm{~J}=7.0$ $\mathrm{Hz}, 3 \mathrm{H}), 0.87(\mathrm{t}, \mathrm{J}=7.5 \mathrm{~Hz}, 3 \mathrm{H}) ;{ }^{13} \mathrm{C} \mathrm{NMR}\left(\mathrm{CDCl}_{3} / 125 \mathrm{MHz}\right) \delta 173.9,171.0,155.2,137.8,129.5,128.7$, 127.0, 79.7, 78.3, 69.9, 60.2, 52.4, 46.9, 35.1, 28.5, 22.8, 19.9, 10.6; IR (neat/NaCl) 3429, 3347, 3108, 3087, 3063, 3029, 2977, 2877, 1954, 1755-1644, 1605, 1585, 1538-1434, 1367, 1247, 1162, 1089, 1024, 982, 908, 872, 855, 752, $702 \mathrm{~cm}^{-1}$; LRFAB MS (relative intensity) m/z 429 (18) $\mathrm{MLi}^{+}, 373$ (12), 329 (14), 136 (16), 89 (100); HRFAB MS m/z calculated for $[\mathrm{M}+\mathrm{Li}]^{+} 429.2577$, found 429.2561 and 430.2594 $\left({ }^{13} \mathrm{C}\right)$.

2-[N-(2-tert-Butoxycarbonylaminopropionyl)-N-(n-butoxy)methylamino]-3-phenylpropionic acid methyl ester (made from 44b):

The butoxy ether from 44b was prepared using the general procedure described above. The substrate (44b) (0.094 g, $0.21 \mathrm{mmol})$, tetrabutylammonium tetrafluoroborate $(0.710 \mathrm{~g}, 2.14 \mathrm{mmol})$, and anhydrous n-butanol $(21 \mathrm{~mL})$ were combined to make the electrolysis reaction solution. The crude product was chromatographed as described above to afford $0.060 \mathrm{~g}(64 \%)$ of $>98 \%$ pure product. ${ }^{1} \mathrm{H}$ NMR $\left(\mathrm{CDCl}_{3} / 500 \mathrm{MHz}\right) . \delta 7.28-7.16(\mathrm{~m}, 5 \mathrm{H}), 5.33(\mathrm{br} \mathrm{d}, \mathrm{J}=7.5 \mathrm{~Hz}, 1 \mathrm{H}), 4.61$ (quartet of doublets, app quintet, $\mathrm{J} \approx 7 \mathrm{~Hz}, 1 \mathrm{H}), 4.49\left(\mathrm{~A}\right.$ of $\left.\mathrm{AB}, \mathrm{J}_{\mathrm{AB}}=11.0 \mathrm{~Hz}, 1 \mathrm{H}\right)$, ca $4.47(\mathrm{dd}, \mathrm{J}=6.0,10.0 \mathrm{~Hz}, 1 \mathrm{H}), 4.26\left(\mathrm{~B}\right.$ of $\mathrm{AB}, \mathrm{J}_{\mathrm{AB}}=11.5$ $\mathrm{Hz}, 1 \mathrm{H}), 3.71(\mathrm{~s}, 3 \mathrm{H}), 3.47$ (triplet of doublets, app quartet, $\mathrm{J} \approx 7 \mathrm{~Hz}, 1 \mathrm{H}), 3.38\left(\mathrm{~A}\right.$ of $\mathrm{ABX}, \mathrm{J}_{\mathrm{AB}}=14.0 \mathrm{~Hz}$, $\left.\mathrm{J}_{\mathrm{AX}}=5.5 \mathrm{~Hz}, 1 \mathrm{H}\right)$, ca 3.26 (app quartet buried under $\mathrm{B}$ of $\left.\mathrm{ABX}, 1 \mathrm{H}\right), 3.22\left(\mathrm{~B}\right.$ of $\mathrm{ABX}, \mathrm{J}_{\mathrm{AB}}=14.0 \mathrm{~Hz}$, $\mathrm{J}_{\mathrm{BX}}=10.5 \mathrm{~Hz}, 1 \mathrm{H}$ ), ca 1.45 (methylene buried under s), $1.43(\mathrm{~s}, 9 \mathrm{H}), 1.31$ (app sextet, $\left.\mathrm{J}=7.5 \mathrm{~Hz}, 2 \mathrm{H}\right), 1.26$ $(\mathrm{d}, \mathrm{J}=7.0 \mathrm{~Hz}, 3 \mathrm{H}), 0.89$ (t, J=7.5 Hz, 3H); ${ }^{13} \mathrm{C} \mathrm{NMR}\left(\mathrm{CDCl}_{3} / 125 \mathrm{MHz}\right) .173 .9,171.0,155.2,137.9,129.5$, 128.7, 127.0, 79.7, 78.3, 68.2, 60.3, 52.4, 46.9, 35.1, 31.7, 28.5, 20.0, 19.4, 14.0; IR (neat/NaCl) 3427, $3345,3086,3063,3028,2959,2933,2872,1953,1745-1660,1605,1585,1496,1454,1391,1366,1247$, 1166, 1092, 1025, 983, 935, 908, 856, 753, $702 \mathrm{~cm}^{-1}$; LRFAB MS (relative intensity) m/z 443 (3) $\mathrm{MLi}^{+}$, 313 (17), 160 (100), 136 (13), 89 (14); HRFAB MS m/z calculated for $[\mathrm{M}+\mathrm{Li}]^{+} 443.2733$, found 443.2720 and $444.2753\left({ }^{13} \mathrm{C}\right)$.

2-[(N-(2-tert-Butoxycarbonylamino-3-phenylpropionyl)-N-methoxymethylamino]-3phenylpropionic acid methyl ester (made from 44c): 
The methoxy ether from 44c was prepared using the general procedure described above. The substrate $(\mathbf{4 4 c})(0.096 \mathrm{~g}, 0.19 \mathrm{mmol})$, tetrabutylammonium tetrafluoroborate $(0.617 \mathrm{~g}, 1.87 \mathrm{mmol})$, and anhydrous methanol $(18 \mathrm{~mL})$ were combined to make the electrolysis reaction solution. The crude product was chromatographed as described above to afford $0.067 \mathrm{~g}(76 \%)$ of pure product. ${ }^{1} \mathrm{H}$ NMR $\left(\mathrm{CDCl}_{3} / 300 \mathrm{MHz}\right) \delta$ 7.32-7.15 (m, 8H), 7.05-7.03 (m, 2H), $5.10(\mathrm{~d}, \mathrm{~J}=9.3 \mathrm{~Hz}, 1 \mathrm{H}), 4.81$ (ddd, app quartet, $\mathrm{J} \approx 7 \mathrm{~Hz}, 1 \mathrm{H}), 4.52(\mathrm{dd}, \mathrm{J}=8.7,6.0 \mathrm{~Hz}, 1 \mathrm{H}), 4.42(\mathrm{~d}, \mathrm{~J}=10.8 \mathrm{~Hz}, 1 \mathrm{H}), 4.30(\mathrm{~d}, \mathrm{~J}=11.4 \mathrm{~Hz} 1 \mathrm{H}), 3.70(\mathrm{~s}, 3 \mathrm{H})$, $3.38(\mathrm{dd}, \mathrm{J}=14.2,6.2 \mathrm{~Hz}, 1 \mathrm{H}), 3.13(\mathrm{~s}, 3 \mathrm{H}), 3.16-3.01(\mathrm{~m}, 2 \mathrm{H}), 2.86$ (dd, J=13.5, 7.2 Hz, 1H), 1.37 (s, $9 \mathrm{H}) ;{ }^{13} \mathrm{C} \mathrm{NMR}\left(\mathrm{CDCl}_{3} / 75 \mathrm{MHz}\right) \delta 172.7,170.9,155.1,137.8,136.7,129.7,129.4,128.7,127.0,126.8$, 80.0, 79.2, 60.2, 55.6, 52.5, 52.2, 39.9, 35.4, 28.4; IR (neat/NaCl) 3327, 2975, 2924, 1743, 1698, 1659 , 1454, 1250, 1169, 1082, 912, 752, 733, $699 \mathrm{~cm}^{-1}$; LRFAB MS (relative intensity) m/z 477 (100) $\mathrm{MLi}^{+}$, 377 (34) $\mathrm{MLi}^{+}-\mathrm{Boc}+\mathrm{H}, 198$ (22), 89 (72); HRMS m/z calculated for [M+Li] ${ }^{+}$477.2577, found 477.2588 and $478.2613\left({ }^{13} \mathrm{C}\right)$.

\section{2-[N-(2-tert-Butoxycarbonylamino-3-phenylpropionyl)-N-ethoxymethylamino]-3-phenylpropionic acid methyl ester (made from $44 \mathrm{c}$ ):}

The ethoxy ether from $\mathbf{4 4 c}$ was prepared using the general procedure described above. The substrate $(\mathbf{4 4 c})(0.094 \mathrm{~g}, 0.18 \mathrm{mmol})$, tetrabutylammonium tetrafluoroborate $(0.601 \mathrm{~g}, 1.83 \mathrm{mmol})$, and anhydrous ethanol $(18 \mathrm{~mL})$ were combined to make the electrolysis reaction solution. The crude product was chromatographed as described above to afford $0.052 \mathrm{~g}(59 \%)$ of pure product. ${ }^{1} \mathrm{H} \mathrm{NMR}\left(\mathrm{CDCl}_{3} / 500\right.$ $\mathrm{MHz}$ ). $\delta 7.29-7.05(\mathrm{~m}, 10 \mathrm{H}), 5.11$ (br d, J=9.5 Hz, 1H), 4.83 (ddd, app quartet, J $\approx 7 \mathrm{~Hz}, 1 \mathrm{H}$ ), 4.56 (dd, $\mathrm{J}=6.0,8.5 \mathrm{~Hz}, 1 \mathrm{H}), 4.46\left(\mathrm{~A}\right.$ of $\left.\mathrm{AB}, \mathrm{J}_{\mathrm{AB}}=11.5 \mathrm{~Hz}, 1 \mathrm{H}\right), 4.40\left(\mathrm{~B}\right.$ of $\left.\mathrm{AB}, \mathrm{J}_{\mathrm{AB}}=11.5 \mathrm{~Hz}, 1 \mathrm{H}\right), 3.68(\mathrm{~s}, 3 \mathrm{H})$, 3.41-3.35 (m, 2H), 3.23 (quartet of doublets, app quintet, $\mathrm{J} \approx 7 \mathrm{~Hz}, 1 \mathrm{H}$ ), 3.07-3.02 (m, 2H), 2.87 (dd, J=7.0, $14.0 \mathrm{~Hz}, 1 \mathrm{H}), 1.37(\mathrm{~s}, 9 \mathrm{H}), 1.07(\mathrm{t}, \mathrm{J}=7.0 \mathrm{~Hz}, 3 \mathrm{H}) ;{ }^{13} \mathrm{C} \mathrm{NMR}\left(\mathrm{CDCl}_{3} / 125 \mathrm{MHz}\right) \delta 172.7,170.9,155.1$, $137.9,136.8,129.7,129.4,128.6,127.0,126.8,79.9,77.7,63.6,60.1,52.4,52.1,40.0,35.4,28.4,15.0$; IR (neat/NaCl) 3426, 3331, 3167, 3108, 3087, 3063, 3029, 2978, 2872, 1951, 1887, 1807, 1754-1634, $1605,1585,1538-1361,1167,1097,1018,982,924,906,856,823,801,751,699 \mathrm{~cm}^{-1}$; LRFAB MS (relative intensity) m/z 491 (100) $\mathrm{MLi}^{+}, 435$ (35), 391 (30), 299 (12), 242 (15), 198 (58), 160 (49), 120 (53), 91 (30); HRFAB MS m/z calculated for $[\mathrm{M}+\mathrm{Li}]^{+} 491.2733$, found 491.2720 and $492.2756\left({ }^{13} \mathrm{C}\right)$.

\section{2-[N-(2-tert-Butoxycarbonylamino-3-phenylpropionyl)-N-(n-propoxy)methylamino]-3- phenylpropionic acid methyl ester (made from 44c):}

The propoxy ether from $\mathbf{4 4 c}$ was prepared using the general procedure described above. The substrate (44c) $(0.093 \mathrm{~g}, 0.18 \mathrm{mmol})$, tetrabutylammonium tetrafluoroborate $(0.605 \mathrm{~g}, 1.84 \mathrm{mmol})$, and anhydrous n-propanol $(18 \mathrm{~mL})$ were combined to make the electrolysis reaction solution. The crude product was chromatographed as described above to afford $0.050 \mathrm{~g}(55 \%)$ of $\sim 98 \%$ pure product. ${ }^{1} \mathrm{H}$ NMR $\left(\mathrm{CDCl}_{3} / 500 \mathrm{MHz}\right) . \delta 7.29-7.06(\mathrm{~m}, 10 \mathrm{H}), 5.11($ br d, J=9.5 Hz, 1H), 4.84 (ddd, app quartet, J $\approx 8$, $1 \mathrm{H}), 4.57(\mathrm{dd}, \mathrm{J}=6.0,8.0 \mathrm{~Hz}, 1 \mathrm{H}), 4.46\left(\mathrm{~A}\right.$ of $\left.\mathrm{AB}, \mathrm{J}_{\mathrm{AB}}=11.5 \mathrm{~Hz}, 1 \mathrm{H}\right), 4.41\left(\mathrm{~B}\right.$ of $\left.\mathrm{AB}, \mathrm{J}_{\mathrm{AB}}=11.5 \mathrm{~Hz}, 1 \mathrm{H}\right)$, $3.68(\mathrm{~s}, 3 \mathrm{H}), 3.38(\mathrm{dd}, \mathrm{J}=6.0,14.0 \mathrm{~Hz}, 1 \mathrm{H}), 3.30$ (triplet of doublets, app quartet, $\mathrm{J} \approx 7,1 \mathrm{H}$ ), 3.14 (triplet of doublets, app quartet, $\mathrm{J} \approx 7,1 \mathrm{H}), 3.07-3.02(\mathrm{~m}, 2 \mathrm{H}), 2.87(\mathrm{dd}, \mathrm{J}=6.5,13.0 \mathrm{~Hz}, 1 \mathrm{H}), 1.46$ (sextet, J=7.0 Hz, $2 \mathrm{H}), 1.37(\mathrm{~s}, 9 \mathrm{H}), 0.84(\mathrm{t}, \mathrm{J}=7.5 \mathrm{~Hz}, 3 \mathrm{H}) ;{ }^{13} \mathrm{C} \mathrm{NMR}\left(\mathrm{CDCl}_{3} / 125 \mathrm{MHz}\right) \delta 172.8,170.9,155.1,137.9$, $136.8,129.7,129.4,128.6,127.0,126.8,79.9,77.9,69.9,60.1,52.3,52.1,40.0,35.5,28.5,22.8,10.6$; IR (neat $/ \mathrm{NaCl}) 3426,3333,3168,3108,3087,3063,3029,3003,2978,2920,2877,2857,2252,1952,1880$, 1766-1633, 1605, 1585, 1556-1454, 925, 908, 858, $697 \mathrm{~cm}^{-1}$; HRFAB MS m/z calculated for [M+Li] ${ }^{+}$ 505.2890, found 505.2890 and 506.2917 $\left({ }^{13} \mathrm{C}\right)$.

\section{2-[N-(2-tert-Butoxycarbonylamino-3-phenylpropionyl)-N-(n-butoxy)methylamino]-3- phenylpropionic acid methyl ester (made from 44c):}

The butoxy product from $44 \mathbf{c}$ was prepared using the general procedure described above. The substrate $(44 \mathrm{c})(0.098 \mathrm{~g}, 0.19 \mathrm{mmol})$, tetrabutylammonium tetrafluoroborate $(0.626 \mathrm{~g}, 1.90 \mathrm{mmol})$, and anhydrous n-butanol $(18 \mathrm{~mL})$ were combined to make the electrolysis reaction solution. The crude 
product was chromatographed as described above to afford $0.030 \mathrm{~g}(31 \%)$ of $\sim 94 \%$ pure product. ${ }^{1} \mathrm{H}$ NMR $\left(\mathrm{CDCl}_{3} / 500 \mathrm{MHz}\right) \delta 7.29-7.06(\mathrm{~m}, 10 \mathrm{H}), 5.11$ (br d, J=9.0 Hz, 1H), 4.84 (ddd, app quartet, J $\approx 8 \mathrm{~Hz}$, $1 \mathrm{H}), 4.56(\mathrm{dd}, \mathrm{J}=6.5,8.5 \mathrm{~Hz}, 1 \mathrm{H}), 4.45\left(\mathrm{~A}\right.$ of $\left.\mathrm{AB}, \mathrm{J}_{\mathrm{AB}}=11.0 \mathrm{~Hz}, 1 \mathrm{H}\right), 4.40\left(\mathrm{~B}\right.$ of $\left.\mathrm{AB}, \mathrm{J}_{\mathrm{AB}}=11.0 \mathrm{~Hz}, 1 \mathrm{H}\right)$, $3.68(\mathrm{~s}, 3 \mathrm{H}), 3.40-3.33(\mathrm{~m}, 2 \mathrm{H}), 3.18$ (triplet of doublets, app quartet, $\mathrm{J} \approx 7 \mathrm{~Hz}, 1 \mathrm{H}), 3.06-3.01(\mathrm{~m}, 2 \mathrm{H})$, $2.87(\mathrm{dd}, \mathrm{J}=7.0,13.5 \mathrm{~Hz}, 1 \mathrm{H}), 1.45-1.33$ (methylene buried under s), $1.37(\mathrm{~s}, 9 \mathrm{H}), 1.30-1.24(\mathrm{~m}, 2 \mathrm{H}), 0.87$ $(\mathrm{t}, \mathrm{J}=7.0 \mathrm{~Hz}, 3 \mathrm{H}) ;{ }^{13} \mathrm{C} \mathrm{NMR}\left(\mathrm{CDCl}_{3} / 125 \mathrm{MHz}\right) \delta 172.8,170.9,155.1,137.9,136.8,129.7,129.4,128.6$, 127.0, 126.8, 79.9, 78.0, 68.1, 60.1, 52.3, 52.1, 40.0, 35.5, 31.7, 28.4, 19.4, 14.0; IR (neat/NaCl) 3430, 3332 , 3107, 3087, 3063, 3029, 3003, 2958, 2932, 2872, 1950, 1888, 1807, 1746-1644, 1605, 1585, 1515, 1495, 1454, 1392, 1366, 1282, 1247, 1168, 1087, 1048, 1020, 983, 930, 908, 857, 824, 751, $700 \mathrm{~cm}^{-1}$; LRFAB MS (relative intensity) m/z 519 (100) $\mathrm{MLi}^{+}, 464$ (8), 420 (8), 314 (5), 160 (28); HRFAB MS m/z calculated for $[\mathrm{M}+\mathrm{Li}]^{+} 519.3046$, found 519.3043 and $520.3070\left({ }^{13} \mathrm{C}\right)$.

\section{HPLC Characterization of electrolysis products:}

Compounds 8-19 were characterized by reverse phase HPLC with toluene and/or benzene internal standards. Response factors (RF) were calculated from peak areas (Absorption Units x Time) and are indicated on the chromatograms shown below. The response factors indicated are the average value of at least three response factors calculated from chromatograms generated using different relative concentrations of substrates and internal standard. In addition, response factors have been corrected for starting material impurities in the analytes.

\section{Parallel electrolysis of silylated dipeptides 44a, 44b, and 44c:}

Substrates in amounts indicated in Table 1A (below) were added to twelve $20 \mathrm{~mL}$ vials (reaction cells). Next, $10 \mathrm{~mL}$ of $100 \mathrm{mM} \mathrm{Bu} \mathrm{NBF}_{4} /$ alcohol solution (anhydrous) was added to each vial as indicated in Table 1A. Onto each vial was placed a plastic cap, into which two carbon electrodes had been inserted (the anodes bearing $1 \mathrm{~cm} \times 1 \mathrm{~cm} \times 1 \mathrm{~cm}$ pieces of RVC on their tips). Each cell was connected to an independent potentiostat of the Arbin power supply, and electrolyses were performed simultaneously in each cell with stirring. All electrolyses were run with a constant current of $8 \mathrm{~mA}$, supplying 2.2 Faradays/mole of electrons with the exception of cell 8 . The resistance across cell 8 was great enough to exceed the voltage limit of the Arbin potentiostat. As result, approximately $6 \mathrm{~mA}$ was passed during the run time, supplying approximately 1.6 Faradays/mole of electrons to that cell. After the electrolyses were complete, all vials were capped until analysis was performed the following day ( $\sim 15 \mathrm{~h}$ later).

Table 1A

\begin{tabular}{|l|c|c|c|c|c|c|}
\hline Cell & $\begin{array}{c}\text { Starting } \\
\text { Material }\end{array}$ & $\begin{array}{c}\text { Mass } \\
\text { Used }\end{array}$ & $\mathbf{m M o l e s}$ & $\begin{array}{c}\text { Alcohol } \\
\text { Solvent }\end{array}$ & $\begin{array}{c}\text { Run } \\
\text { Time } \\
\text { (Min:Sec) }\end{array}$ & $\begin{array}{c}\text { F/mole } \\
\text { Passed }\end{array}$ \\
\hline 1 & $\mathbf{3 0 a}$ & $42 \mathrm{mg}$ & 0.099 & Methanol & $45: 00$ & 2.2 \\
\hline 2 & $\mathbf{3 0 a}$ & $42 \mathrm{mg}$ & 0.099 & Ethanol & $45: 00$ & 2.2 \\
\hline 3 & $\mathbf{3 0 a}$ & $43 \mathrm{mg}$ & 0.10 & n-Propanol & $45: 00$ & 2.2 \\
\hline 4 & $\mathbf{3 0 a}$ & $43 \mathrm{mg}$ & 0.10 & n-Butanol & $45: 00$ & 2.2 \\
\hline 5 & $\mathbf{4 4 b}$ & $44 \mathrm{mg}$ & 0.10 & Methanol & $44: 52$ & 2.2 \\
\hline 6 & $\mathbf{4 4 b}$ & $44 \mathrm{mg}$ & 0.10 & Ethanol & $44: 52$ & 2.2 \\
\hline 7 & $\mathbf{4 4 b}$ & $44 \mathrm{mg}$ & 0.10 & n-Propanol & $44: 52$ & 2.2 \\
\hline 8 & $\mathbf{4 4 b}$ & $44 \mathrm{mg}$ & 0.10 & n-Butanol & $44: 52$ & $\sim 1.6$ \\
\hline 9 & $\mathbf{4 4 c}$ & $51 \mathrm{mg}$ & 0.099 & Methanol & $43: 44$ & 2.2 \\
\hline 10 & $\mathbf{4 4 c}$ & $51 \mathrm{mg}$ & 0.099 & Ethanol & $43: 44$ & 2.2 \\
\hline 11 & $\mathbf{4 4 c}$ & $50 \mathrm{mg}$ & 0.098 & n-Propanol & $43: 44$ & 2.2 \\
\hline 12 & $\mathbf{4 4 c}$ & $50 \mathrm{mg}$ & 0.098 & n-Butanol & $43: 44$ & 2.2 \\
\hline
\end{tabular}

HPLC analysis was performed by co-dissolving measured amounts crude electrolysis solutions with internal standard solutions (made in IPA) and injecting those mixtures directly into the HPLC 
column. Elution conditions and response factors used for each assay were those established by earlier HPLC characterizations. Yields of the parallel syntheses are listed in Table 1 of the text. Adequate resolution between the butoxy ether products and their unreacted silylated starting materials was not achieved by HPLC. Therefore, those products were isolated by silica gel chromatography. Percent yields listed for the butoxy ether products have been corrected for any residual starting material observed in their NMR spectra. In addition, the product from experiment 5 was isolated by silica gel chromatography so that its percent yield of isolated product could be compared to its percent yield by HPLC analysis.

\section{2-[N-(2-Benzyloxycarbonylaminoacetyl)-N-trimethylsilanylmethylamino]-3-phenylpropionic acid methyl ester (45a):}

Compound 45a was prepared using the general procedure outlined above. Dichloromethane (60 $\mathrm{mL})$, NMM (1.0 mL, $9.1 \mathrm{mmol})$, and isobutylchloroformate $(0.58 \mathrm{~mL}, 4.5 \mathrm{mmol})$ were initially combined. N-(Carbobenzyloxy)-glycine $(0.948 \mathrm{~g}, 4.53 \mathrm{mmol})$ and the N-trimethylsilylmethyl-Lphenylalanine methyl ester derivative $(27)(0.822 \mathrm{~g}, 3.08 \mathrm{mmol})$ were then added. The crude product was chromatographed as described above to afford $1.176 \mathrm{~g} \mathrm{(84 \% )}$ of pure product, which was a very viscous, colorless liquid. ${ }^{1} \mathrm{H}$ NMR $\left(\mathrm{CDCl}_{3} / 300 \mathrm{MHz}\right.$ ) (Two main rotamers with approximately 1:1 ratio were observed.) $\delta$ 7.34-7.09 (m, 10H), 5.81 and 5.62 (br s and br s, 1H), 5.10 and 5.03 (s and s, 2H), 4.40 (dd, $\mathrm{J}=9.4,5.2 \mathrm{~Hz}, 0.5 \mathrm{H}), 3.99-3.76(\mathrm{~m}, 2 \mathrm{H}), 3.70$ and $3.69(\mathrm{~s}$ and $\mathrm{s}, 3 \mathrm{H}), 3.34-3.20(\mathrm{~m}, 2 \mathrm{H}), 2.99(\mathrm{dd}, \mathrm{J}=14.2$, $9.4 \mathrm{~Hz}, 0.5 \mathrm{H}), 2.72\left(\mathrm{~A}\right.$ of $\left.\mathrm{AB}, \mathrm{J}_{\mathrm{AB}}=14.7 \mathrm{~Hz}, 0.5 \mathrm{H}\right), 2.57\left(\mathrm{~A}\right.$ of $\left.\mathrm{AB}, \mathrm{J}_{\mathrm{AB}}=16.5 \mathrm{~Hz}, 0.5 \mathrm{H}\right), 2.50$ (B of AB, $\left.\mathrm{J}_{\mathrm{AB}}=14.4 \mathrm{~Hz}, 0.5 \mathrm{H}\right), 1.77\left(\mathrm{~B}\right.$ of $\left.\mathrm{AB}, \mathrm{J}_{\mathrm{AB}}=16.5 \mathrm{~Hz}, 0.5 \mathrm{H}\right), 0.02$ and $0.01(\mathrm{~s}$ and $\mathrm{s}, 9 \mathrm{H}) ;{ }^{13} \mathrm{C} \mathrm{NMR}\left(\mathrm{CDCl}_{3} / 75\right.$ MHz) $\delta 170.2,170.0,167.8,167.1,156.2,155.9,137.8,136.6,136.5,136.2,129.2,129.0,129.0,128.8$, $128.5,128.5,128.1,128.0,127.4,126.9,66.8,66.7,64.6,61.3,52.6,52.3,43.1,42.2,40.8,36.0,35.4$, 34.4; IR (neat/ $\mathrm{NaCl}) 3410,3064,3030,2952,1738,1699,1660,1505,1435,1351,1248,1049,851,753$, $699 \mathrm{~cm}^{-1}$; LR MS (relative intensity) m/z 457 (100) $\mathrm{MH}^{+}, 441$ (72), 266 (84), 206 (79), 121 (56); HR MS $\mathrm{m} / \mathrm{z}$ calculated for $[\mathrm{M}+\mathrm{H}]^{+} 457.2159$, found 457.2138 , and $458.2176\left({ }^{13} \mathrm{C}\right)$.

\section{2-[N-(2-Benzyloxycarbonylaminopropionyl)-N-trimethylsilanylmethylamino]-3-phenylpropionic acid methyl ester (45b):}

Compound 45b was prepared using the general procedure outlined above. Dichloromethane (60 $\mathrm{mL})$, NMM $(0.99 \mathrm{~mL}, 9.0 \mathrm{mmol})$, and isobutylchloroformate $(0.59 \mathrm{~mL}, 4.5 \mathrm{mmol})$ were initially combined. N-(Carbobenzyloxy)-L-alanine $(1.001 \mathrm{~g}, 4.480 \mathrm{mmol})$ and the N-trimethylsilylmethyl-Lphenylalanine methyl ester derivative $(27)(0.800 \mathrm{~g}, 3.00 \mathrm{mmol})$ were then added. The crude product was chromatographed as described above to afford $0.738 \mathrm{~g} \mathrm{(52 \% )}$ of pure product, which was a very viscous, colorless liquid. ${ }^{1} \mathrm{H}$ NMR $\left(\mathrm{CDCl}_{3} / 500 \mathrm{MHz}\right)$ (Two rotamers with an approximate ratio of 4:3 were observed) $\delta 7.37-7.16(\mathrm{~m}, 10 \mathrm{H}), 5.78(\mathrm{br} \mathrm{d}, \mathrm{J}=7.5 \mathrm{~Hz}, 1 \mathrm{H}$ of major rotamer), $5.41(\mathrm{~d}, \mathrm{~J}=8.0 \mathrm{~Hz}, 1 \mathrm{H}$ of minor rotamer), 5.10 (s, $2 \mathrm{H}$ of major rotamer), 5.08 (s, $2 \mathrm{H}$ of minor rotamer), 4.85 (dd, J=6.0, $9.0 \mathrm{~Hz}, 1 \mathrm{H}$ of one rotamer), 4.45 (quartet of doublets, app quintet, $\mathrm{J} \approx 7 \mathrm{~Hz}, 1 \mathrm{H}$ of both rotamers), 3.75 (s, $3 \mathrm{H}$ of major rotamer), ca 3.75 ( $1 \mathrm{H}$ of one rotamer buried under s), $3.68(\mathrm{~s}, 3 \mathrm{H}$ of minor rotamer), 3.37 (A of $\mathrm{ABX}$, $\mathrm{J}_{\mathrm{AB}}=14.0 \mathrm{~Hz}, \mathrm{~J}_{\mathrm{AX}}=4.5 \mathrm{~Hz}, 1 \mathrm{H}$ of one rotamer), 3.35 (dd buried under $\mathrm{A}$ of $\mathrm{ABX}, 1 \mathrm{H}$ of one rotamer), 2.28 (B of $\mathrm{ABX}, \mathrm{J}_{\mathrm{AB}}=13.5 \mathrm{~Hz}, \mathrm{~J}_{\mathrm{BX}}=11.0 \mathrm{~Hz}, 1 \mathrm{H}$ of one rotamer), 3.01 (dd, $\mathrm{J}=8.5 \mathrm{~Hz}, 14.0 \mathrm{~Hz}, 1 \mathrm{H}$ of one rotomer), 2.71 ( $\mathrm{A}$ of $\mathrm{AB}, \mathrm{J}_{\mathrm{AB}}=16.5 \mathrm{~Hz}, 1 \mathrm{H}$ of major rotamer), 2.70 ( $\mathrm{A}$ of $\mathrm{AB}, \mathrm{J}_{\mathrm{AB}}=14.0 \mathrm{~Hz}, 1 \mathrm{H}$ of minor rotamer) $2.59\left(\mathrm{~B}\right.$ of $\mathrm{AB}, \mathrm{J}_{\mathrm{AB}}=14.5 \mathrm{~Hz}, 1 \mathrm{H}$ of minor rotamer), $1.87\left(\mathrm{~B}\right.$ of $\mathrm{AB}, \mathrm{J}_{\mathrm{AB}}=17.0 \mathrm{~Hz}, 1 \mathrm{H}$ of major rotamer), $1.30(\mathrm{~d}, \mathrm{~J}=6.5 \mathrm{~Hz}, 3 \mathrm{H}$ of major rotamer), $0.84(\mathrm{~d}, \mathrm{~J}=7.0 \mathrm{~Hz}, 3 \mathrm{H}$ of minor rotamer); 0.07 (s, $9 \mathrm{H}$ of major rotamer), $0.06\left(\mathrm{~s}, 9 \mathrm{H}\right.$ of minor rotamer); ${ }^{13} \mathrm{C} \mathrm{NMR}\left(\mathrm{CDCl}_{3} / 125 \mathrm{MHz}\right) \delta 172.6,171.3,170.3$, $170.2,155.5,155.3,138.0,136.7,136.6,129.5,129.3,129.0,128.7,128.6,128.1,128.0,127.4,127.0$, $66.8,66.7,64.9,62.3,52.5,52.2,47.3,46.1,42.4,36.4,35.9,34.7,19.2,18.6,-0.5,-2.1 ;$ IR (neat/NaCl) $3417,3306,3108,3088,3064,3031,2952,2898,2846,2251,1951,1874,1807,1754-1695$, 1658-1606, 1586, 1537-1434, 1375, 1346, 1065, 970, 911, 849, 771, 749, 699, 645, $622 \mathrm{~cm}^{-1}$; LREI MS (relative intensity) m/z 470 (9) $\mathrm{M}^{+}, 455$ (53), 379 (5), 347 (7), 292 (9), 206 (10), 160 (19), 130 (27), 91 (100); HREI MS m/z calculated for $\mathrm{M}^{+} 470.2237$, found 470.2248 and $271.2243\left({ }^{13} \mathrm{C}\right)$. 


\section{2-[N-(2-Benzyloxycarbonylamino-3-phenylpropionyl)-N-trimethylsilanylmethylamino]-3-}

phenylpropionic acid methyl ester (45c):

Compound 45c was prepared using the general procedure outlined above. Dichloromethane (50 $\mathrm{mL})$, NMM (1.11 mL, $10.1 \mathrm{mmol})$, and isobutylchloroformate $(0.66 \mathrm{~mL}, 5.1 \mathrm{mmol})$ were initially combined. N-(Carbobenzyloxy)-L-phenylalanine $(1.520 \mathrm{~g}, 5.08 \mathrm{mmol})$ and the N-trimethylsilylmethyl-Lphenylalanine methyl ester derivative (27) $(0.900 \mathrm{~g}, 3.37 \mathrm{mmol})$ were then added. The crude product was chromatographed as described above to afford $0.876 \mathrm{~g}(48 \%)$ of pure product, which was a very viscous, colorless liquid. ${ }^{1} \mathrm{H}$ NMR $\left(\mathrm{CDCl}_{3} / 300 \mathrm{MHz}\right)$ (Two main rotamers with approximately 1:1 ratio were observed.) $\delta$ 7.60-7.00 (m, 15H), $5.63(\mathrm{~d}, \mathrm{~J}=9.0 \mathrm{~Hz}, 0.5 \mathrm{H}), 5.37(\mathrm{~d}, \mathrm{~J}=7.8 \mathrm{~Hz}, 0.5 \mathrm{H}), 5.16-4.95(\mathrm{~m}, 2.5 \mathrm{H})$, 4.83 (ddd, app quartet, $\mathrm{J} \approx 7 \mathrm{~Hz}, 0.5 \mathrm{H}), 4.66(\mathrm{td}, \mathrm{J}=9.6,5.1 \mathrm{~Hz}, 0.5 \mathrm{H}), 3.93(\mathrm{dd}, \mathrm{J}=8.7,5.4 \mathrm{~Hz}, 0.5 \mathrm{H}), 3.79$ and 3.70 (s and s, $3 \mathrm{H}), 3.52(\mathrm{dd}, \mathrm{J}=14.2,5.6 \mathrm{~Hz}, 0.5 \mathrm{H}), 3.39(\mathrm{dd}, \mathrm{J}=14.0,5.2 \mathrm{~Hz}, 0.5 \mathrm{H}), 3.14(\mathrm{dd}, \mathrm{J}=13.8$, $9.3 \mathrm{~Hz}, 0.5 \mathrm{H}), 3.09(\mathrm{t}, \mathrm{J}=6.8 \mathrm{~Hz}, 0.5 \mathrm{H}), 3.01-2.93(\mathrm{~m}, 1 \mathrm{H}), 2.85\left(\mathrm{~A}\right.$ of $\left.\mathrm{AB}, \mathrm{J}_{\mathrm{AB}}=16.2 \mathrm{~Hz}, 0.5 \mathrm{H}\right), 2.84(\mathrm{~A}$ of $\left.\mathrm{AB}, \mathrm{J}_{\mathrm{AB}}=14.4 \mathrm{~Hz}, 0.5 \mathrm{H}\right), 2.75(\mathrm{dd}, \mathrm{J}=14.4,9.6 \mathrm{~Hz}, 0.5 \mathrm{H}), 2.64\left(\mathrm{~B}\right.$ of $\left.\mathrm{AB}, \mathrm{J}_{\mathrm{AB}}=14.1 \mathrm{~Hz}, 0.5 \mathrm{H}\right), 2.33$ (dd, $\mathrm{J}=14.2,5.0 \mathrm{~Hz}, 0.5 \mathrm{H}), 2.03\left(\mathrm{~B}\right.$ of $\left.\mathrm{AB}, \mathrm{J}_{\mathrm{AB}}=16.5 \mathrm{~Hz}, 0.5 \mathrm{H}\right), 0.15$ and 0.13 (s and $\mathrm{s}, 9 \mathrm{H}$ ); ${ }^{13} \mathrm{C}$ NMR $\left(\mathrm{CDCl}_{3} / 75 \mathrm{MHz}\right) \delta 171.7,170.4,170.3,170.3,155.6,155.4,138.2,136.7,136.6,136.6,136.3,135.0$, $130.3,129.7,129.4,129.4,129.1,129.0,128.7,128.6,128.6,128.4,128.3,128.1,128.1,128.0,127.9$, $127.8,127.6,127.4,127.1,126.9,126.7,126.5,69.0,67.1,66.9,64.5,62.4,52.5,52.2,51.0,41.6,40.1$, 38.4, 36.6, 35.8, 34.9, -0.4, -2.0; IR (neat/NaCl) 3302, 3030, 2951, 1732, 1634, 1455, 1248, 1029, 851, 736, $699 \mathrm{~cm}^{-1}$; LRFAB MS (relative intensity) m/z 553 (100) $\mathrm{MLi}^{+}, 91$ (100); HR MS m/z calculated for $[\mathrm{M}+\mathrm{Li}]^{+}$553.2710, found 553.2713.

Electrolysis of silylated dipeptides $45 \mathrm{a}, 45 \mathrm{~b}$, and $45 \mathrm{c}$ using reaction cells connected in series:

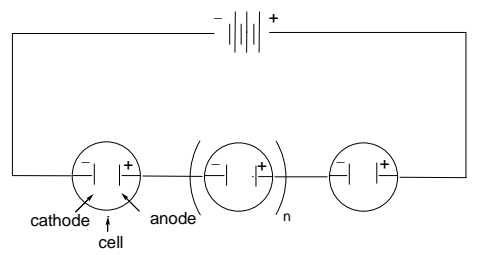

Substrates in amounts indicated in Table 2A were added to six $20 \mathrm{~mL}$ vials. Next, $15 \mathrm{~mL}$ of 100

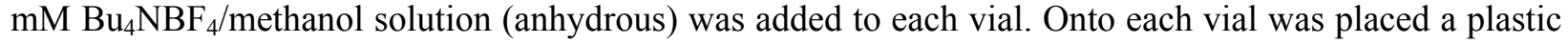
cap, into which two carbon electrodes had been inserted (the anodes bearing $1 \mathrm{~cm} \mathrm{x} 1 \mathrm{~cm} \mathrm{x} 1 \mathrm{~cm}$ pieces of RVC on their tips). A serial circuit was established by connecting the cells in a cathode-to-anode and anode-to-cathode fashion (see figure), with the cells at the ends connected to a single potentiostat of the Arbin power supply. The electrolysis was run with a constant current of $8 \mathrm{~mA}$ for $1 \mathrm{~h}$ and $19 \mathrm{~min}$, supplying 2.6 Faradays/mole of electrons to each reaction cell. At $8 \mathrm{~mA}$, the potential drop across the circuit was approximately $20 \mathrm{~V}$. After the electrolysis was complete, the vials were sealed until analysis was performed the next day $(\sim 15 \mathrm{~h})$.

Table 2A

\begin{tabular}{|c|c|c|c|c|c|c|c|}
\hline Cell & $\begin{array}{c}\text { Starting } \\
\text { Material }\end{array}$ & $\begin{array}{l}\text { Mass } \\
\text { Used }\end{array}$ & mMoles & Product & $\begin{array}{c}\text { Mass of Crude } \\
\text { Material } \\
\text { Recovered }\end{array}$ & $\begin{array}{c}\text { \% } \\
\text { Conversion } \\
\text { of Starting } \\
\text { Material }\end{array}$ & $\begin{array}{c}\text { \% Yield } \\
\text { of } \\
\text { Product }\end{array}$ \\
\hline 1 & $\mathbf{4 5 a}$ & $69 \mathrm{mg}$ & 0.15 & $\mathbf{4 6 a}$ & $60 \mathrm{mg}$ & 84 & 79 \\
\hline 2 & $\mathbf{4 5 a}$ & $69 \mathrm{mg}$ & 0.15 & $\mathbf{4 6 a}$ & $55 \mathrm{mg}$ & 85 & 74 \\
\hline 3 & $\mathbf{4 5 b}$ & $71 \mathrm{mg}$ & 0.15 & $\mathbf{4 6 b}$ & $58 \mathrm{mg}$ & $>99$ & 90 \\
\hline 4 & $\mathbf{4 5 b}$ & $71 \mathrm{mg}$ & 0.15 & $\mathbf{4 6 b}$ & $60 \mathrm{mg}$ & 83 & 77 \\
\hline 5 & $\mathbf{4 5 c}$ & $82 \mathrm{mg}$ & 0.15 & $\mathbf{4 6 c}$ & $70 \mathrm{mg}$ & $>99$ & 91 \\
\hline 6 & $\mathbf{4 5 c}$ & $82 \mathrm{mg}$ & 0.15 & $\mathbf{4 6 c}$ & $68 \mathrm{mg}$ & 92 & 82 \\
\hline
\end{tabular}


Samples were prepared for analysis by first removing methanol in vacuo. Then electrolyte was removed by filtration through silica gel with thorough washing of the gel with diethyl ether in order to capture the reaction products. Next, the ethereal filtrates were concentrated, the residues were weighed (see Table 2A), and proton NMR spectra of those samples were obtained. NMR spectra indicated the presence of only desired products and starting materials in the crude reaction mixtures. Percent conversions of starting materials to products were calculated from the molar ratios of starting materials to products observed in the proton NMR spectra of the crude reaction mixtures. Percent yields were calculated from the masses of crude materials recovered and the ratios of starting materials to products in those crude materials (see Table 2A). The crude mixtures from cells containing the same products were combined and chromarographed using the same stepwise elution described above for preparative electrolysis products. These materials were then fully characterized (see below) and used for the subsequent experiments described below.

2-[N-(2-Benzyloxycarbonylaminoacetyl)-N-methoxymethylamino]-3-phenylpropionic acid methyl ester (46a):

${ }^{1} \mathrm{H} \mathrm{NMR}\left(\mathrm{CDCl}_{3} / 300 \mathrm{MHz}\right) \delta$ 7.37-7.14 (m, 10H), 5.68 (br s, 1H), 5.12 (s, 2H), 4.54 (dd, J=9.9, $5.4 \mathrm{~Hz}, 1 \mathrm{H}), 4.45(\mathrm{~d}, \mathrm{~J}=11.1 \mathrm{~Hz}, 1 \mathrm{H}), 4.68(\mathrm{~d}, \mathrm{~J}=4.8 \mathrm{~Hz}, 2 \mathrm{H}), 4.01(\mathrm{~d}, \mathrm{~J}=11.1 \mathrm{~Hz}, 1 \mathrm{H}), 3.72(\mathrm{~s}, 3 \mathrm{H}), 3.36$ $(\mathrm{dd}, \mathrm{J}=14.2,5.6 \mathrm{~Hz}, 1 \mathrm{H}), 3.28-3.17(\mathrm{~m}, 1 \mathrm{H}), 3.22(\mathrm{~s}, 3 \mathrm{H}) ;{ }^{13} \mathrm{C} \mathrm{NMR}\left(\mathrm{CDCl}_{3} / 75 \mathrm{MHz}\right) \delta 170.7,169.4$, 156.3, 137.6, 136.6, 129.2, 128.8, 128.7, 128.3, 128.2, 127.0, 79.2, 67.1, 61.0, 55.9, 52.6, 42.8, 35.2; IR (neat/ $\mathrm{NaCl}) 3345,2951,1738,1673,1454,1235,1046,754,700 \mathrm{~cm}^{-1}$; LRFAB MS (relative intensity) $\mathrm{m} / \mathrm{z} 421$ (100) $\mathrm{MLi}^{+}, 91$ (100); HR MS m/z calculated for [M+Li] $]^{+} 421.1951$, found 421.1958.

2-[N-(2-Benzyloxycarbonylaminopropionyl)-N-methoxymethylamino]-3-phenylpropionic acid methyl ester (46b):

${ }^{1} \mathrm{H}$ NMR $\left(\mathrm{CDCl}_{3} / 300 \mathrm{MHz}\right) \delta$ 7.36-7.14 (m, 10H), 5.63 (br d, J=7.8 Hz, 1H), 5.09 (s, 2H), 4.68 (quartet of doublets, app quintet, $\mathrm{J} \approx 7 \mathrm{~Hz}, 1 \mathrm{H}), 4.44\left(\mathrm{~A}\right.$ of $\left.\mathrm{AB}, \mathrm{J}_{\mathrm{AB}}=11.1 \mathrm{~Hz}, 1 \mathrm{H}\right), 4.42$ (methine buried under $\mathrm{A}$ of $\mathrm{AB}), 4.12\left(\mathrm{~B}\right.$ of $\left.\mathrm{AB}, \mathrm{J}_{\mathrm{AB}}=11.1 \mathrm{~Hz}, 1 \mathrm{H}\right), 3.71(\mathrm{~s}, 3 \mathrm{H}), 3.39\left(\mathrm{~A}\right.$ of $\mathrm{ABX}, \mathrm{J}_{\mathrm{AB}}=14.1 \mathrm{~Hz}, \mathrm{~J}_{\mathrm{AX}}=5.6$ $\mathrm{Hz}, 1 \mathrm{H}), 3.25(\mathrm{~s}, 3 \mathrm{H}), 3.23\left(\mathrm{~B}\right.$ of $\left.\mathrm{ABX}, \mathrm{J}_{\mathrm{AB}}=14.1 \mathrm{~Hz}, \mathrm{~J}_{\mathrm{BX}}=10.2 \mathrm{~Hz}, 1 \mathrm{H}\right), 1.29(\mathrm{~d}, \mathrm{~J}=6.9 \mathrm{~Hz}, 3 \mathrm{H}) ;{ }^{13} \mathrm{C} \mathrm{NMR}$ $\left(\mathrm{CDCl}_{3} / 75 \mathrm{MHz}\right) \delta 173.3,170.8,155.6,137.7,136.5,129.4,128.7,128.7,128.3,128.1,127.0,79.6,66.9$, 60.4, 55.8, 52.5, 47.3, 35.0, 19.9; IR (neat/NaCl) 3316, 3108, 3087, 3063, 3030, 2983, 2950, 2841, 1958, 1887, 1743-1694, 1682-1651, 1605, 1586, 1538-1496, 1462-1434, 1393, 1354, 1239, 1096, 1057, 1028, 980, 913, 750, $700 \mathrm{~cm}^{-1}$; LRFAB MS (relative intensity) m/z 435 (100) $\mathrm{MLi}^{+}, 91$ (20); HRFAB MS m/z calculated for $[\mathrm{M}+\mathrm{Li}]^{+} 435.2107$, found 435.2116 and $436.2113\left({ }^{13} \mathrm{C}\right)$.

2-[N-(2-Benzyloxycarbonylamino-3-phenylpropionyl)-N-methoxymethylamino]-3-phenylpropionic acid methyl ester (46c):

${ }^{1} \mathrm{H} \mathrm{NMR}\left(\mathrm{CDCl}_{3} / 300 \mathrm{MHz}\right) \delta$ 7.37-7.05 (m, 15H), 5.38 (d, J=9.0 Hz, 1H), 5.04 (app. d, J=3.6 Hz, 2H), $4.89(\mathrm{dd}, \mathrm{J}=16.2,7.2 \mathrm{~Hz}, 1 \mathrm{H}), 4.58(\mathrm{dd}, \mathrm{J}=8.8,6.2 \mathrm{~Hz}, 1 \mathrm{H}), 4.40(\mathrm{~d}, \mathrm{~J}=11.4 \mathrm{~Hz}, 1 \mathrm{H}), 4.32(\mathrm{~d}, \mathrm{~J}=11.1$ $\mathrm{Hz}, 1 \mathrm{H}), 3.66(\mathrm{~s}, 3 \mathrm{H}), 3.37$ (dd, J=14.2, $6.2 \mathrm{~Hz}, 1 \mathrm{H}), 3.12(\mathrm{~s}, 3 \mathrm{H}), 3.08-2.98(\mathrm{~m}, 2 \mathrm{H}), 2.89$ (dd, J=13.4, 7.0 $\mathrm{Hz}, 1 \mathrm{H}) ;{ }^{13} \mathrm{C}$ NMR $\left(\mathrm{CDCl}_{3} / 75 \mathrm{MHz}\right) \delta 172.6,170.8,155.7,137.7,136.4,129.7,129.4,129.0,128.8$, $128.7,128.3,128.1,127.2,126.9,100.0,79.1,67.0,60.1,55.6,52.7,39.9,35.5 ;$ IR (neat/NaCl) 3309 , 3029, 1741, 1656, 1529, 1454, 1244, 1085, 1044, 750, $699 \mathrm{~cm}^{-1}$; LRFAB MS (relative intensity) m/z 511 (100) $\mathrm{MLi}^{+}, 313$ (14), 160 (69); HRMS m/z calculated for [M+Li] ${ }^{+}$511.2420, found 511.2413.

General procedure for the preparation of $\mathrm{N}$-phenylsulfanylmethyl substituted dipeptides (48a, 48b, and 48c) and N-ethylsulfanylmethyl substituted dipeptides $(47 \mathrm{a}, 47 \mathrm{~b}$, and $47 \mathrm{c})$ from $\mathrm{N}$ methoxymethyl substituted dipeptides (46a, 46b, and 46c):

A flame-dried, $2 \mathrm{~mL}$, screw-cap vial was charged with dipeptide starting material (1 equiv). Benzene was then added and removed in vacuo in order to remove residual water via a benzene/water azeotrope. Next, the vial was purged with argon and an injection port adaptor was screwed on in order to 
seal the vial. After that, dry dichloromethane, thiol (2 equiv), and $\mathrm{BF}_{3} \cdot \mathrm{OEt}_{2}(0.25$ or 0.5 equiv as indicated) were added in that order, and the reaction solution was stirred for $c a .18 \mathrm{~h}$. After completion, the reaction solution was concentrated and chromatographed through silica gel using the same stepwise elution described above for preparative electrolysis products. Amounts of reagents used and yields of products are indicated below. The purity of the products was determined by HPLC.

2-[N-(2-Benzyloxycarbonylaminoacetyl)-N-ethylsulfanylmethylamino]-3-phenylpropionic acid methyl ester (47a):

Compound 47a was prepared using the general procedure described above. Dry dichloromethane $(0.66 \mathrm{~mL})$, ethanethiol $(9.9 \mu \mathrm{L}, 0.13 \mathrm{mmol})$, and $\mathrm{BF}_{3} \cdot \mathrm{EtO}_{2}(2.1 \mu \mathrm{L}, 0.017 \mathrm{mmol})$ were added to $28 \mathrm{mg}$ $(0.067 \mathrm{mmol})$ of $\mathrm{N}$-methoxylmethylated dipeptide (46a). The crude product was chromatographed as described above to afford $24 \mathrm{mg}(79 \%)$ of product. The HPLC chromatogram of the purified material showed one major peak. ${ }^{1} \mathrm{H}$ NMR $\left(\mathrm{CDCl}_{3} / 300 \mathrm{MHz}\right.$ ) (Two rotamers with an approximate ratio of 5:1 were observed. Only the major rotamer is reported.). $\delta .37-7.14(\mathrm{~m}, 10 \mathrm{H}), 5.71(\mathrm{br} \mathrm{s}, 1 \mathrm{H}), 5.14(\mathrm{~s}, 2 \mathrm{H})$, $4.44(\mathrm{dd}, \mathrm{J}=5.1,10.5 \mathrm{~Hz}, 1 \mathrm{H}), 4.22\left(\mathrm{~A}\right.$ of $\left.\mathrm{AB}, \mathrm{J}_{\mathrm{AB}}=14.4 \mathrm{~Hz}, 1 \mathrm{H}\right), 4.05(\mathrm{~d}, \mathrm{~J}=4.5 \mathrm{~Hz}, 2 \mathrm{H}), 3.74(\mathrm{~s}, 3 \mathrm{H})$, ca $3.42\left(\mathrm{~A}\right.$ of $\left.\mathrm{ABX}, \mathrm{J}_{\mathrm{AB}}=13.8 \mathrm{~Hz}, \mathrm{~J}_{\mathrm{AX}}=5.1 \mathrm{~Hz}, 1 \mathrm{H}\right), 3.38\left(\mathrm{~B}\right.$ of $\left.\mathrm{AB}, \mathrm{J}_{\mathrm{AB}}=14.4,1 \mathrm{H}\right), 3.30\left(\mathrm{~B}\right.$ of $\mathrm{ABX}, \mathrm{J}_{\mathrm{AB}}=14.1$ $\left.\mathrm{Hz}, \mathrm{J}_{\mathrm{BX}}=10.5 \mathrm{~Hz}, 1 \mathrm{H}\right), 2.54-2.44(\mathrm{~m}, 2 \mathrm{H}), 1.19(\mathrm{t}, \mathrm{J}=7.5 \mathrm{~Hz}, 3 \mathrm{H}) ;{ }^{13} \mathrm{C} \mathrm{NMR}\left(\mathrm{CDCl}_{3} / 125 \mathrm{MHz}\right) \delta 170.4$, $168.2,156.3,137.7,136.6,129.3,129.0,128.7,128.3,128.2,127.1,67.1,61.1,52.7,50.3,43.1,34.6$, 24.7, 14.4; IR (neat/NaCl) 3407, 3340, 3087, 3063, 3030, 3003, 2951, 2930, 2871, 1957, 1882, 1738 1716, 1666-1652, 1604, 1585, 1537-1497, 1454, 1355, 1211, 1082, 1048, 1028, 987, 931, 910, 770, 752, $699 \mathrm{~cm}^{-1}$; LREI MS (relative intensity) m/z $444(<0.01) \mathrm{M}^{+}, 383$ (4) [M-SEt] $]^{+}, 339$ (6), 217 (8), 192 (75), 132 (53), 107 (19), 91 (100); LRFAB MS (relative intensity) m/z 451 (70) $\mathrm{MLi}^{+}, 91$ (100); HRFAB MS $\mathrm{m} / \mathrm{z}$ calculated for $[\mathrm{M}+\mathrm{Li}]^{+} 451.1879$, found 451.1861 and $452.1903\left({ }^{13} \mathrm{C}\right)$.

2-[N-(2-Benzyloxycarbonylaminopropionyl)-N-ethylsulfanylmethylamino]-3-phenylpropionic acid methyl ester (47b):

Compound 47b was prepared using the general procedure described above. Dry dichloromethane $(0.39 \mathrm{~mL})$, ethanethiol $(5.8 \mu \mathrm{L}, 0.078 \mathrm{mmol})$, and $\mathrm{BF}_{3} \cdot \mathrm{EtO}_{2}(1.8 \mu \mathrm{L}, 0.014 \mathrm{mmol})$ were added to $17 \mathrm{mg}$ $(0.039 \mathrm{mmol})$ of $\mathrm{N}$-methoxylmethylated dipeptide $(\mathbf{4 6 \mathbf { b }})$. The crude product was chromatographed as described above to afford $14 \mathrm{mg}(76 \%)$ of product. The HPLC chromatogram of the purified material showed one major peak. ${ }^{1} \mathrm{H} \mathrm{NMR}\left(\mathrm{CDCl}_{3} / 300 \mathrm{MHz}\right)$ (Two rotamers with an approximate ratio of 5:1 were observed. Only the major rotamer is reported.). $\delta$ 7.37-7.14 $(\mathrm{m}, 10 \mathrm{H}), 5.66(\mathrm{br} \mathrm{d}, \mathrm{J}=7.8 \mathrm{~Hz}, 1 \mathrm{H}), 5.09$ $(\mathrm{s}, 2 \mathrm{H}), 4.60(\mathrm{~m}, 1 \mathrm{H})$, ca $4.41(\mathrm{dd}, \mathrm{J}=4.8,10.8 \mathrm{~Hz}, 1 \mathrm{H})$, ca $4.36\left(\mathrm{~A}\right.$ of $\left.\mathrm{AB}, \mathrm{J}_{\mathrm{AB}}=14.7 \mathrm{~Hz}, 1 \mathrm{H}\right), 3.72(\mathrm{~s}, 3 \mathrm{H})$, 3.43 (A of $\left.A B X, J_{A B}=13.8 \mathrm{~Hz}, J_{A X}=4.5 \mathrm{~Hz}, 1 \mathrm{H}\right), 3.32\left(B\right.$ of $\left.A B, J_{A B}=14.7,1 H\right), 3.29\left(B\right.$ of $A B X, J_{A B}=14.1$ $\left.\mathrm{Hz}, \mathrm{J}_{\mathrm{BX}}=10.8 \mathrm{~Hz}, 1 \mathrm{H}\right), 2.53(\mathrm{q}, \mathrm{J}=7.5 \mathrm{~Hz}, 2 \mathrm{H}), 1.29(\mathrm{~d}, \mathrm{~J}=6.6 \mathrm{~Hz}, 3 \mathrm{H}), 1.20(\mathrm{t}, \mathrm{J}=7.3 \mathrm{~Hz}, 3 \mathrm{H}) ;{ }^{13} \mathrm{C} \mathrm{NMR}$ $\left(\mathrm{CDCl}_{3} / 125 \mathrm{MHz}\right) . \delta 172.3,170.5,155.6,137.8,136.6,129.5,128.9,128.7,128.3,128.2,127.2,67.0$, 60.5, 52.6, 51.2, 47.3, 34.7, 24.3, 19.8, 14.4; IR (neat/NaCl) 3318, 3106, 3087, 3063, 3030, 2952, 2928, 2872, 2852, 1955, 1879, 1801, 1748-1634, 1605, 1586, 1538-1418, 1375, 1353, 1255, 1061, 990, 936, 906, 847, 824, 738, $697 \mathrm{~cm}^{-1}$; LREI MS (relative intensity) m/z 397 (6) [M-SEt], 353 (6), 282 (8), 192 (22), 132 (13), 91 (100); LRFAB MS (relative intensity) m/z 465 (58) $\mathrm{MLi}^{+}, 313$ (22), 160 (100), 91 (84); HRFAB MS m/z calculated for $[\mathrm{M}+\mathrm{Li}]^{+} 465.2036$, found 465.2021 and $466.2060\left({ }^{13} \mathrm{C}\right)$.

\section{2-[N-(2-Benzyloxycarbonylamino-3-phenylpropionyl)-N-ethylsulfanylmethylamino]-3-phenyl- propionic acid methyl ester (47c):}

Compound 47c was prepared using the general procedure described above. Dry dichloromethane $(0.64 \mathrm{~mL})$, ethanethiol $(9.5 \mu \mathrm{L}, 0.13 \mathrm{mmol})$, and $\mathrm{BF}_{3} \cdot \mathrm{EtO}_{2}(2.0 \mu \mathrm{L}, 0.016 \mathrm{mmol})$ were added to $32 \mathrm{mg}$ $(0.064 \mathrm{mmol})$ of $\mathrm{N}$-methoxylmethylated dipeptide $(\mathbf{4 6 c})$. The crude product was chromatographed as described above to afford $27 \mathrm{mg}(78 \%)$ of product. The HPLC chromatogram of the purified material showed one major peak. ${ }^{1} \mathrm{H}$ NMR $\left(\mathrm{CDCl}_{3} / 300 \mathrm{MHz}\right)$ (Three rotamers with approximate ratios of 5:1:1 were observed. Only the major rotamer is reported.) $\delta$ 7.33-7.02 (m, 15H), $5.35(\mathrm{~d}, \mathrm{~J}=9.0 \mathrm{~Hz}, 1 \mathrm{H}), 5.04(\mathrm{~s}$, 
2H), 4.86 (ddd, app quartet, $J \approx 7 \mathrm{~Hz}, 1 \mathrm{H}), 4.51(\mathrm{dd}, \mathrm{J}=5.4,9.3 \mathrm{~Hz}, 1 \mathrm{H})$, ca $4.32\left(\mathrm{~A}\right.$ of $\mathrm{AB}, \mathrm{J}_{\mathrm{AB}}=14.4 \mathrm{~Hz}$, $1 \mathrm{H}), 3.68(\mathrm{~s}, 3 \mathrm{H})$, ca $3.66(\mathrm{~B}$ of $\mathrm{AB}$ buried under s, $1 \mathrm{H}), 3.44\left(\mathrm{~A}\right.$ of $\left.\mathrm{ABX}, \mathrm{J}_{\mathrm{AB}}=14.4 \mathrm{~Hz}, \mathrm{~J}_{\mathrm{AX}}=5.7 \mathrm{~Hz}, 1 \mathrm{H}\right)$, 3.12-3.02 (m, 2H), $2.89\left(B\right.$ of $\left.A B X, J_{A B}=13.5, \mathrm{~J}_{B X}=7.2 \mathrm{~Hz}, 1 \mathrm{H}\right), 2.39$ (doublet of quartets, $\mathrm{J}=2.1,7.2 \mathrm{~Hz}$, $2 \mathrm{H}), 1.14(\mathrm{t}, \mathrm{J}=7.5 \mathrm{~Hz}, 3 \mathrm{H}) ;{ }^{13} \mathrm{C} \mathrm{NMR}\left(\mathrm{CDCl}_{3} / 125 \mathrm{MHz}\right) \delta 171.5,170.6,155.7,137.9,136.5,129.7$, $129.4,128.8,128.8,128.7,128.3,128.0,127.2,126.9,67.0,60.4,52.6,52.5,50.7,39.9,35.1,24.5,14.5$; IR (neat/NaCl) 3304, 3108, 3086, 3062, 3029, 2951, 2927, 2870, 2854, 1953, 1880, 1806, 1739-1715, 1658-1635, 1604, 1585, 1530, 1496, 1454, 1231, 1151, 1083, 1028, 988, 909, 845, 824, 749, $699 \mathrm{~cm}^{-1}$; LREI MS (relative intensity) $\mathrm{m} / \mathrm{z} 534(<0.01) \mathrm{M}^{+}, 473(5)$ [M-SEt] ${ }^{+}, 365$ (5), 282 (9), 210 (6), 192 (17), 132 (15), 91 (100); LRFAB MS (relative intensity) m/z 540 (78) $\mathrm{MLi}^{+}, 313$ (14), 91 (74), 89 (100); HRFAB MS m/z calculated for $[\mathrm{M}+\mathrm{Li}]^{+} 541.2349$, found 541.2336 and $542.2374\left({ }^{13} \mathrm{C}\right)$.

\section{2-[N-(2-Benzyloxycarbonylaminoacetyl)-N-phenylsulfanylmethylamino]-3-phenylpropionic acid methyl ester (48a):}

Compound 48a was prepared using the general procedure described above. Four vials were charged with $16 \mathrm{mg}(0.038 \mathrm{mmol})$ each of $\mathrm{N}$-methoxylmethylated dipeptide (46a). To each vial, dichloromethane $(0.28 \mathrm{~mL})$ and benzenethiol $(8.0 \mu \mathrm{L}, 0.078 \mathrm{mmol})$ were added. Next, different volumes of $\mathrm{BF}_{3} \cdot \mathrm{OEt}_{2}$ were added to each vial as indicated: To vial $1,1.2 \mu \mathrm{L}(0.0094 \mathrm{mmol})$ was added; to vial 2 , $2.4 \mu \mathrm{L}(0.019 \mathrm{mmol})$ was added; to vial $3,3.5 \mu \mathrm{L}(0.028 \mathrm{mmol})$ was added, to vial $4,4.7 \mu \mathrm{L}(0.038$ $\mathrm{mmol}$ ) was added. The reactions were monitored by TLC, and after $20 \mathrm{~h}$ the starting material had been consumed in vials 2-4. Reaction solutions from vials 2-4 were combined and chromatographed as described above to afford $49 \mathrm{mg}(88 \%)$ of product. The HPLC chromatogram of the purified material showed one major peak. ${ }^{1} \mathrm{H}$ NMR $\left(\mathrm{CDCl}_{3} / 300 \mathrm{MHz}\right.$ ) (Two rotamers with an approximate ratio of 5:1 were observed. Only the major rotamer is reported.) $\delta 7.47-7.45(\mathrm{~m}, 2 \mathrm{H}), 7.38-7.20(\mathrm{~m}, 11 \mathrm{H}), 7.12(\mathrm{~d}$, $\mathrm{J}=6.9 \mathrm{~Hz}, 2 \mathrm{H}), 5.48(\mathrm{br} \mathrm{s}, 1 \mathrm{H}), 5.09(\mathrm{~s}$ and s, 2H), $4.48(\mathrm{~d}, \mathrm{~J}=14.4 \mathrm{~Hz}, 1 \mathrm{H}), 4.37$ (dd, J=10.0, 5.2 Hz, 1H), 3.86 (dd, J=11.7, $5.1 \mathrm{~Hz}, 1 \mathrm{H}), 3.78$ (d, J=14.4 Hz, 1H), 3.74 (s, 3H), 3.52 (dd, J=17.1, $3.9 \mathrm{~Hz}, 1 \mathrm{H}), 3.39$ $(\mathrm{dd}, \mathrm{J}=14.1,5.4 \mathrm{~Hz}, 1 \mathrm{H}), 3.21(\mathrm{dd}, \mathrm{J}=14.0,10.0 \mathrm{~Hz}, 1 \mathrm{H}) ;{ }^{13} \mathrm{C} \mathrm{NMR}\left(\mathrm{CDCl}_{3} / 75 \mathrm{MHz}\right) \delta 170.1,168.4$, $156.1,137.5,136.5,134.0,132.7,129.6,129.3,129.0,129.0,128.6,128.2,128.1,127.1,67.0,61.7,55.1$, 52.6, 42.6, 34.9; IR (neat/NaCl) 3406, 3339, 3059, 3020, 2947, 1734, 1664, 1451, 1245, 1208, 1046, 747, $696 \mathrm{~cm}^{-1}$; LRFAB MS (relative intensity) m/z 499 (73) $\mathrm{MLi}^{+}, 313$ (17), 160 (100); HR MS m/z calculated for $[\mathrm{M}+\mathrm{Li}]^{+} 499.1879$, found 499.1864 .

\section{2-[N-(2-Benzyloxycarbonylaminopropionyl)-N-phenylsulfanylmethylamino]-3-phenylpropionic acid methyl ester (48b):}

Compound 48b was prepared using the general procedure described above. Dry dichloromethane $(0.72 \mathrm{~mL})$, Benzenethiol $(15 \mu \mathrm{L}, 0.15 \mathrm{mmol})$, and $\mathrm{BF}_{3} \cdot \mathrm{EtO}_{2}(4.6 \mu \mathrm{L}, 0.036 \mathrm{mmol})$ were added to $31 \mathrm{mg}$ $(0.073 \mathrm{mmol})$ of N-methoxylmethylated dipeptide (46b). The crude product was chromatographed as described above to afford $33 \mathrm{mg}(89 \%)$ of product. The HPLC chromatogram of the purified material showed one major peak. ${ }^{1} \mathrm{H}$ NMR $\left(\mathrm{CDCl}_{3} / 300 \mathrm{MHz}\right)$ (Three rotamers with approximate ratios of 5:2:1 were observed. Only the major rotamer is reported.) $\delta 7.52-7.12(\mathrm{~m}, 15 \mathrm{H}), 5.46(\mathrm{~d}, \mathrm{~J}=7.5 \mathrm{~Hz}, 1 \mathrm{H}), 5.12-$ $5.05(\mathrm{~m}, 2 \mathrm{H}), 4.54\left(\mathrm{~A}\right.$ of $\left.\mathrm{AB}, \mathrm{J}_{\mathrm{AB}}=14.4 \mathrm{~Hz}, 1 \mathrm{H}\right), 4.41(\mathrm{dd}, \mathrm{J}=5.1,10.2,1 \mathrm{H}), 4.22$ (quartet of doublets, app quintet, $\mathrm{J} \approx 7 \mathrm{~Hz}, 1 \mathrm{H}), 4.04\left(\mathrm{~B}\right.$ of $\left.\mathrm{AB}, \mathrm{J}_{\mathrm{AB}}=14.4,1 \mathrm{H}\right), 3.74(\mathrm{~s}, 3 \mathrm{H}), 3.42\left(\mathrm{~A}\right.$ of $\mathrm{ABX}, \mathrm{J}_{\mathrm{AB}}=14.4 \mathrm{~Hz}, \mathrm{~J}_{\mathrm{AX}}=5.1$ $\mathrm{Hz}, 1 \mathrm{H}), 3.20\left(\mathrm{~B}\right.$ of $\left.\mathrm{ABX}, \mathrm{J}_{\mathrm{AB}}=14.1 \mathrm{~Hz}, \mathrm{~J}_{\mathrm{BX}}=10.2,1 \mathrm{H}\right), 1.17(\mathrm{~d}, \mathrm{~J}=6.9 \mathrm{~Hz}, 3 \mathrm{H}) ;{ }^{13} \mathrm{C} \mathrm{NMR}\left(\mathrm{CDCl}_{3} / 125\right.$ MHz). $\delta 172.6,170.3,155.2,137.6,136.7,133.7,132.7,129.5,129.5,128.8,128.8,128.7,128.3,128.2$, 127.2, 66.8, 61.3, 55.4, 52.5, 47.2, 35.0, 19.5; IR (neat/NaCl) 3322, 3106, 3086, 3062, 3030, 2981, 2950, 2872, 2852, 1955, 1883, 1746-1635, 1604, 1584, 1574, 1538-1418, 1353-1167, 1113, 1088, 1065, 1026, 938, 908, 847, 824, 746, $697 \mathrm{~cm}^{-1}$; LREI MS (relative intensity) m/z 397 (32) [M-SPh $]^{+}, 353$ (40), 282 (48), 231 (28), 229 (31), 192 (100), 132 (82), 91 (100); LRFAB MS (relative intensity) m/z 512 (40) $\mathrm{MLi}^{+}, 91$ (63), 89 (100); HRFAB MS m/z calculated for $[\mathrm{M}+\mathrm{Li}]^{+} 513.2036$, found 513.2030 and $514.2068\left({ }^{13} \mathrm{C}\right)$. 
2-[N-(2-Benzyloxycarbonylamino-3-phenylpropionyl)-N-phenylsulfanylmethylamino]-3phenylpropionic acid methyl ester (48c):

Compound 48c was prepared using the general procedure described above. Dry dichloromethane $(0.57 \mathrm{~mL})$, benzenethiol $(12 \mu \mathrm{L}, 0.11 \mathrm{mmol})$, and $\mathrm{BF}_{3} \cdot \mathrm{EtO}_{2}(3.6 \mu \mathrm{L}, 0.029 \mathrm{mmol})$ were added to $29 \mathrm{mg}$ $(0.057 \mathrm{mmol})$ of $\mathrm{N}$-methoxylmethylated dipeptide (46c). The crude product was chromatographed as described above to afford $31 \mathrm{mg}(91 \%)$ of product. The HPLC chromatogram of the purified material showed one major peak. ${ }^{1} \mathrm{H}$ NMR $\left(\mathrm{CDCl}_{3} / 300 \mathrm{MHz}\right) \delta 7.50-7.02(\mathrm{~m}, 20 \mathrm{H}), 5.26(\mathrm{br} \mathrm{d}, \mathrm{J}=9.0 \mathrm{~Hz}, 1 \mathrm{H})$, 5.07-4.98 (m, 2H), 4.75 (ddd, app. quartet, $\mathrm{J} \approx 7 \mathrm{~Hz}, 1 \mathrm{H}), 4.58(\mathrm{dd}, \mathrm{J}=8.7,6.6 \mathrm{~Hz}, 1 \mathrm{H}), 4.49$ (d, J=14.1 Hz, $1 \mathrm{H}), 4.36(\mathrm{~d}, \mathrm{~J}=13.8 \mathrm{~Hz}, 1 \mathrm{H}), 3.67$ and $3.53(\mathrm{~s}$ and $\mathrm{s}, 3 \mathrm{H}), 3.40(\mathrm{dd}, \mathrm{J}=14.2,6.4 \mathrm{~Hz}, 1 \mathrm{H}), 3.05-3.85(\mathrm{~m}$, $3 \mathrm{H}) ;{ }^{13} \mathrm{C} \mathrm{NMR}\left(\mathrm{CDCl}_{3} / 75 \mathrm{MHz}\right) \delta 171.9,170.4,155.5,137.5,136.3,133.2,129.7,129.5,129.4,129.2$, $129.0,128.7,128.7,128.5,128.3,128.1,127.2,127.0,67.0,60.8,54.2,52.6,52.5,39.6$, 35.3; IR (neat/NaCl) 3311, 3064, 1740, 1720, 1709, 1642, 1438, 1231, 747, $696 \mathrm{~cm}^{-1}$; LRFAB MS (relative intensity) m/z 589 (46) $\mathrm{MLi}^{+}, 313$ (16), 160 (100); HR MS m/z calculated for [M+Li] 589.2349, found 589.2332 .

General procedure for the preparation of (chloromethyl)dimethyl(2-methoxyphenyl)silane and (chloromethyl)dimethyl(2,4-methoxyphenyl)silane:

To a $250 \mathrm{~mL}$ flame-dried round bottom flask was added (mono or di-) bromoanisole (20 mmol) and dry THF $(30 \mathrm{~mL})$. The solution was cooled to $-78{ }^{\circ} \mathrm{C}$ and n-butyllithium $(9.6 \mathrm{~mL}, 1.6 \mathrm{M}$ in hexane) was added. The mixture was then stirred at $-78{ }^{\circ} \mathrm{C}$ for $30 \mathrm{~min}$ before being treated with chloro(chloromethyl)silane $(2.90 \mathrm{~mL}, 22 \mathrm{mmol})$. The resulting white suspension was stirred at room temperature for $2 \mathrm{~h}$ and then quenched with a saturated ammonium chloride solution. The layers were separated and the aqueous layer was extracted three times with ether. The combined organic layer was dried over $\mathrm{MgSO}_{4}$ and concentrated in vacuo. The crude product was chromatographed through a silica gel column using pure hexane as eluant to afford the desired monomethoxyphenyl product $(3.74 \mathrm{~g}, 87 \%)$ or the desired dimethoxyphenyl product $(4.5 \mathrm{~g}, 92 \%)$. The spectroscopic data for both chlorosilanes were consistent with those previously reported in the literature (Gotteland, J.; Guilhem, M.; Halazy, S. Syn. Commun. 1996, 26, 2928.

\section{2-\{[(Dimethylphenylsilanyl)methyl]amino\}-3-phenylpropionic acid methyl ester (50b):}

Compound 50b was prepared using the general procedure described above for the synthesis of 27. In this experiment, the crude product was chromatographed through a silica gel column using 1:4 EtOAc/hexane as eluant. The column afforded $3.3 \mathrm{~g}(68 \%)$ of the desired product. ${ }^{1} \mathrm{H} \mathrm{NMR}\left(\mathrm{CDCl}_{3} / 300\right.$ MHz) \& 7.49-7.46 (m, 2H), 7.38-7.31 (m, 3H), 7.22-7.19 (m, 3H), 7.09-7.08 (m, 2H), 3.57 (s, 3H), $3.40(\mathrm{t}$, $\mathrm{J}=7.0 \mathrm{~Hz}, 1 \mathrm{H}), 2.86(\mathrm{~d}, \mathrm{~J}=7.0 \mathrm{~Hz}, 2 \mathrm{H}), 2.26(\mathrm{~d}, \mathrm{~J}=13.5 \mathrm{~Hz}, 1 \mathrm{H}), 2.10(\mathrm{~d}, \mathrm{~J}=13.5 \mathrm{~Hz}, 1 \mathrm{H}), 0.28(\mathrm{~s}, 3 \mathrm{H}), 0.26$ $(\mathrm{s}, 3 \mathrm{H}) ;{ }^{13} \mathrm{C}$ NMR $\left(\mathrm{CDCl}_{3} / 75 \mathrm{MHz}\right) \delta 175.2,139.4,137.6,133.9,133.2,129.7,129.4,129.3,128.4,128.0$, 126.7, 66.8, 51.6, 39.3, 37.3, -3.7, -4.0; IR (neat/NaCl) 3472, 3048, 3024, 2954, 1737, 1529, 1428, 1358, $1251,1118,872,830,778,730,699 \mathrm{~cm}^{-1}$; LRFAB MS (relative intensity) m/z 334 (68) $\mathrm{MLi}^{+}, 328$ (96) $\mathrm{M}^{+}, 268(30) \mathrm{M}^{+}-\mathrm{HCOOCH}_{3}, 236(100)$; HRMS m/z calculated for $[\mathrm{M}+\mathrm{H}]^{+} 328.1733$, found 328.1733.

\section{2-\{[(Methyldiphenylsilanyl)methyl]amino\}-3-phenylpropionic acid methyl ester (50c):}

Compound 50c was prepared using the procedure described above for the synthesis of 27 . In this experiment, the crude product was chromatographed through a slica gel column using 1:5 EtOAc/hexane as eluant. The column afforded $4.4 \mathrm{~g}(75 \%)$ of the desired product. ${ }^{1} \mathrm{H}$ NMR $\left(\mathrm{CDCl}_{3} / 300 \mathrm{MHz}\right) \delta 7.61$ $7.46(\mathrm{~m}, 5 \mathrm{H}), 7.40-7.27(\mathrm{~m}, 6 \mathrm{H}), 7.25-7.17(\mathrm{~m}, 2 \mathrm{H}), 7.16-7.09(\mathrm{~m}, 2 \mathrm{H}), 3.61(\mathrm{~d}, \mathrm{~J}=0.6 \mathrm{~Hz}, 1.5 \mathrm{H}), 3.61(\mathrm{~s}$, $1.5 \mathrm{H}), 3.46(\mathrm{t}, \mathrm{J}=6.3 \mathrm{~Hz}, 1 \mathrm{H}), 2.90-2.81(\mathrm{~m}, 2 \mathrm{H}), 2.61(\mathrm{dd}, \mathrm{J}=13.5,1.5 \mathrm{~Hz}, 1 \mathrm{H}), 2.38(\mathrm{dd}, \mathrm{J}=13.5,1.5 \mathrm{~Hz}$, $1 \mathrm{H}), 0.55,0.55$ and $0.55(\mathrm{~s}, \mathrm{~s}$ and $\mathrm{s}, 3 \mathrm{H}) ;{ }^{13} \mathrm{C} \mathrm{NMR}\left(\mathrm{CDCl}_{3} / 75 \mathrm{MHz}\right) \delta 175.2,137.9,135.9,135.6,134.8$, 134.8, 129.6, 129.6, 129.3, 128.4, 128.1, 128.0, 126.6, 66.9, 51.6, 39.4, 36.2, -5.0; IR (neat/NaCl) 3068, 2951, 2788, 1737, 1589, 1428, 1253, 1170, 1114, 789, 698 $\mathrm{cm}^{-1}$; LRFAB MS (relative intensity) m/z 390 
(41) $\mathrm{MLi}^{+}, 298$ (57) $\mathrm{MLi}^{+}-\mathrm{PhCH}_{2}-\mathrm{H}, 197$ (100), 135 (68); HRMS m/z calculated for [M+H] 390.1889, found 390.1876 and 390.1881 .

2-(\{[(2-Methoxyphenyl)dimethylsilanyl]methyl $\}$ amino)-3-phenylpropionic acid methyl ester (50d):

Compound 50d was prepared using the procedure described above for the synthesis of 27 . In this experiment, the crude product was chromatographed through a slica gel column using 1:4 EtOAc/hexane as eluant. The column afforded $4.4 \mathrm{~g}(82 \%)$ of the desired product. ${ }^{1} \mathrm{H}$ NMR $\left(\mathrm{CDCl}_{3} / 300 \mathrm{MHz}\right) \delta 7.41$ $7.32(\mathrm{~m}, 2 \mathrm{H}), 7.28-7.20(\mathrm{~m}, 3 \mathrm{H}), 7.16-7.11(\mathrm{~m}, 2 \mathrm{H}), 6.94(\mathrm{t}, \mathrm{J}=7.8 \mathrm{~Hz}, 1 \mathrm{H}), 6.79(\mathrm{~d}, \mathrm{~J}=8.2 \mathrm{~Hz}, 1 \mathrm{H}), 3.71(\mathrm{~s}$, $3 \mathrm{H}), 3.61(\mathrm{~s}, 3 \mathrm{H}), 3.45(\mathrm{t}, \mathrm{J}=6.9 \mathrm{~Hz}, 1 \mathrm{H}), 2.90(\mathrm{~d}, \mathrm{~J}=6.6 \mathrm{~Hz}, 2 \mathrm{H}), 2.31(\mathrm{~d}, \mathrm{~J}=12.9 \mathrm{~Hz}, 1 \mathrm{H}), 2.19(\mathrm{~d}$, $\mathrm{J}=12.9 \mathrm{~Hz}, 1 \mathrm{H}), 0.28(\mathrm{~s}, 1.5 \mathrm{H}), 0.27(\mathrm{~s}, 4.5 \mathrm{H}) ;{ }^{13} \mathrm{C} \mathrm{NMR}\left(\mathrm{CDCl}_{3} / 75 \mathrm{MHz}\right) \delta 175.2,164.4,137.9,135.7$, $131.5,131.3,129.4,128.5,126.7,125.5,120.8,109.6,67.0,55.1,51.6,39.3,37.5,-3.4,-3.5$; IR (neat/NaCl) 2952, 1736, 1589, 1460, 1430, 1237, 1166, 1024, 840, 758, 699 $\mathrm{cm}^{-1}$; LRFAB MS (relative intensity) $\mathrm{m} / \mathrm{z} 358(70) \mathrm{MH}^{+}, 313$ (32), 250 (4) $\mathrm{M}^{+}-\mathrm{PhOCH}_{3}, 160$ (100); HRMS m/z calculated for $[\mathrm{M}+\mathrm{H}]^{+} 357.1760$, found 358.1838 and $359.1859\left({ }^{13} \mathrm{C}\right)$.

2-(\{[(2,4-Dimethoxyphenyl)dimethylsilanyl]methyl\}amino)-3-phenyl-propionic acid methyl ester (50e):

Compound 50e was prepared using the procedure described above for the synthesis of 27 . In this experiment, the crude product was chromatographed through a slica gel column using 1:3 EtOAc/hexane as eluant. The column afforded $5.3 \mathrm{~g}(91 \%)$ of the desired product. ${ }^{1} \mathrm{H}$ NMR $\left(\mathrm{CDCl}_{3} / 300 \mathrm{MHz}\right) \delta 7.28$ $7.19(\mathrm{~m}, 5 \mathrm{H}), 7.14-7.11(\mathrm{~m}, 1 \mathrm{H}), 6.49-6.46(\mathrm{~m}, 1.5 \mathrm{H}), 6.37-6.36(\mathrm{~m}, 0.5 \mathrm{H}), 3.82(\mathrm{~s}, 3 \mathrm{H}), 3.67(\mathrm{~s}, 3 \mathrm{H})$, $3.61(\mathrm{~s}, 3 \mathrm{H}), 3.44(\mathrm{t}, \mathrm{J}=7.0 \mathrm{~Hz}, 1 \mathrm{H}), 2.89(\mathrm{dd}, \mathrm{J}=7.0,2.0 \mathrm{~Hz}, 2 \mathrm{H}), 2.27(\mathrm{~d}, \mathrm{~J}=13.0 \mathrm{~Hz}, 1 \mathrm{H}), 2.15(\mathrm{~d}$, $\mathrm{J}=13.0 \mathrm{~Hz}, 1 \mathrm{H}), 0.24(\mathrm{~s}, 3 \mathrm{H}), 0.24(\mathrm{~s}, 3 \mathrm{H}) ;{ }^{13} \mathrm{C} \mathrm{NMR}\left(\mathrm{CDCl}_{3} / 75 \mathrm{MHz}\right) \delta 175.3,165.8,162.8,137.9,136.6$, 129.4, 128.5, 126.6, 1004.8, 97.8, 67.0, 55.4, 55.1, 51.6, 39.3, 37.6, -3.3, -3.4; IR (neat/NaCl) 2953, 2834, 1736, 1597, 1462, 1405, 1301, 1246, 1208, 1157, 1089, 1033, 839, 700 $\mathrm{cm}^{-1}$; LRFAB MS (relative intensity) m/z 394 (63) $\mathrm{MLi}^{+}, 313$ (11), 250 (100) $\mathrm{M}^{+}-2 \mathrm{Li}-(\mathrm{MeO})_{2} \mathrm{Ph}, 165$ (67); HRMS m/z calculated for $[\mathrm{M}+\mathrm{Li}]^{+}$394.2026, found 394.2037 and $395.2063\left({ }^{13} \mathrm{C}\right)$.

2-\{(2-tert-Butoxycarbonylaminoacetyl)-[(dimethylphenylsilanyl)methyl]amino\}-3-phenyl-propionic acid methyl ester (49b):

Compound 49b was prepared using the procedure described above for the synthesis of 30a. In this experiment, the crude product was chromatographed through a silica gel column using 1:3 EtOAc/hexane as eluant. The column afforded $3.4 \mathrm{~g}(71 \%)$ of the desired product. ${ }^{1} \mathrm{H} \mathrm{NMR}\left(\mathrm{CDCl}_{3} / 300\right.$ $\mathrm{MHz}$ ) (two main rotamers with approximately 1:1 ratio were observed) $\delta 7.60-7.50(\mathrm{~m}, 1 \mathrm{H}), 7.42-7.18$ $(\mathrm{m}, 7 \mathrm{H}), 7.12-7.10(\mathrm{~m}, 1 \mathrm{H}), 7.07-7.00(\mathrm{~m}, 1 \mathrm{H}), 5.52$ and $5.35(\mathrm{br} \mathrm{s}$ and br s, $1 \mathrm{H}), 4.44(\mathrm{dd}, \mathrm{J}=9.0,5.4 \mathrm{~Hz}$, $0.5 \mathrm{H}), 3.96-3.85(\mathrm{~m}, 1 \mathrm{H}), 3.70$ and $3.65(\mathrm{~s}$ and $\mathrm{s}, 3 \mathrm{H}), 3.54(\mathrm{t}, \mathrm{J}=7.6 \mathrm{~Hz}, 0.5 \mathrm{H}), 3.31(\mathrm{dd}, \mathrm{J}=16.4,3.4 \mathrm{~Hz}$, $0.5 \mathrm{H}), 3.37-3.20(\mathrm{~m}, 2 \mathrm{H}), 2.95(\mathrm{dd}, \mathrm{J}=14.2,9.15 \mathrm{~Hz}, 0.5 \mathrm{H}), 2.90\left(\mathrm{~A}\right.$ of $\left.\mathrm{AB}, \mathrm{J}_{\mathrm{AB}}=14.7 \mathrm{~Hz}, 0.5 \mathrm{H}\right), 2.77(\mathrm{~B}$ of $\left.\mathrm{AB}, \mathrm{J}_{\mathrm{AB}}=14.7 \mathrm{~Hz}, 0.5 \mathrm{H}\right), 2.74\left(\mathrm{~A}^{\prime}\right.$ of $\left.\mathrm{A}^{\prime} \mathrm{B}^{\prime}, \mathrm{J}_{\mathrm{A}^{\prime} \mathrm{B}}=16.5 \mathrm{~Hz}, 0.5 \mathrm{H}\right), 1.92\left(\mathrm{~B}^{\prime}\right.$ of $\mathrm{A}^{\prime} \mathrm{B}^{\prime}, \mathrm{J}_{\mathrm{A}^{\prime} \mathrm{B}}=16.5 \mathrm{~Hz}, 0.5 \mathrm{H}$ ), 1.45 and 1.42 (s and s, 9H), 0.40, $0.38(\mathrm{~s}$ and s, $3 \mathrm{H}), 0.30$ and $0.24(\mathrm{~s}$, and $\mathrm{s}, 3 \mathrm{H}) ;{ }^{13} \mathrm{C} \mathrm{NMR}\left(\mathrm{CDCl}_{3} / 75\right.$ $\mathrm{MHz}) \delta 170.0,170.0,168.5,167.6,155.9,137.9,136.2,136.1,133.8,133.7,130.0,129.2,129.0,128.7$, $128.2,127.8,127.3,126.8,79.5,64.3,61.3,52.6,52.1,42.7,41.9,40.4,35.5,34.3,28.4,28.4,-2.0,-2.3$, 3.5, -4.4; IR (neat/NaCl) 3421, 2976, 1743, 1718, 1654, 1496, 1465, 1366, 1249, 1169, 1113, 840, 700 $\mathrm{cm}^{-}$ ${ }^{1}$; LRFAB MS (relative intensity) $\mathrm{m} / \mathrm{z} 485$ (14) $\mathrm{MLi}^{+}, 429$ (9) $\mathrm{MLi}^{+}-\mathrm{C}_{4} \mathrm{H}_{8}, 407$ (17) $\mathrm{MLi}^{+}-\mathrm{PhH}, 351$ (100) $\mathrm{MLi}^{+}-\mathrm{PhMeSi}=\mathrm{CH}_{2}, 307$ (26), 154 (27), 135 (98); HRMS m/z calculated for $[\mathrm{M}+\mathrm{H}]^{+}$485.2472, found 485.2452 and 485.2452.

\section{2-\{(2-tert-Butoxycarbonylaminoacetyl)-[(methyldiphenylsilanyl)methyl]amino\}-3-phenyl-propionic acid methyl ester (49c):}

Compound 49c was prepared using the procedure described above for the synthesis of 30a. In this experiment, the crude product was chromatographed through a silica gel column using a gradient 
elution from 1:3 EtOAc/hexane to 1:1.5 EtOAc/hexane. The column afforded $3.3 \mathrm{~g}(60 \%)$ of the desired product. ${ }^{1} \mathrm{H} \mathrm{NMR}\left(\mathrm{CDCl}_{3} / 300 \mathrm{MHz}\right)$ (two main rotamers with approximately $1: 1$ ratio were observed) $\delta$ 7.58-7.19 $(\mathrm{m}, 13 \mathrm{H}), 7.10-7.08(\mathrm{~d}, \mathrm{~J}=1.5 \mathrm{~Hz}, 1 \mathrm{H}), 7.08-6.98(\mathrm{~m}, 1 \mathrm{H}), 5.50$ and $5.28($ br s, and br s, $1 \mathrm{H})$, $4.43(\mathrm{dd}, \mathrm{J}=9.0,5.7 \mathrm{~Hz}, 0.5 \mathrm{H}), 3.92(\mathrm{td}, \mathrm{J}=17.9,4.0 \mathrm{~Hz}, 1 \mathrm{H}), 3.72-3.59(\mathrm{~m}, 1 \mathrm{H}), 3.63$ and $3.49(\mathrm{~s}$ and $\mathrm{s}$, $3 \mathrm{H}), 3.52-3.38(\mathrm{~m}, 1 \mathrm{H}), 3.33-3.15(\mathrm{~m}, 2 \mathrm{H}), 3.05(\mathrm{~d}, \mathrm{~J}=16.5 \mathrm{~Hz}, 0.5 \mathrm{H}), 2.96(\mathrm{dd}, \mathrm{J}=14.2,9.2 \mathrm{~Hz}, 0.5 \mathrm{H})$, $2.23(\mathrm{~d}, \mathrm{~J}=16.5 \mathrm{~Hz}, 0.5 \mathrm{H}), 1.45$ and $1.41(\mathrm{~s}$ and s, $9 \mathrm{H}), 0.69$ and $0.59(\mathrm{~s}$ and $\mathrm{s}, 3 \mathrm{H}) ;{ }^{13} \mathrm{C} \mathrm{NMR}\left(\mathrm{CDCl}_{3} / 75\right.$ MHz) $\delta 169.9,168.7,167.8,138.0,137.6,136.2,134.8,134.8,134.5,133.9,130.4,130.1,129.3,129.3$, 129.2, 129.1, 129.0, 128.8, 128.3, 128.3, 27.9, 127.4, 127.0, 79.6, 64.2, 61.4, 52.7, 52.1, 42.8, 42.1, 39.2, 35.6, 34.5, 34.0, 28.5, 28.5, -3.5, -5.6; IR (neat/NaCl) 3421, 2977, 1743, 1713, 1650, 1496, 1428, 1456, 1250, 1168, 793, 734, $700 \mathrm{~cm}^{-1}$; LRFAB MS (relative intensity) m/z 553 (50) $\mathrm{MLi}^{+}, 453$ (100) $\mathrm{MLi}^{+}-$ Boc $+\mathrm{H}, 197$ (60) , 105 (26); HRMS m/z calculated for $[\mathrm{M}+\mathrm{H}]^{+}$553.2710, found 553.2696 and 553.2697.

\section{2-((2-tert-Butoxycarbonylaminoacetyl)-\{[(2-methoxyphenyl)dimethylsilanyl]methyl $\}$ amino)-3- phenylpropionic acid methyl ester (49d):}

Compound 49d was prepared using the procedure described above for the synthesis of 30a. In this experiment, the crude product was chromatographed through a silica gel column using 1:3.5 EtOAc/hexane as eluant. The column afforded $4.1 \mathrm{~g}(80 \%)$ of the desired product. ${ }^{1} \mathrm{H} \mathrm{NMR}\left(\mathrm{CDCl}_{3} / 300\right.$ $\mathrm{MHz}$ ) (two main rotamers with approximately 3:1 ratio were observed) $\delta 7.39-7.29(\mathrm{~m}, 1 \mathrm{H}), 7.28-7.11$ $(\mathrm{m}, 4 \mathrm{H}), 7.09-7.04(\mathrm{~m}, 2 \mathrm{H}), 6.96-6.90(\mathrm{~m}, 1 \mathrm{H}), 6.88-6.75(\mathrm{~m}, 1 \mathrm{H}), 5.56$ and $5.38(\mathrm{br} \mathrm{s}$ and br s, 1H), 4.38$4.35(\mathrm{~m}, 0.1 \mathrm{H}), 3.95-3.52(\mathrm{~m}, 2.9 \mathrm{H}), 3.81$ and $3.76(\mathrm{~s}$ and $\mathrm{s}, 3 \mathrm{H}), 3.64$ and $3.56(\mathrm{~s}$ and $\mathrm{s}, 3 \mathrm{H}), 3.39-3.18$ $(\mathrm{m}, 2 \mathrm{H}), 2.84(\mathrm{~d}, \mathrm{~J}=16.2 \mathrm{~Hz}, 1 \mathrm{H}), 2.12(\mathrm{~d}, \mathrm{~J}=16.2 \mathrm{~Hz}, 1 \mathrm{H}), 1.44$ and 1.40 (s and s, 9H), 0.35, 0.27 and 0.25 (s, s and s, 6H); ${ }^{13} \mathrm{C} \mathrm{NMR}\left(\mathrm{CDCl}_{3} / 75 \mathrm{MHz}\right) \delta 170.1,169.9,168.4,167.5,163.8,155.6,138.1,136.4$, 135.6, 135.0, 131.8, 130.8, 129.2, 129.0, 128.9, 128.6, 127.4, 127.2, 126.6, 123.4, 120.6, 120.5, 109.6, 109.4, 79.3, 64.5, 61.4, 55.0, 52.4, 52.0, 42.7, 42.0, 39.9, 35.4, 34.3, 28.4, 28.3, -2.2, -2.7, -3.5, -3.7; IR (neat $/ \mathrm{NaCl}) 3421,2953,1742,1713,1651,1597,1464,1247,1208,1157,1088,1031,840,703 \mathrm{~cm}^{-1}$; LRFAB MS (relative intensity) m/z 515 (8) $\mathrm{MLi}^{+}, 499$ (19), 473 (5), 443 (19), 407 (29) $\mathrm{MLi}^{+}-\mathrm{PhOCH}_{3}$, 351 (100), 307 (36), 165 (34), 135 (71); HRMS m/z calculated for $[\mathrm{M}+\mathrm{H}]^{+} 515.2577$, found 515.2563 and 515.2575 .

\section{2-((2-tert-Butoxycarbonylaminoacetyl)-\{[(2,4-dimethoxyphenyl)dimethylsilanyl]methyl $\}$ amino)-3-} phenylpropionic acid methyl ester (49e):

Compound 49 was prepared using the procedure described above for the synthesis of 30a. In this experiment, the crude product was chromatographed through a silica gel column using 1:3 EtOAc/hexane as eluant. The column afforded $4.4 \mathrm{~g}(81 \%)$ of the desired product. ${ }^{1} \mathrm{H}$ NMR $\left(\mathrm{CDCl}_{3} / 300 \mathrm{MHz}\right)$ (two main rotamers with approximately $2: 1$ ratio observed) $\delta$ 7.32-7.11 $(\mathrm{m}, 5 \mathrm{H}), 7.08-7.05(\mathrm{~m}, 1 \mathrm{H}), 6.53-6.37$ $(\mathrm{m}, 2 \mathrm{H}), 5.58$ and $5.42(\mathrm{br} \mathrm{s}$ and $\mathrm{br} \mathrm{s}, 1 \mathrm{H}), 4.46-4.38(\mathrm{~m}, 0.2 \mathrm{H}), 3.96-3.81(\mathrm{~m}, 2.8 \mathrm{H}), 3.80,3.79,3.75$, $3.66(\mathrm{~s}, \mathrm{~s}, \mathrm{~s}$ and s, 9H), 3.78-3.55 (m, 2H), 3.36-3.20 (m, 2H), $2.82(\mathrm{~d}, \mathrm{~J}=16.3 \mathrm{~Hz}, 1 \mathrm{H}), 2.11(\mathrm{~d}, \mathrm{~J}=16.3 \mathrm{~Hz}$, $1 \mathrm{H}), 1.46,1.45,1.42$ amd1.41 (s, s, s and s, 9H), 0.34, 0.30, 0.27, $0.23(\mathrm{~s}, \mathrm{~s}, \mathrm{~s}$ and $\mathrm{s}, 6 \mathrm{H}) ;{ }^{13} \mathrm{C} \mathrm{NMR}$ $\left(\mathrm{CDCl}_{3} / 75 \mathrm{MHz}\right) \delta 170.4,167.6,165.4,163.4,161.0,155.8,138.3,136.8,130.1,129.4,129.2,129.1$, 129.1, 128.7, 126.8, 114.8, 106.3, 104.9, 100.6, 97.9, 97.8, 79.5, 64.7, 55.4, 55.2, 52.2, 42.9, 40.1, 34.5, 28.6, 28.5, -3.3, -3.4; IR (neat/NaCl) 2975, 1744, 1711, 1648, 1465, 1235, 1165, 841, 758, $702 \mathrm{~cm}^{-1}$; LRFAB MS (relative intensity) m/z 551 (31) $\mathrm{MLi}^{+}, 529$ (8), 501 (6), 473 (16) $\mathrm{MLi}^{+}-\mathrm{PhH}, 451$ (70) $\mathrm{MLi}^{+}$Boc-H, 351 (85), 165 (100), 133 (87); HRMS m/z calculated for [M+Li] 551.2765, found 551.2776, and 551.2751.

General procedure for the chemical oxidation of silylated peptide derivatives $30 \mathrm{a}$ and $49 \mathrm{~b}$-e with ceric ammonium nitrate (formation of 31a):

A $100 \mathrm{~mL}$ oven-dried round bottom flask was charged with the silylated dipeptide $(0.5 \mathrm{mmol})$ and a mixture of anhydrous methanol and $\mathrm{CH}_{2} \mathrm{Cl}_{2}\left(25 \mathrm{~mL}\right.$ ) (the best ratio of $\mathrm{MeOH}$ to $\mathrm{CH}_{2} \mathrm{Cl}_{2}$ for substrates 49d and 49e is $15 \%$ and $20 \%$ respectively). The resulting solution was stirred and ceric 
ammonium nitrate $(1.1 \mathrm{~g}, 2 \mathrm{mmol})$ added under argon. The reaction mixture was then allowed to stir at room temperature (or $-40{ }^{\circ} \mathrm{C}, 0{ }^{\circ} \mathrm{C}$ ) for $30 \mathrm{~min}$ to $12 \mathrm{~h}$ (see Table 3 in the text for reaction times and temperatures) and quenched with $1 \mathrm{~mL} 30 \% \mathrm{Na}_{2} \mathrm{SO}_{3}$ solution. The resulting mixture was stirred for 15 min until two clear layers were formed. The layers were then separated. The organic layer was washed with water $(2 \times 20 \mathrm{~mL})$ and the combined aqueous layer was extracted with dichloromethane $(2 \times 10 \mathrm{~mL})$. The combined organic solution was dried over $\mathrm{MgSO}_{4}$ and concentrated in vacuo. The crude product was chromatographed through a silica gel column using 1:1 hexane/EtOAc as eluant to obtain the oxidation product 62. The yields for different substrates are listed in Table 3. In all cases, the spectral data for the product were consistent with that reported above for compound $\mathbf{3 1 a}$.

\section{2-[(3-Benzyloxy-2-tert-butoxycarbonylaminopropionyl)trimethylsilanylmethylamino]-3-phenyl- propionic acid methyl ester (51a):}

Compound 51a was synthesized above in connection with Scheme 12 (the converstion of amino acid $\mathbf{2 7}$ to the dipeptide equivalent $\mathbf{2 8}$ ).

\section{2-((3-Benzyloxy-2-tert-butoxycarbonylaminopropionyl)-\{[(2-methoxyphenyl)dimethylsilanyl]- methyl \}amino)-3-phenyl-propionic acid methyl ester (51b):}

Compound 51b was prepared using the procedure described above for the synthesis of 30a. The crude product was chromatographed through a silica gel column using 1:4 EtOAc/hexane as eluant. The column afforded $0.91 \mathrm{~g} \mathrm{(36 \% )}$ of the desired product (the yield was not optimized). ${ }^{1} \mathrm{H} \mathrm{NMR}\left(\mathrm{CDCl}_{3} / 300\right.$ $\mathrm{MHz}$ ) (two main rotamers with approximately $2: 1$ ratio observed) $\delta 7.38-7.04(\mathrm{~m}, 12 \mathrm{H}), 6.98-6.89(\mathrm{~m}$, $1 \mathrm{H}), 6.81(\mathrm{dd}, \mathrm{J}=17.7,8.1 \mathrm{~Hz}, 1 \mathrm{H}), 5.45(\mathrm{~d}, \mathrm{~J}=8.1 \mathrm{~Hz}, 0.67 \mathrm{H}), 5.25(\mathrm{~d}, \mathrm{~J}=7.8 \mathrm{~Hz}, 0.33 \mathrm{H}), 5.00-4.89(\mathrm{~m}$, $0.33 \mathrm{H}), 4.87-4.79(\mathrm{~m}, 0.67 \mathrm{H}), 4.58(\mathrm{br} \mathrm{s}, 2 \mathrm{H}), 4.46-4.30(\mathrm{~m}, 1 \mathrm{H}), 3.80,3.72,3.65$ and $3.52(\mathrm{~s}, \mathrm{~s}, \mathrm{~s}$ and $\mathrm{s}$, $6 \mathrm{H}), 3.79-3.50(\mathrm{~m}, 2 \mathrm{H}), 3.36-2.87(\mathrm{~m}, 3.5 \mathrm{H}), 2.30(\mathrm{~d}, \mathrm{~J}=16.2 \mathrm{~Hz}, 0.5 \mathrm{H}), 1.44$ and 1.41 (s and $\mathrm{s}, 9 \mathrm{H}), 0.40$, $0.35,0.32$ and $0.29(\mathrm{~s}, \mathrm{~s}, \mathrm{~s}$, and $\mathrm{s}, 6 \mathrm{H}) ;{ }^{13} \mathrm{C} \mathrm{NMR}\left(\mathrm{CDCl}_{3} / 75 \mathrm{MHz}\right) \delta 170.6,170.3,170.3,169.5,164.0$, $163.9,155.0,155.0,138.6,138.0,137.7,137.0,135.8,135.1,131.8,131.0,129.5,129.4,129.2$, 129.0, $128.7,128.5,128.5,128.2,127.9,127.7,127.6,126.9,126.6,123.9,120.7,109.7,109.5,79.5,73.5,73.4$, $71.1,65.2,62.1,55.1,55.1,52.4,52.0,50.5,49.6,41.5,36.1,34.7,28.5,28.4,-2.3,-2.5,-3.9,-4.1$; IR (neat $/ \mathrm{NaCl}) 3432,3064,3030,2977,1745,1714,1634,1588,1496,1455,1431,1236,1173,1064,1025$, 844, 735, $700 \mathrm{~cm}^{-1}$; LRFAB MS (relative intensity) $\mathrm{m} / \mathrm{z} 641$ (68) $\mathrm{MLi}^{+}, 541$ (50) $\mathrm{M}^{+}$-Boc+H, 471 (12), 363 (7), 278 (4), 135 (100); HRMS m/z calculated for [M+Li] ${ }^{+} 641.3234$, found 641.3216 and 642.3246 $\left({ }^{13} \mathrm{C}\right)$.

\section{2-((3-Benzyloxy-2-tert-butoxycarbonylaminopropionyl)-\{[(2,4-dimethoxyphenyl)dimethylsilanyl $]-$ methyl\}-amino)-3-phenyl-propionic acid methyl ester (51c):}

Compound 51c was prepared using the procedure described above for the synthesis of 30a. The crude product was chromatographed through a silica gel column using an eluant of 1:4 EtOAc/hexane as eluant. The column afforded $1.04 \mathrm{~g}(39 \%)$ of the desired product (yield was not optimized). ${ }^{1} \mathrm{H}$ NMR $\left(\mathrm{CDCl}_{3} / 300 \mathrm{MHz}\right)$ (two main rotamers with approximately 3:1 ratio were observed) $\delta 7.34-7.07(\mathrm{~m}, 11 \mathrm{H})$, 6.53-6.50 (m, 2H), $5.45(\mathrm{~d}, \mathrm{~J}=8.4 \mathrm{~Hz}, 0.75 \mathrm{H}), 5.26(\mathrm{~d}, \mathrm{~J}=8.7 \mathrm{~Hz}, 0.25 \mathrm{H}), 4.98$ (br t, J=5.0Hz, 0.25H), 4.88$4.80(\mathrm{~m}, 0.75 \mathrm{H}), 4.58(\mathrm{~s}, 1.5 \mathrm{H}), 4.45(\mathrm{~d}, \mathrm{~J}=11.7 \mathrm{~Hz}, 0.25 \mathrm{H}), 4.32(\mathrm{~d}, \mathrm{~J}=11.7 \mathrm{~Hz}, 0.25 \mathrm{H}), 3.82,3.81,3.80$ and $3.79(\mathrm{~s}, \mathrm{~s}, \mathrm{~s}$ and $\mathrm{s}, 6 \mathrm{H}), 3.80-3.74(\mathrm{~m}, 1 \mathrm{H}), 3.70,3.66,3.62$ and $3.60(\mathrm{~s}, \mathrm{~s}, \mathrm{~s}$ and $\mathrm{s}, 6 \mathrm{H}), 3.54-3.46(\mathrm{~m}$, $2 \mathrm{H}), 3.32-3.14(\mathrm{~m}, 1.75 \mathrm{H}), 3.28\left(\mathrm{~A}\right.$ of $\left.\mathrm{AB}, \mathrm{J}_{\mathrm{AB}}=16.5 \mathrm{~Hz}, 0.75 \mathrm{H}\right), 2.93-2.80(\mathrm{~m}, 0.75 \mathrm{H}), 2.26(\mathrm{~B}$ of $\mathrm{AB}$, $\left.\mathrm{J}_{\mathrm{AB}}=16.2 \mathrm{~Hz}, 0.75 \mathrm{H}\right), 1.44$ and $1.40(\mathrm{~s}$ and $\mathrm{s}, 9 \mathrm{H}), 0.37,0.36,0.32,0.29$ and $0.24(\mathrm{~s}, \mathrm{~s}, \mathrm{~s}, \mathrm{~s}$ and $\mathrm{s}, 6 \mathrm{H}) ;{ }^{13} \mathrm{C}$ $\mathrm{NMR}\left(\mathrm{CDCl}_{3} / 75 \mathrm{MHz}\right) \delta 169.8,168.9,164.9,162.6,154.5,138.0,137.5,136.4,136.2,135.4,135.0$, 129.0, 128.8, 128.2, 128.0, 127.9, 127.7, 127.4, 127.2, 127.1, 126.3, 126.0, 114.6, 104.2, 97.3, 97.1, 78.9, $72.8,70.5,64.6,54.8,54.6,54.5,51.9,51.5,49.9,41.0,34.2,27.9,27.9,-2.8,-3.0,-4.5,-4.5$; IR (neat/NaCl) 3334, 2978, 1744, 1712, 1659, 1497, 1454, 1240, 1168, 1089, 913, 738, $700 \mathrm{~cm}^{-1}$; LRFAB MS (relative intensity) m/z 671 (79) $\mathrm{MLi}^{+}, 571$ (37) $\mathrm{MLi}^{+}-\mathrm{Boc}+\mathrm{H}, 471$ (17), 165 (100); HRMS m/z calculated for $[\mathrm{M}+\mathrm{Li}]^{+} 671.3340$, found 671.3329 and $672.3364\left({ }^{13} \mathrm{C}\right)$. 


\section{Procedure for the chemical amide oxidation with $\mathbf{N}$ - $\alpha$-silylated peptide derivatives 51 a-c using ceric}

ammonium nitrate):

In each case, a $100 \mathrm{~mL}$ oven-dried round bottom flask was charged with silylated dipeptide $(0.5$ mmol) and a mixture of anhydrous methanol and $\mathrm{CH}_{2} \mathrm{Cl}_{2}(25 \mathrm{~mL})$. The best ratio of $\mathrm{MeOH} / \mathrm{CH}_{2} \mathrm{Cl}_{2}$ for substrate 51b and 51c is $15 \%$ and $20 \%$ respectively. For the trimethylsilyl electroauxiliary case (51a) the overall yield of oxidation product $\mathbf{5 2}$ was never higher that 15\% regardless of the conditions. In each case, the resulting solution was stirred at room temperature and ceric ammonium nitrate $(1.1 \mathrm{~g}, 2 \mathrm{mmol})$ added under argon. The reaction mixture was then allowed to stir at room temperature (or $0{ }^{\circ} \mathrm{C}$ ). In the case of 51b the reaction was allowed to stand for roughly $90 \mathrm{~min}$ at room temp in order to afford a $72 \%$ yield of the methoxylated product 52. In the case of 51c, a room temperature reaction that stood for approximately $15 \mathrm{~min}$ led to a $70 \%$ yield of product while a $0{ }^{\circ} \mathrm{C}$ reaction allowed to stand for 35 min led to an $80 \%$ isolated yield of product. After each reaction was complete, it was quenched with $1 \mathrm{~mL} 30 \% \mathrm{Na}_{2} \mathrm{SO}_{3}$ solution. The resulting mixture was stirred for $15 \mathrm{~min}$ until two clear layers were formed. The layers were then separated. The organic layer was washed with water $(2 \times 20 \mathrm{~mL})$ and the combined aqueous layer was extracted with dichloromethane $(2 \times 10 \mathrm{~mL})$. The combined organic solution was dried over $\mathrm{MgSO}_{4}$ and concentrated in vacuo. The crude product was chromatographed through a silica gel column using 1:1 hexane/EtOAc as eluant to obtain the oxidation product $\mathbf{5 2}$.

\section{2-[(3-Benzyloxy-2-tert-butoxycarbonylamino-propionyl)-methoxymethyl-amino]-3-phenyl- propionic acid methyl ester (52):}

${ }^{1} \mathrm{H}$ NMR $\left(\mathrm{CDCl}_{3} / 300 \mathrm{MHz}\right) \delta$ 7.36-7.19 (m, 10H), $5.32(\mathrm{~d}, \mathrm{~J}=8.7 \mathrm{~Hz}, 1 \mathrm{H}), 4.87(\mathrm{dd}, \mathrm{J}=14.7$, $6.3 \mathrm{~Hz}, 1 \mathrm{H}), 4.67(\mathrm{~d}, \mathrm{~J}=11.4 \mathrm{~Hz}, 1 \mathrm{H}), 4.53(\mathrm{br} \mathrm{s}, 2 \mathrm{H}), 4.39(\mathrm{dd}, \mathrm{J}=9.6,5.4 \mathrm{~Hz}, 1 \mathrm{H}), 4.13(\mathrm{~d}, \mathrm{~J}=11.4 \mathrm{~Hz}, 1 \mathrm{H})$, $3.69(\mathrm{~s}, 3 \mathrm{H}), 3.67-3.53(\mathrm{~m}, 2 \mathrm{H}), 3.41(\mathrm{dd}, \mathrm{J}=14.2,5.2 \mathrm{~Hz}, 1 \mathrm{H}), 3.23(\mathrm{~s}, 3 \mathrm{H}), 3.17(\mathrm{dd}, \mathrm{J}=9.4,4.7 \mathrm{~Hz}, 1 \mathrm{H})$, $1.42(\mathrm{~s}, 9 \mathrm{H}) ;{ }^{13} \mathrm{C} \mathrm{NMR}\left(\mathrm{CDCl}_{3} / 75 \mathrm{MHz}\right) \delta 171.5,170.8,155.2,138.0,137.7,129.4,128.7,128.6,128.5$, 127.9, 127.7, 126.8, 80.0, 79.7, 73.4, 71.0, 60.8, 55.7, 52.4, 50.6, 35.2, 28.4; IR (neat/NaCl) 3432, 2954, 1744, 1712, 1639, 1597, 1495, 1455, 1248, 1209, 1157, 1088, 839, 749, $700 \mathrm{~cm}^{-1}$; LRFAB MS (relative intensity) $\mathrm{m} / \mathrm{z} 507$ (100) $\mathrm{MLi}^{+}, 451(16) \mathrm{M}^{+}-\mathrm{C}_{4} \mathrm{H}_{8}, 407$ (26) $\mathrm{MLi}^{+}-\mathrm{Boc}+\mathrm{H}, 285$ (5), 160 (63); HRMS m/z calculated for $[\mathrm{M}+\mathrm{Li}]^{+}$507.2683, found 507.2687 and $508.2728\left({ }^{13} \mathrm{C}\right)$.

\section{2-(\{2-[2-((2-Benzyloxycarbonylaminoacetyl)-\{[(2,4-dimethoxyphenyl)dimethylsilanyl]methyl $\}-$ amino)-3-phenylpropionylamino] acetyl\}trimethylsilanylmethylamino)-3-phenylpropionic acid methyl ester (53):}

The tetrapeptide substrate $\mathbf{5 3}$ was made from two of the dipeptide substrates made earlier using the coupling procedure described below. The carboxylic acid needed for the reaction was obtained by hydrolyzing $\mathrm{Cbz}-\mathrm{Gly}-\left[\mathrm{N}-\mathrm{CH}_{2}\right.$-(2,4-dimethoxyphenyldimethylsilyl)]-Phe-OMe (made in a fashion identical to 49e except for the use of $\mathrm{Cbz}$ protected glycine instead of the t-Boc protected glycine) using 2 equiv of $\mathrm{LiOH}$ in a 2:1 mixture of methanol to water. The reaction was stirred at $0{ }^{\circ} \mathrm{C}$ for $3 \mathrm{~h}$ and then room temperature for $12 \mathrm{~h}$. The spectral data for Cbz-Gly-[N-CH$-(2,4-d i m e t h o x y p h e n y l d i m e t h y l s i l y l)]-$ Phe-OH were as follows: ${ }^{1} \mathrm{H}$ NMR $\left(\mathrm{CDCl}_{3} / 300 \mathrm{MHz}\right)$ (two main rotamers with approximately 2:1 ratio observed) $\delta$ 7.36-7.06 (m, 11H), 6.54-6.37 (m, 2H), 5.96-5.94 (m, 1H), 5.15-5.06 (m, 2H), $4.68(\mathrm{~s}, 1.5 \mathrm{H})$, 3.99-3.78 $(\mathrm{m}, 1 \mathrm{H}), 3.81,3.80,3.78,3.77,3.76$ and $3.75(\mathrm{~s}, \mathrm{~s}, \mathrm{~s}, \mathrm{~s}, \mathrm{~s}$ and $\mathrm{s}, 4 \mathrm{H}), 3.86-3.65(\mathrm{~m}, 2 \mathrm{H}), 3.55(\mathrm{~s}$, $0.5 \mathrm{H}), 3.31-3.23(\mathrm{~m}, 2 \mathrm{H}), 2.88(\mathrm{~d}, \mathrm{~J}=17.0 \mathrm{~Hz}, 1 \mathrm{H}), 2.09(\mathrm{~d}, \mathrm{~J}=17.0 \mathrm{~Hz}, 1 \mathrm{H}), 0.37,0.34,0.29$ and $0.27(\mathrm{~s}, \mathrm{~s}$, $\mathrm{s}$ and $\mathrm{s}, 6 \mathrm{H}) ;{ }^{13} \mathrm{C} \mathrm{NMR}\left(\mathrm{CDCl}_{3} / 75 \mathrm{MHz}\right) \delta 168.5,165.4,163.4,161.0,156.5,141.0,137.9,136.8,136.7$, $136.6,130.0,129.3,129.2,129.0,128.8,128.7,128.6,128.2,128.1,127.8,126.9,114.5,106.3,105.1$, 100.6, 66.9, 65.8, 65.4, 56.1, 55.5, 55.4, 55.2, 43.3, 40.9, 34.4, -3.1, -3.4, -4.2; IR (neat/NaCl) 3416, 3031, $2956,1727,1648,1604,1494,1455,1288,1256,1210,1152,1051,840,752,700 \mathrm{~cm}^{-1}$; LRFAB MS (relative intensity) $\mathrm{m} / \mathrm{z} 577$ (14) $\mathrm{MLi}^{+}, 539$ (4) $\mathrm{M}^{+}-\mathrm{CH}_{3} \mathrm{O}, 427$ (17) $\mathrm{MLi}^{+}-\mathrm{CbzNH}, 390$ (4), 334 (26), 194 (35), 165 (100), 121 (29); HRMS m/z calculated for $[\mathrm{M}+\mathrm{Li}]^{+}$571.2452, found 571.2455, and $572.2487\left({ }^{13} \mathrm{C}\right)$. 
The amine needed for the coupling reaction was obtained by deprotecting the t-Boc group from $\mathrm{t}-$ Boc-Gly-(N-CH2-TMS)-Phe-OMe 30a by treatment with $5 \mathrm{~mL}$ (for $2 \mathrm{mmol}$ of substrate) of a saturated aqueous $\mathrm{HCl}$ solution in $15 \mathrm{~mL}$ of ehtyl acetate. The reaction was allowed to stir at room temperature for $30 \mathrm{~min}$. The amine was carried forward into the coupling reaction.

Once these two transformations were complete, a $250 \mathrm{~mL}$ oven-dried round bottom flask was

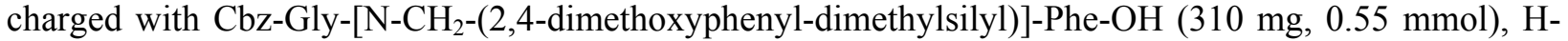
Gly-(N-CH2-TMS)-Phe-OMe (480 mg, $1.5 \mathrm{mmol})$, HBTU (237 mg, $0.6 \mathrm{mmol})$, HOAT (10.4 mg, 0.075 $\mathrm{mmol}), 2,4,6$-collidine $(264 \mu \mathrm{L}, 2.0 \mathrm{mmol})$ and DMF $(20 \mathrm{~mL})$. The resulting solution was allowed to stir at room temperature for $16 \mathrm{~h}$ and then quenched with water. The layers were separated and the aqueous layer was extracted with EtOAc three times. The combined organic layer was dried over $\mathrm{MgSO}_{4}$ and concentrated in vacuo. The crude product was chromatographed through a silica gel column using a gradient elution from 1:3 EtOAc/hexane to 1:1.5 EtOAc/hexane. The column afforded $237 \mathrm{mg}$ (49\% for 2 steps of the deesterification and coupling reactions) of the desired product. ${ }^{1} \mathrm{H} \mathrm{NMR}\left(\mathrm{CDCl}_{3} / 300 \mathrm{MHz}\right)$ $\delta$ 7.38-7.00 (m, 16H), 6.47-6.39 (m, 2H), $5.85(\mathrm{~d}, \mathrm{~J}=16.2 \mathrm{~Hz}, 0.75 \mathrm{H}), 5.60(\mathrm{~s}, 0.25 \mathrm{H}), 5.13(\mathrm{~s}, 2 \mathrm{H}), 4.44-$ $4.40(\mathrm{~m}, 0.5 \mathrm{H}), 4.23-3.86(\mathrm{~m}, 3.5 \mathrm{H}), 3.81,3.79,3.73$ and $3.72(\mathrm{~s}, \mathrm{~s}, \mathrm{~s}$ and $\mathrm{s}, 9 \mathrm{H}), 3.34-3.21(\mathrm{~m}, 4 \mathrm{H}), 3.09-$ $2.86(\mathrm{~m}, 2 \mathrm{H}), 2.74(\mathrm{dd}, \mathrm{J}=14.2,6.4 \mathrm{~Hz}, 0.5 \mathrm{H}), 2.70-2.51(\mathrm{~m}, 1.5 \mathrm{H}), 2.41-2.27(\mathrm{~m}, 1 \mathrm{H}), 1.82-1.72(\mathrm{~m}, 1 \mathrm{H})$, $0.37,0.35,0.32,0.30,0.29$ and $0.28(\mathrm{~s}, \mathrm{~s}, \mathrm{~s}, \mathrm{~s}, \mathrm{~s}$ and $\mathrm{s}, 6 \mathrm{H}), 0.04,0.03$ and $0.02(\mathrm{~s}, \mathrm{~s}$ and $\mathrm{s}, 9 \mathrm{H}) ;{ }^{13} \mathrm{C} \mathrm{NMR}$ $\left(\mathrm{CDCl}_{3} / 75 \mathrm{MHz}\right) \delta 170.4,170.2,169.9,169.6,168.9,167.0,165.6,163.4,156.3,138.1,137.8,137.6$, $137.2,136.7,136.4,136.2,129.4,129.3,129.2,128.9,128.8,128.7,128.2,128.1,127.5,127.9,126.9$, $105,1,104.8,97.9,67.1,66.9,65.9,65.7,64.6,61.3,55.4,55.2,52.8,52.4,43.7,42.1,41.3,40.9,39.6$, 36.0, 35.7, 34.6, 34.4, 30.5, -0.4, -1.8, -3.0; IR (neat/NaCl) 3423, 2952, 1743, 1648, 1495, 1250, 1152 , 1052, 846, $700 \mathrm{~cm}^{-1}$; LRFAB MS (relative intensity) m/z 875 (6) $\mathrm{MLi}^{+}, 313$ (31), 160 (100); HRMS m/z calculated for $[\mathrm{M}+\mathrm{Li}]^{+} 875.4059$, found 875.4053 and $876.4090\left({ }^{13} \mathrm{C}\right)$.

\section{2-[(2-\{2-[(2-Benzyloxycarbonylaminoacetyl)methoxymethylamino]-3-phenylpropionylamino $\}-$ acetyl)trimethylsilanylmethylamino]-3-phenylpropionic acid methyl ester (54):}

A $100 \mathrm{~mL}$ oven-dried round bottom flask was charged with compound $\mathbf{5 3}$ (170 mg, $0.20 \mathrm{mmol})$ and a mixture of anhydrous methanol and $\mathrm{CH}_{2} \mathrm{Cl}_{2}(9.8 \mathrm{~mL}, 1: 7 \mathrm{v} / \mathrm{v})$. The resulting solution was stirred at room temperature (or $-40{ }^{\circ} \mathrm{C}$ ) and ceric ammonium nitrate $(429 \mathrm{mg}, 0.78 \mathrm{mmol}$ ) was added under argon. The reaction mixture was allowed to stir at room temperature for $25 \mathrm{~min}$ (or $-40{ }^{\circ} \mathrm{C}$ for $95 \mathrm{~min}$ ) and then quenched with $1 \mathrm{~mL} 30 \% \mathrm{Na}_{2} \mathrm{SO}_{3}$ solution. The mixture was stirred for 5 min until two clear layers were formed. The layers were then separated. The organic layer was washed with water $(2 \times 10 \mathrm{~mL})$ and the combined aqueous layer was extracted with dichloromethane $(2 \times 10 \mathrm{~mL})$. The combined organic extract was dried over $\mathrm{MgSO}_{4}$ and concentrated in vacuo. The crude product was chromatographed through a silica gel column using a gradient elution from 1:2 EtOAc/hexane to 1:1 EtOAc/hexane to afford $93 \mathrm{mg}$ $(68 \%)$ of the desired product for the room temperature condition or $101 \mathrm{mg}(74 \%)$ of the desired product for the $-40{ }^{\circ} \mathrm{C}$ condition. ${ }^{1} \mathrm{H} \mathrm{NMR}\left(\mathrm{CDCl}_{3} / 300 \mathrm{MHz}\right) \delta 7.70(\mathrm{br} \mathrm{s}, 1 \mathrm{H}), 7.38-7.11(\mathrm{~m}, 15 \mathrm{H}), 5.74-5.49$ $(\mathrm{m}, 1 \mathrm{H}), 5.14(\mathrm{~d}, \mathrm{~J}=3.3 \mathrm{~Hz}, 2 \mathrm{H}), 4.87-4.78(\mathrm{~m}, 0.67 \mathrm{H}), 4.72-4.62(\mathrm{~m}, 0.33 \mathrm{H}), 4.58-4.43(\mathrm{~m}, 1 \mathrm{H}), 4.36-$ $4.28(\mathrm{~m}, 0.5 \mathrm{H}), 4.22-4.02(\mathrm{~m}, 2 \mathrm{H}), 4.00-3.80(\mathrm{~m}, 1.5 \mathrm{H}), 3.48-3.36(\mathrm{~m}, 2 \mathrm{H}), 3.77,3.75$ and $3.73(\mathrm{~s}, \mathrm{~s}$ and $\mathrm{s}, 3 \mathrm{H}), 3.48-2.98(\mathrm{~m}, 3 \mathrm{H}), 3.33,3.32,3.30$ and $3.29(\mathrm{~s}, \mathrm{~s}, \mathrm{~s}$ and $\mathrm{s}, 3 \mathrm{H}), 2.76-2.53(\mathrm{~m}, 1.67 \mathrm{H}), 2.51-2.28$ $(\mathrm{m}, 0.33 \mathrm{H}), 1.82(\mathrm{dd}, \mathrm{J}=16.5,4.8 \mathrm{~Hz}, 1 \mathrm{H}), 0.14,0.06,0.03$ and $0.02(\mathrm{~s}, \mathrm{~s}, \mathrm{~s}$ and $\mathrm{s}, 9 \mathrm{H}) ;{ }^{13} \mathrm{C}$ NMR $\left(\mathrm{CDCl}_{3} / 75 \mathrm{MHz}\right) \delta 170.4,170.2,169.9,169.6,169.4,167.7,167.0,156.4,143.3,138.0,137.7,137.6$, $136.6,136.2$, 129.3, 129.2, 129.2, 128.9, 128.8, 128.7, 128.2, 128.2, 127.5, 127.0, 126.9, 116.6, 116.2, $78.4,67.1,64.6,62.0,61.4,55.9,52.8,52.4,42.9,42.0,41.3,40.9,36.0,35.7,35.2,25.0,34.8,34.6,30.5$, 27.4, 20.2, -0.5, -1.2, -1.8; IR (neat/NaCl) 3423, 2952, 2280, 2119, 1742, 1649, 1526, 1454, 1248, 857, $701 \mathrm{~cm}^{-1}$; LRFAB MS (relative intensity) m/z 711 (3) $\mathrm{MLi}^{+}, 313$ (20), 160 (100); HRMS m/z calculated for $[\mathrm{M}+\mathrm{Li}]^{+} 711.3401$, found 711.3385 and $712.3413\left({ }^{13} \mathrm{C}\right)$.

2-(\{[(4-Dimethylaminophenyl)dimethylsilanyl]methyl\}amino)-3-phenylpropionic acid methyl ester (57): 
A $250 \mathrm{~mL}$ round bottom flask containing (chloromethyl)[4-(dimethylamino)phenyl]dimethylsilane $\mathrm{e}^{26}(1.89 \mathrm{~g} 8.29 \mathrm{mmol})$ was charged with $\mathrm{KI}(1.38 \mathrm{~g}, 8.29 \mathrm{mmol})$, diisopropylamine $(4.7 \mathrm{~mL}, 33 \mathrm{mmol})$, and the hydrochloride salt of L-Phenylalanine methyl ester (3.58 g, $16.6 \mathrm{mmol})$ and subsequently filled with argon. Anhydrous DMF $(50 \mathrm{~mL})$ was then added and the resulting suspension was heated to $85^{\circ} \mathrm{C}$ for $42 \mathrm{~h}$. The reaction solution was next quenched with brine and extracted four times with diethyl ether. The ethereal extracts were combined and washed once with brine, dried over $\mathrm{MgSO}_{4}$, and concentrated in vacuo. The crude material was then chromatographed through a silica gel column using an eluant of 15\%-20\% EtOAc in hexane to afford $1.43 \mathrm{~g} \mathrm{(47 \% )}$ of the desired product as an pale yellow oil. ${ }^{1} \mathrm{H}$ NMR $\left(\mathrm{CDCl}_{3} / 300 \mathrm{MHz}\right) \delta 7.36$ (ddd, J=9Hz, 2.2Hz, 2.2Hz, 2H), 7.28-7.10(m, 5H), $6.71(\mathrm{ddd}, \mathrm{J}=8.7 \mathrm{~Hz}, 2.0 \mathrm{~Hz}, 2.0 \mathrm{~Hz}, 2 \mathrm{H}), 3.60(\mathrm{~s}, 3 \mathrm{H}), 3.428(\mathrm{t}, \mathrm{J}=7.2 \mathrm{~Hz}, 1 \mathrm{H}), 2.95(\mathrm{~s}, 6 \mathrm{H}), 2.88$ (dd, $\mathrm{J}=7.1 \mathrm{~Hz}, 3.1 \mathrm{~Hz}, 2 \mathrm{H}), 2.16(\mathrm{dd}, \mathrm{J}=51 \mathrm{~Hz}, 13 \mathrm{~Hz}, 2 \mathrm{H}), 1.28($ broad s, $1 \mathrm{H}), 0.248$ and $0.227(\mathrm{~s}$ and s, $6 \mathrm{H}) ;{ }^{13} \mathrm{C}$ NMR $\left(\mathrm{CDCl}_{3} / 75 \mathrm{MHz}\right) \delta 175.5,151.5,138.0,135.1,129.4,128.6,126.7,122.7,112.2,67.0,51.5,40.6$, 39.6, 37.9, -3.4; IR (NMR sample/NaCl) 3325, 3083, 3026, 2950, 2893, 2850, 2794, 1736, 1598, 1543, 1514, 1495, 1454, 1444, 1355, 1275, 1246, 1222, 1206, 1169, 1112, 1061, 1006, 983, 946, 913, 839, 805, $747,700,526 \mathrm{~cm}^{-1}$; LRFAB MS (relative intensity) m/z M+ 370 (2), $\mathrm{M}^{+}$-benzyl, 279 (8), SilylAryl ${ }^{+}, 178$ (100); HRMS m/z calculated for $\mathrm{M}^{+} 370.2077$, found $370.2090, \mathrm{~m} / \mathrm{z}$ calculated for $\mathrm{M}^{+}+1372.2110$, found 371.2091

2-((2-tert-Butoxycarbonylaminoacetyl)-\{[(4-dimethylaminophenyl)dimethylsilanyl]methyl\}-amino)3-phenylpropionic acid methyl ester (58):

A $250 \mathrm{~mL}$ round bottom flask was charged with $\mathrm{N}$-(tert-butoxycarbonyl)glycine $(0.085 \mathrm{~g}, 0.49$ $\mathrm{mmol})$, NMM (55 uL, $0.49 \mathrm{mmol})$, isobutylchloroformate $(85 \mathrm{uL}, 0.65 \mathrm{mmol})$ and $\mathrm{CH}_{2} \mathrm{Cl}_{2}(30 \mathrm{~mL})$. The resulting solution was allowed to stir at $0{ }^{\circ} \mathrm{C}$ for $120 \mathrm{~min}$. The $\mathrm{N}-\alpha$-silylated phenylalanine methyl ester $(0.32 \mathrm{mmol})$ was dissolved in $\mathrm{CH}_{2} \mathrm{Cl}_{2}(10 \mathrm{~mL})$ and cannulated into the reaction mixture above. An additional $20 \mathrm{~mL}$ of $\mathrm{CH}_{2} \mathrm{Cl}_{2}$ was used to ensure the complete transfer. The mixture was then warmed to room temperature and stirred for $12 \mathrm{~h}$. The reaction was quenched with water and the layers were separated. Then the organic layer was washed with water and dried over $\mathrm{MgSO}_{4}$. After filtration, the filtrate was concentrated in vacuo and the crude product chromatographed through a silica gel column using an eluant of $10 \%$ EtOAc in hexane to afford $125 \mathrm{mg}(73 \%)$ of the desired product as an oil. ${ }^{1} \mathrm{H}$ NMR $\left(\mathrm{CD}_{3} \mathrm{CN} / 300 \mathrm{MHz}\right)$ (two main rotamers with approximately $2: 1$ ratio observed) $\delta 7.41(\mathrm{~d}, \mathrm{~J}=8.7 \mathrm{~Hz}$, $1 \mathrm{H}), 7.34-7.19(\mathrm{~m}, 5 \mathrm{H}), 7.11(\mathrm{~d}, \mathrm{~J}=8.1 \mathrm{~Hz}, 1 \mathrm{H}), 6.75(\mathrm{~d}, \mathrm{~J}=8.4 \mathrm{~Hz}, 1 \mathrm{H}), 6.74(\mathrm{~d}, \mathrm{~J}=8.7 \mathrm{~Hz}, 1 \mathrm{H}), 5.42$ and $5.32(\mathrm{br} \mathrm{s}$ and br s, $1 \mathrm{H}), 4.68-4.60(\mathrm{~m}, 0.3 \mathrm{H}), 3.95-3.52(\mathrm{~m}, 3 \mathrm{H}), 3.69$ and 3.63 (s and $\mathrm{s}, 3 \mathrm{H}), 3.29-3.00$ $(\mathrm{m}, 2 \mathrm{H}), 3.36-3.20(\mathrm{~m}, 2 \mathrm{H}), 2.93(\mathrm{~s}, 6 \mathrm{H}), 2.80(\mathrm{~d}, \mathrm{~J}=14.7 \mathrm{~Hz}, 1 \mathrm{H}), 2.66(\mathrm{~d}, \mathrm{~J}=14.4 \mathrm{~Hz}, 1 \mathrm{H}), 1.44$, and 1.40 (s and s, 9H), 0.34, 0.27, 0.24, $0.20(\mathrm{~s}, \mathrm{~s}, \mathrm{~s}$ and s, $6 \mathrm{H}) ;{ }^{13} \mathrm{C} \mathrm{NMR}\left(\mathrm{CD}_{3} \mathrm{CN} / 75 \mathrm{MHz}\right) \delta 171.6,170.3,169.3$, 153.0, 152.6, 139.8, 138.5, 136.2, 130.8, 129.8, 128.3, 127.8, 122.1, 113.3, 80.1, 72.1, 65.1, 62.5, 53.5, $52.7,43.7,43.0,42.1,41.7,40.8,36.8,36.1,35.4,29.0,19.6,-1.0,-1.3,-2.6,-3.6$, IR (NMR sample/ $\mathrm{NaCl}) 3418,3084,3063,2953,2809,1743,1715,1648,1597,1514,1496,1465,1392,1365$, $1276,1248,1228,1170,1111,1082,1052,1029,1005,946,868,840,808,754,703,636 \mathrm{~cm}^{-1}$.

\section{Solid Phase Peptide Synthesis of Compounds 59 and 60:}

A $100 \mathrm{~mL}$ oven-dried round bottom flask was charged with Merrifield resin (2.0 g, $9.4 \mathrm{mmol}), 2-$ mercaptoethanol $(5.27 \mathrm{~mL}, 75.2 \mathrm{mmol})$, potassium carbonate $(2.6 \mathrm{~g}, 19 \mathrm{mmol})$ and dry DMF $(44 \mathrm{~mL})$. The resulting suspension was stirred at $60{ }^{\circ} \mathrm{C}$ for $4 \mathrm{~h}$ and then at room temperature for $20 \mathrm{~h}$. The reaction mixture was then filtered through a glass filter. The resin was washed with $\mathrm{H}_{2} \mathrm{O}(5 \mathrm{x}), \mathrm{DMF}(2 \mathrm{x}), \mathrm{H}_{2} \mathrm{O}$ (2x), MeOH (2x), DCM (2x), MeOH- $\mathrm{H}_{2} \mathrm{O}(1: 1)(2 \mathrm{x})$ and DCM (5x) and dried in vacuo to afford $\sim 2 \mathrm{~g}$ of white resin $\mathbf{A}$.

To the suspension of the resin $\mathbf{A}(\sim 2 \mathrm{~g})$ in dichloromethane $(110 \mathrm{~mL})$ was added MCPBA $(13.1 \mathrm{~g}$, $77 \%, 58.4 \mathrm{mmol})$ in portions at $0{ }^{\circ} \mathrm{C}$. When the addition was complete, the resulting solution was allowed to stir for $20 \mathrm{~h}$ at room temperature and then filtered through a glass filter. The resin was washed with $\operatorname{DCM}(2 \mathrm{x}), \mathrm{MeOH}(5 \mathrm{x})$ and DCM (5x) and dried in vacuo to afford $\sim 2.5 \mathrm{~g}$ of white resin $\mathbf{B}$. 
To a $100 \mathrm{~mL}$ oven-dried round bottom flask was added the Cbz-Gly- $\left[\mathrm{N}-\mathrm{CH}_{2}-(2,4-\right.$ dimethoxyphenyldimethylsilyl)]-Phe-OH dipeptide acid $(1.4 \mathrm{mmol})$ made above for the synthesis of 53, HBTU (586 mg, $1.5 \mathrm{mmol})$, HOAT (25.5 mg, $0.18 \mathrm{mmol}), 2,4,6$-collidine (330 $\mu \mathrm{L}, 2.5 \mathrm{mmol})$ and DMF $(24 \mathrm{~mL})$. The resulting solution was stirred for $15 \mathrm{~min}$ and the resin $\mathbf{B}(186 \mathrm{mg}, \sim 0.7 \mathrm{mmol})$ added. The reaction mixture was allowed to stir at room temperature for $18 \mathrm{~h}$ and then filtered through a glass filter. The resin was washed with DCM (2x), DMF (5x) and DCM (5x) and dried in vacuo to afford yellow white resin $\mathbf{C}$.

The resin $\mathbf{C}$ was suspended in $20 \mathrm{~mL}$ of benzene in a $100 \mathrm{~mL}$ round bottom flask. A mixture of $\mathrm{Ac}_{2} \mathrm{O}$ and $\mathrm{HCOOH}(654 \mu \mathrm{L} / 1.29 \mathrm{~mL}, 9: 20, \mathrm{w} / \mathrm{w})$ was then added to the above suspension. The reaction mixture was allowed to stir at room temperature for $16 \mathrm{~h}$ and then filtered through a glass filter. The resin was washed with MeOH (3x), DMF (3x) and DCM (5x) and dried in vacuo to afford $260 \mathrm{mg}$ yellow white resin D (59).

The resin $\mathbf{D}(107 \mathrm{mg}, \sim 0.045 \mathrm{mmol})$ was suspended in a mixture of $\mathrm{CH}_{2} \mathrm{Cl}_{2}$ and $\mathrm{MeOH}(1.9$ $\mathrm{mL} / 0.34 \mathrm{~mL}, 7: 1)$. The resulting suspension was stirred and CAN (107 $\mathrm{mg}, 0.20 \mathrm{mmol}$ ) added under argon. The reaction mixture was allowed to stir at room temperature for $40 \mathrm{~min}$ and then filtered through a glass filter. The resin was washed with $\mathrm{MeOH}(3 \mathrm{x}), \mathrm{DMF}(3 \mathrm{x})$ and $\mathrm{DCM}(5 \mathrm{x})$ and dried in vacuo to afford $94 \mathrm{mg}$ yellow white resin $\mathbf{E}$.

To a $100 \mathrm{~mL}$ oven-dried round bottom flask was added resin $\mathbf{E}(94 \mathrm{mg})$, allylsilane (144 $\mu \mathrm{L}, 0.90$ $\mathrm{mmol})$ and ether $(2 \mathrm{~mL})$. The resulting suspension was stirred and $\mathrm{BF}_{3} \mathrm{Et}_{2} \mathrm{O}(2 \mu \mathrm{L}, 0.016 \mathrm{mmol})$ added under argon. The reaction mixture was allowed to stir at room temperature for $6 \mathrm{~h}$ and then filtered through a glass filter. The resin was washed with $\mathrm{MeOH}(3 \mathrm{x}), \mathrm{CH}_{2} \mathrm{Cl}_{2}(5 \mathrm{x})$ and dried in vacuo to afford a yellow white resin. This procedure was repeated for one more time and $96 \mathrm{mg}$ yellow white resin $\mathbf{F}$ was obtained (60).

The resin $\mathbf{F}$ was treated with a mixture of $\mathrm{NaOH}$ solution $(4 \mathrm{~N}, 1 \mathrm{~mL})$, dioxane $(30 \mathrm{~mL})$ and water $(9 \mathrm{~mL})$ in a $100 \mathrm{~mL}$ round bottom flask. The resulting suspension was allowed to stir at room temperature for $1 \mathrm{~min}$ and quickly filtered through a glass filter into a $\mathrm{HCl}$ solution $(1 \mathrm{~N}, 4 \mathrm{~mL})$. The resin was washed with ether (2x), EtOAc (2x) and DCM (5x). The filtrate was concentrated under reduced pressure. The obtained crude product was dissolved in EtOAc and washed with sat. sodium carbonate solution twice. The aqueous solution was combined and acidified with $\mathrm{HCl}$ solution (1N) until the $\mathrm{pH}=3.0$. The acidic solution was then extracted with ether three times and the combined ether solution was dried and concentrated in vacuo. The obtained crude product $(12.7 \mathrm{mg})$ was clean by ${ }^{1} \mathrm{H}$ NMR. The crude product can also be chromatographed through a silica gel column. The spectral data are given below.

For comparison, a portion of resin $\mathbf{D}$ is used for the cleavage directly. Similar procedure for the cleavage of resin $\mathbf{F}$ was used. $57 \mathrm{mg}$ resin $\mathbf{D}$ afforded $14 \mathrm{mg}$ the cleaved silylated dipeptide acid indicating that the oxidation, allylsilane additions steps went in a combined $66 \%$ yield.

\section{2-[(2-Benzyloxycarbonylaminoacetyl)but-3-enylamino]-3-phenylpropionic acid:}

${ }^{1} \mathrm{H}$ NMR $\left(\mathrm{CDCl}_{3} / 300 \mathrm{MHz}\right) \delta$ 7.41-7.12 (m, 10H), 6.16 and $6.00(\mathrm{br}$ s and br s, $1 \mathrm{H}), 5.84-5.54(\mathrm{~m}, 1 \mathrm{H})$, 5.09-4.96 (m, 3.5H), 4.70 (br s, 0.5H), 4.22-4.03 (m, 1H), 3.96-3.78 (m, 2H), 3.56-3.34 (m, 2H), 3.28$3.05(\mathrm{~m}, 1 \mathrm{H}), 2.84-2.75(\mathrm{~m}, 0.25 \mathrm{H}), 2.79-2.33(\mathrm{~m}, 1.75 \mathrm{H}), 2.19-2.04(\mathrm{~m}, 1 \mathrm{H}) ;{ }^{13} \mathrm{C} \mathrm{NMR}\left(\mathrm{CDCl}_{3} / 75 \mathrm{MHz}\right)$ $\delta 173.6,169.2,164.7,156.6,137.9,136.6,134.4,134.2$, 133.9, 130.1, 129.3, 129.0, 128.9, 128.6, 128.2, $128.1,127.8,127.2,127.0,118.0,118.0,67.1,63.8,49.3,44.2,44.1,42.9,37.3,34.5,32.5,32.3,31.8$; IR (neat $/ \mathrm{NaCl}) 3416,3064,3030,2939,1724,1658,1497,1454,1252,1215,1051,1000,920,736,701 \mathrm{~cm}^{-}$ ${ }^{1}$; LRFAB MS (relative intensity) $\mathrm{m} / \mathrm{z} 423$ (36) $\mathrm{MLi}^{+}, 315$ (22) $\mathrm{M}^{+}-\mathrm{PhCH}_{2} \mathrm{O}, 91$ (100); HRMS m/z calculated for $[\mathrm{M}+2 \mathrm{Li}-\mathrm{H}]^{+} 423.2084$, found 423.2067 , and $424.2100\left({ }^{13} \mathrm{C}\right)$. 
